

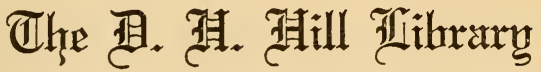

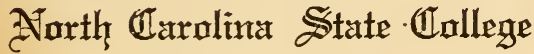

$$
\begin{gathered}
\text { SB405 } \\
\text { H39 }
\end{gathered}
$$


Date Due

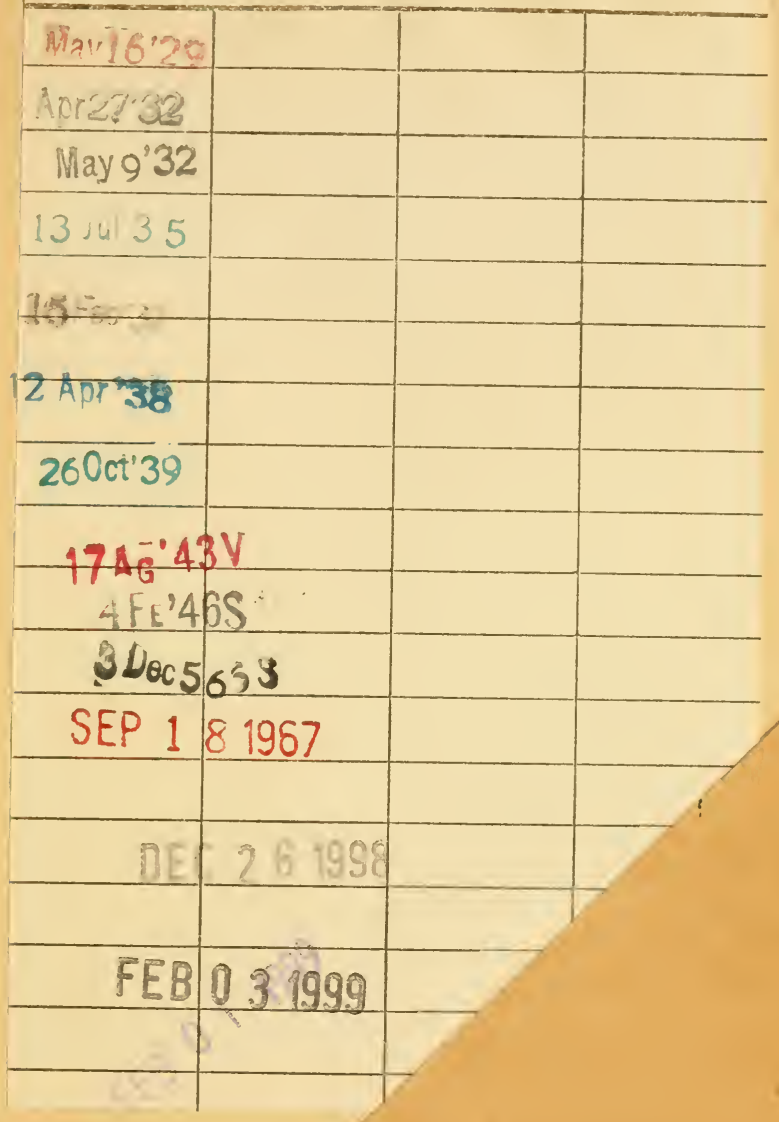





\section{The Gold Mine in the Front Yard and How to Work It}

SHOWING HOW MILLIONS OF DOLLARS

CAN BE ADDED TO THE VALUE

OF PRAIRIE FARMS

$$
\begin{aligned}
& \text { By C. S. HARRISON } \\
& \text { YORK, NEBRASKA }
\end{aligned}
$$

President of the Nebraska Park of

Forestry Society

\section{LIBRARY.}

Division of Horticulture,

N. C. Dep't of Agriculture. 
COPYRIGHTFD 1905

BY

Webe Publinhing Co. 


\section{INDEX.}

Introduction

Beauty is wealth-The mission of beauty.

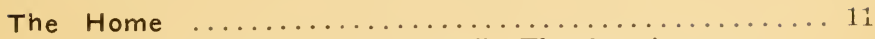

"There's no place like home"-The boys' room.

The Discovery of Beautiful Gems............... 16

The Concord Grape-The Wealthy Apple-Carnations -Paeonies, etc.

The Preparation of the Ground and the Preparation of

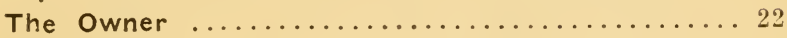

Intelligence of the plant and tree worid.

Don't Be Stingy

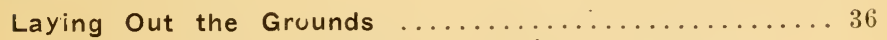

Kinds of trees and shrubbery and arrangement.

Hints and Suggestions-Selecting Trees and Shrubs.... 42

Raising plants from seed-Dogs and flowers.

Planting For Foliage Effect. .

Trees of silver foliage-Golden foliage-Purple foliage -Planting for Autumn effect.

The Lilac

The Persians-Emodi-Oblata-Jafan-Tree Lilacs, etc.

The Viburnum, or snowball............... 74

Other shrubs of value.

The Syringa, or Philadelphus $\ldots \ldots \ldots \ldots \ldots \ldots \ldots . \ldots 1$

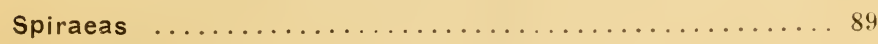

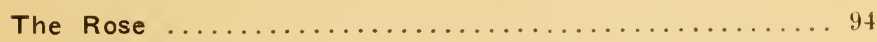

Japanese Roses-Climbing Roses-The Hybrids or Perpetuals-Preparing roses for winter. 
The Lonicera, or Honeysuckle..........................

Bush or Tree Honeysuckles-Planting a group-Propagation-Climbing Honeysuckles.

Perennial Flowers

Tulips-Yuccas-The Filamentosa-The Iris-The Golden Glow-Sunflowers.

Columbines

How to grow them-Delphiniums-The Lily-Time to plant-The Gaillardia-Oriental Poppy-Phloxes.

The Paeony

Classification-Propagation-Dividing the rootsPlanting for flowers-Raising from roots-Propagation by grafting-Raising from seed-Care of seed and planting-Hardiness-Thoroughbred flowers-Changes of soil and climate-Mistakes and mixtures-Difficulties-Retarding for spring selling-Late blooming-Nonblooming PaeoniesCutting from newly planted roots-Paeonies and insects-Diseases-Freaks, etc.

List of Some of The Leading Paeonies...............219

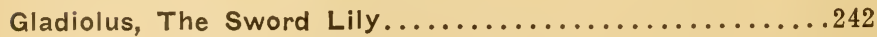

Propagation -Flowers - Forcing - Cannas - Raising from seed-The Dahlia-Propagation-Varieties, etc. 


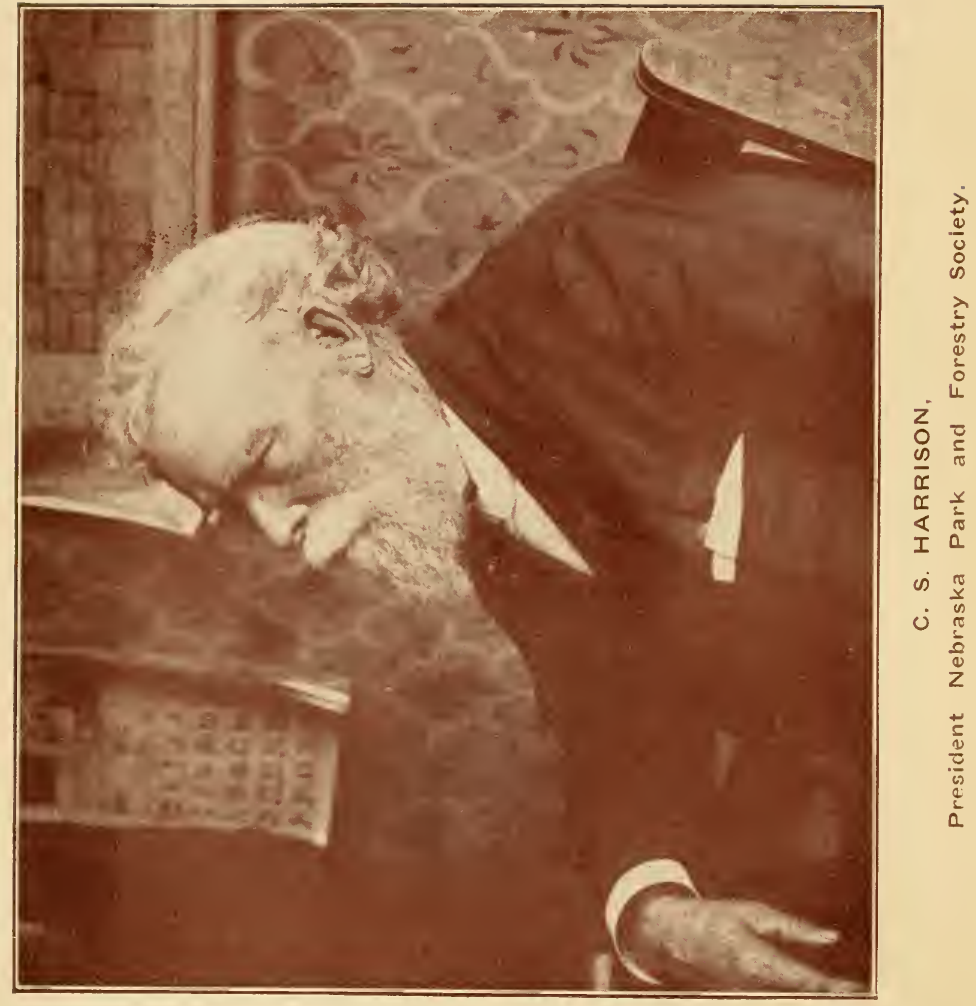




\section{LISRAEY \\ Division of Horticulare, \\ N. C. Dep't of Agriculture.}

\section{INTRODUCTION.}

Often gold is found when least suspected. Miners for a generation roamed over the Cripple Creek hills, and did not dream of the millions beneath their feet. The shepherds of Australia led their flocks over pastures paved with gold and did not know it.

A poor rancher in the mountains found nuggets of gold in the crop of a turkey, and found whence they came and soon struck his millions.

But these are rare cases. Often I have known men to trudge over the mountains for years and endure all manner of privations and grow gray before they find wealth.

But every farmer has a gold mine in his front yard, where, least suspected, there are riches. Generation follows generation and the case is rare where these mines are worked as they should be.

It is generally supposed that the money is all in the back yard, the barn, the granary and the farm, and yet the richest deposits are at the front; and every acre there is worth $\$ 1,000$ at least, as we shall see.

BEAUTY IS WEALTH.

There are priceless values outside dollars and cents. What does the rich man do? Does he put all his 
gains where they will bring back so much annual interest in cold cash? He does far better. There are more beautiful things in this life than greenbacks, silver and gold. The man gets a piece of land. A landscape gardener lays it out, then he has it planted to the choicest trees, shrubs and flowers. These are well cared for, and that piece of brown earth soon derelops into a beautiful estate-and that is wealth.

That plat of ground, of little value in itself, becomes a garden of delight. As the years go by it grows more and more beautiful-the joy of the owner and the delight of all who pass by.

Now please tell me why the western farmer cannot be rich. He has better land than the eastern man who buys a worn-out field, and then pays $\$ 10$ a cord for manure besides the hauling. The farmer has plenty of manure in his yard. Trees and flowers will grow for him as well as for others. Go to the experiment stations, and you will see what vast numbers of things there are which do well all over the West.

The farmer's wife belongs to the noblest race on earth. How much of patience, fortitude and hard work she has displayed in the homebuilding. Heaven help him if his sons and daughters are not of more worth than many of the children of the rich who live in a band box and must be fed with a spoon.

Farmers complain that their children do not like the farm, and as soon as they can they will leave it. What wonder! I knew of a man worth $\$ 75,000$, with a 
large farm well stocked-not a carpet on the floor-not a rocking chair in the house-no books, magazines or pictures-not a tree in the yard-not a shrub or flower. It was grind, grind, grind for dollars from early morning till late at night. The three daughter's who might have been ornaments to society were lured away to lives of shame. The five boys ran away and all but one became vagabonds. You do not want to raise a family of boors - awkward and ill at ease in society. You want them to be educated and refined. Surround them with refining influences; let them assoeiate with beautiful things. Give them a taste of the real luxuries and entertainments of life. Make the home so attractive that it will be the dearest spot on earth.

My thoughts revert to the home of my friend, T. C. Thurlow, of West Newbury, Mass. His grandson is the tenth generation born on the old place. Every tree has a history. One Fourth of July we took dinner under a fine old elm his grandfather planted. Back of the house is an artificial grove of spruce. The rows are like columns in some grand cathedral. The tops have woven a eanopy of green that shuts out the sun. The family are troubled with weak lungs. A few years ago he planted some little white pines and they are now a forest filling the air with healing. In front of the house are thousands of the finest of paeonies, and yonder such a field of glorious phloxes. There are silver robed trees from the Rockies. Ever- 
greens and deciduous trees gathered from different parts of the earth. Everywhere there are things of beauty. 'No wonder the children dread to leave home and rejoice when they can get back again.

Take it all around, and no investment will pay better than your gold mine in your front yard. "Well," says one, "I don't know how to work it. I don't know anything about horticulture." We thought perhaps that was the case, and so this book is written in the hope that it will develop the immense amount of wealth and beauty now idle, or existing only in thought.

Let us outline this matter. We visit a fine estate in Massachusetts. There is a marvelous group of trees dressed in silver and sapphire. Their sheen is like soft moonlight lingering among the branches. Offer the man $\$ 100$ apiece for them. He would not take twice that. You buy those same trees of silvery hue for $\$ 2.00$ each; then see them grow. They will do as well in Minnesota as in Massachusetts. Each little tree will be ambitious to work out that $\$ 100$ for you; and it will be worth as much to you and your family as to any one.

A little boy once planted a quarter, and a few days after dug it up to see if it had sprouted. Another little fellow who loved his grandma dearly moved with his parents to a far Western home. He was terribly homesick. How he did long for the kind arms and the dear old face! One day his mother found him planting a photograph in the garden. It was the picture of the dear old lady. He burst into tears and said: "I 
was plantin' danma so she would grow and I could have her adin." Poor little fellow! Silver and photos can't grow, but trees can.

I saw a beautiful lilac tree twenty years old. It was thirty inches around and thirty feet high and all that splendid crown was a mass of fragrant bloom. Would $\$ 100$ buy it? Yet for $\$ 1.00$ you buy the same kind of a tree, which is as hardy and thrifty as our native ash and which in its native mountains of Japan is a foot through and fifty feet high. Professor Green has them growing on the University grounds. There is one to match it - the Chinese tree lilac with charming foliage and drooping branches.

What a vast array of flowering shrubs. Besides 130 kinds of lilacs we have a splendid list of syringas, spiræas, viburnums, and many others.

Take the perennials. What a noble family-phloxes blooming from June to November.

Get a dozen of them and this book will tell you how to swell the number to a thousand so you can have a field of splendor.

Plant a few paeonies and soon you have hundreds.

There are the columbines which have robbed the rainbow of all its colors and woven them into bouquets fit for kings.

Think of the enjoyment you will have. When you are tired with your day's work just take a vacation on your front porch, and any day from spring till the hard frosts of autumn there will be a procession of beauty on gorgeous dress parade before you. 
If there were such a park as you might have ten miles away you would hitch the team to the carriage, and take your whole family to see it. Why don't you have a park of your own and make your farm a sort of Mecca to the lovers of nature?

Good old Mother Nature. What a heartache she has had all these years because she could not get at you and go to work for you.

She has a plan for fixing up, and just beside you in the unseen she has a vision of loveliness which she would like to make a substantial reality. She is ready. to open the door into fairyland and let you see just what is waiting for you.

You read these lines and ask, "Is this possible for" me?" Yes! Now won't you fix up? That neglected piece of ground is too valuable for rooting pigs and sick and disabled machinery.

Now every man who owes a debt ought to pay up. The man who owns 160 acres of land is a king by divine right. He owns down to the center of the earth and up to the stars. With the warranty deed which comes from the United States government and from God there is an implied obligation to make the most of this empire of yours. Every nook and corner of it should be put to its best. The home should be like a splendid picture set in a suitable frame.

THE MISSION OF BEAUTY.

When the whole world is so full of beauty why should it be entirely ignored on the farm? You see 
it everywhere. It sits on the bow which fronts the storm. You see it in those mountains of cloud dressed in gorgeous robes of ruby, and opal, of amethyst and gold, as they escort the retiring day to his chambers in the West. The vast prairies when unvexed by man were gardens of flowers. You plant an orchard and it is clothed with fragrant bloom in springtime, and in autumn it is a bouquet of loveliness with its fruit of red and gold.

God might have made the cherry, the peach, and the apple the color of the stones, but he chose to feed the eye as well as the palate. Through beauty he would - touch the soul. Put a man where you will, and there will be some of the attractions of nature to welcome him. The tropics are filled with flowers, and they alternate in the hemispheres. They salute him in the vast countries of the North. How fascinating the splendors of the aurora as they flash and flame on the walls of the sky! The arch above us is kalsomined with sapphire, and sprinkled with stars. Then the gates of the future open before us on scenes of transcendent loveliness.

Why on earth in these mortal bodies do objects diminish in ratio to distance? Can you look the noonday sun out of countenance as it is? Suppose you could see all things now in their full proportions. You take one glance upward into the empires of glory, where vast cities of stars are blazing and monster worlds lie along the path of vision, and a single glance would paralyze the strongest brain. 
But by and by we will awake in the divine likeness and see as God sees. Then what prospects will open before us as we are greeted with the salutations of the universe. Each star has a mantle in color and fashion all its own,- - no two alike; and the stupendous empire stretching to the shores of chaos will rise as endless fields of loveliness filled with the surprises and astonishments of beauty.

Language labors and falters in the attempt to describe our home in the future, with jasper walls, and opal sea, with gates of pearl and golden pavements and foundations set with precious gems.

When we have such an inheritance of beauty in this world and the next, why should the farmer, who is part owner of this earth, ignore it altogether, especially since God has made him a creator who, with a wizard's wand, can call up visions, marvels in form and dazzling in beauty?

He can take an acre of somber earth and gather upon it the colors of the rainbow, the splendors of the sunset, the radiance of the gems, and it will be a land Elysian-promise and prophesy of what lies beyond.

We are just on the borders of what is yet to be revealed to us here. What changes have been produced in a few years. The carnation of today was evolved from a humble flower. The dahlia had a very inferior ancestry. The phlox, with its marvels of brilliancy and attractiveness, reaching out into hundreds of varieties, was a humble flower born on our great prairies. The paeony of today is one of evolution's miracles. And 
just before us are the most delightful possibilities. How keen the zest of those who hunt for diamonds, pearls, rubies and other precious gems. There is a kindred delight for those in search of new and rare floral treasures. When Rosenfield gave us Golden Harvest among the paeonies he gave, not a single gem, but one that will grow to cheer a million homes. When Terry gave us his Excelsior, Clara Barton and Victor paeonies it was as if he scattered gems that would grow and cheer and gladden thousands.

In my own experience I have seen marvels of new creations among the phloxes, and seedlings of my own raising far surpass many of our choice importations; and so with columbines. What delicate rays of beauty are gathered into some of those newer forms. How much awaits us among the paeonies. What surprises for myself and the world must come from thirty-five pounds of choicest seed. We have only touched the great empire of beauty which stretches before us. 


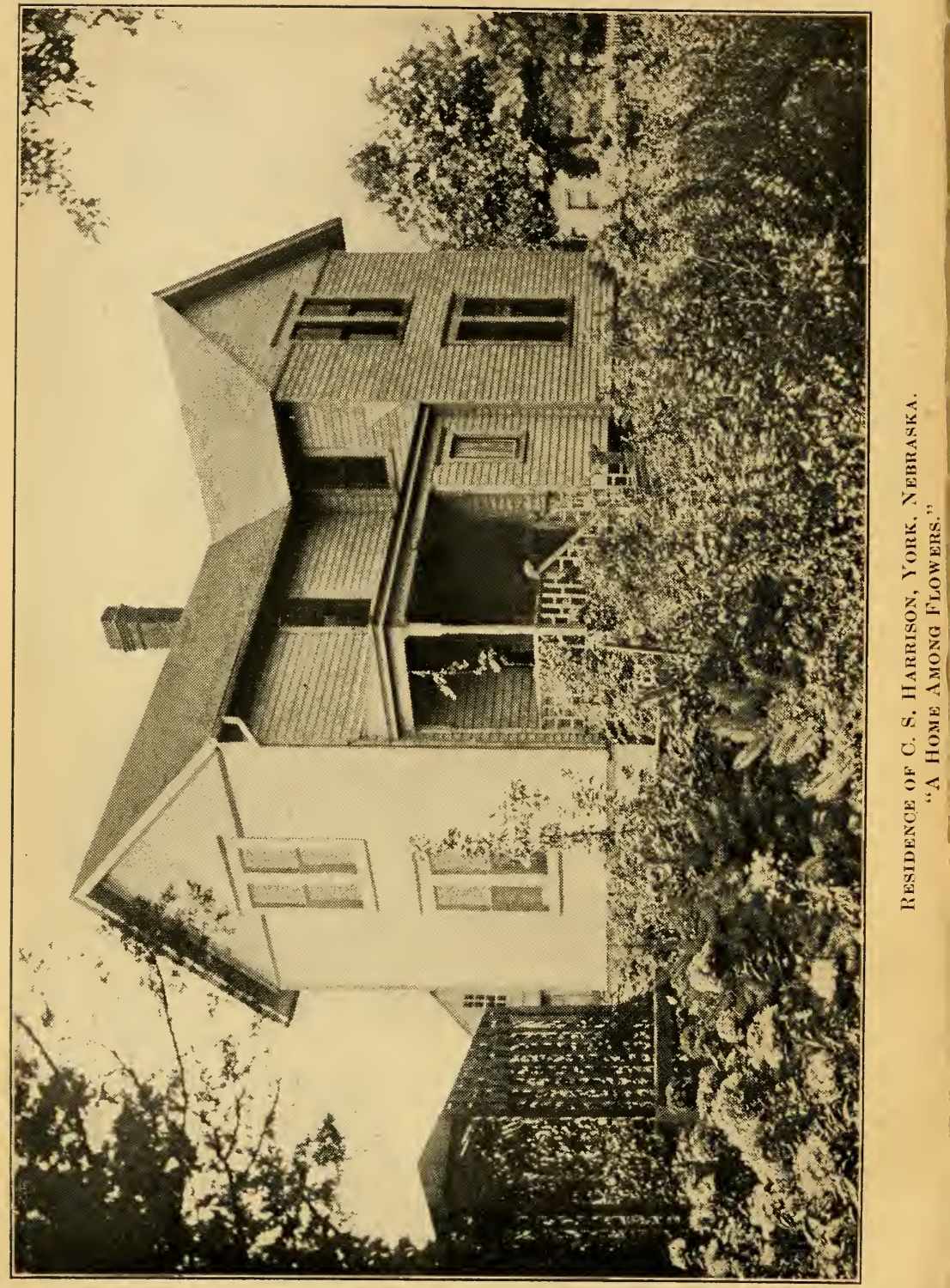




\section{CIIAPTER I.}

\section{THE HOME.}

This should not be a kennel, a sty, a stable, or a barn. It is the dwelling place of immortals. It should be the most sacred spot on earth. The residence need not always be elaborate. There is much of cheer often in the lowly cottage. The spirit of the home is the presence of the wife and mother. If this is lacking the place is a desolation.

The new woman greedily seeks the new vocations, trying by all means to avoid what she terms "domestic drudgery." But there is no occupation more noble than that which ministers to the wants of the loved ones-no hand so beautiful as that from which fall the benedictions of toil and cheerfulness.

People, of necessity, are often restricted in home arrangements.

When our people moved West in ' $4 t$ we lived for years in a house $18 \times 24$ which cost just $\$ 50$. It had a chamber where our sleeping bunks were. We climbed to it on a ladder. There were nine of us. But as means increased home comforts grew. Times have changed. Our farmers are well to do, or even rich, and now can have home comforts and conveniences.

What tremendous influences are all the while going 
out of our American homes. They are sources of power.

From one of them a boy goes to his life work as one of the captains of industry. And mark you, most of the Titans of today, mightier than fabled Thor or Vulcan, came from country homes.

There goes a thoughtful girl with fertile brain and facile pen. She was born and reared in the country where she could get acquainted with herself and learu to think and write and the world loves her.

From another home goes a boy with the soul of a patriot. He enters a naval academy and sooner or later you may hear of another Santiago or Manilla.

Another goes to West Point and becomes a Grant or Sheridan.

We think too little of home. How few expect to live and die on their farms. They hope to sell, and what a shifting race in which the home instinct is almost blotted out!

What spot can be more sacred in its hallowed associations? In that room a little sister with starry eyes and hair of woven sumbeans went into the open arms of a waiting Saviour. Is that room a place for strangers? Should wooden shoes go clamping in places touched by angels' feet?

In that room Grandfather passed away. How the children loved to gather there and listen to stories of the past. What a kindly soul he was and the little ones loved to nestle on his bosom. When he died it 
was the death of the righteous. The gates were opened and heavenly escorts bore him home.

There a mother passed away. I stood by her side and saw and heard it all. Her eyes were closed to earthly things and then there passed by her.on the shores of light the processions of glory. I cannot forget the rapture and the gladness and the outreaching and the last words, "Oh, beautiful, beautiful Jesus!" Should that holy place be desecrated by those who neither know nor care for any of those precious memories?

In that room as a child you lay sick for weeks. At the foot of your bed pictures were changed every day to give your tired soul something new to think of. Your mates came in to cheer you. You have a dim remembrance of the long vigils of father and mother and the good doctors who could not let you die.

What gatherings were in that parlor. Jane and Sarah and Emma were married there. You remember where they stood and how they looked.

There is the dining room where the wedding and Thanksgiving feasts were spread. What happy gatherings of friends and relatives. What delightful memories linger there. Oh, don't sell the home!

In our great West there is hardly a farm but what can be beautified and made homelike. You can build bulwarks of noble trees to shut out the fierce blasts of winter. Evergreens and deciduous trees are waiting to come and defend you.

The choicest shrubs and flowers with continuous 
bloom are ready to spring up at your beck and fill you with cheer and gladness.

On the farm there is too often a lack of conveniencess and comforts. The woman should have a good toilet room as well as her city cousin. The inconveniences to which delicate women are subjected in going to out houses in the piercing cold and through the deep snows might be classed among the martyrdoms. I had seen so much of this that when I built I made up my mind to have a good bath and toilet room first and then build a house around it. I cannot see why there should be such eruel neglect and indifference on the farm. I know a Western ranch where the wife is a noble, motherly woman and she has daughters that are teachers and the husband and father has never even built a small out house for them.

The expense of home comforts is not great. - There is little trouble in having a cesspool at a safe distance, and as far as sanitary conditions are concerned a cesspool is no more dangerous to health than a common vault.

If possible, water should be conveyed into the house. The windmill can do this much better than the wife. The woman has a hard time at best-often without help, and she should have every possible convenience.

\section{THE BOY' ROOM}

Should be large and cheery and well stocked with books and papers. I know a man who has trouble with his boys. Ile owns a half section of land and is 
well off. He built a store to rent in a new town with his surplus money. But the boys had to grope their way to bed on all fours in the garret of a dilapidated sod house. Treat a boy like a dog and he will be one. Give him a good room and have him take care of it and he will be a gentleman instead of a rowdy.

If possible he should have a shop with a good set of tools; not cheap gift affairs, but the best that money can buy.

The best room is none too good for the family. They are as good as the company you receive. The largest and best room is often kept for the guest. This may be occupied a dozen times in a year and the father and mother sleep in a small room. They need the best and largest, and a guest can take up with a smaller one. Better for him to stand it a short time than that the weary ones should use it all the while. Have a good, roomy kitchen with every possible convenience. 


\section{CHAPTER II.}

\section{THE DISCOVERY OF BEAUTIFUL GEMS.}

If in the gold mine in the front yard there should also be found a mine of gems what new zest would be given to research.

Yet it is a fact that we are on the verge of the unknown. Behind a thin veil the good Father has rich treasures in store for us and we can fold the curtains aside and take possession.

A man finds a precious diamond like the Kohinoor or the "Mountain of Light" or "Star of the South" and his fortune is made.

Ancient rulers reveled in the possession of precious stones. When Persia was invaded by the Mahometans they captured a splendid carpet which was one of the marvels of the world. It was 450 feet long and 90 feet wide, and had a border worked in with precious stones to represent a garden of all kinds of lovely flowers. The leaves were formed of emeralds and other green colored stones, while the buds and blossoms were composed of pearls, rubies, sapphires and other gems of immense value. Along with this was a robe of state thickly embroidered with the most beautiful rubies and pearls. That splendid carpet was an imitation of a garden of flowers. True the fabric of 
woren gems would last the longest, yet there was only one of it, while millions of people can have carpets of bloom radiant with a thousand forms emitting their fragrance and displaying their loveliness.

There was the peacock throne. A marvelous collection of jewels-fashioned into the form of that resplendent bird. It was worth thirty millions of dollars. It was a most magnificent bouquet of splendor; yet today the poor man or woman on intimate terms with earth and nature can have collections of forms, tints and colorings which might vie in appearance even with this masterpiece of human skill.

Let some Emperor have his "Great Mogul" or "Orloff Diamond." But a hundred thousand people can have their great, splendid Festiva Maximas and La Tulipes-gems of the floral world. Men have gone mad over the discovery of rich and precious stones. But there are gems of lustrous beauty among flowersgems which do not center all their value in a single object.

I stood by the original Concord grape in that historic town and said: "You grand Old Mother! You know not the trainload after trainload of fruit and plants which have gone forth from your branches, adding millions to the nation's wealth."

Gideon discovered a gem in the Wealthy apple. What a marvel! No jewel uncovered in earth's richest mines can compare with it. Go to any of our Western states and you find this fruit growing by ship loads. 
Somewhere in the unknown are other fruitsluscions, hardy and prolific, which will yet add millions to the nation's wealth.

No one can take out a patent on these discoveries. The wide field is open to all. You can be an independent mine owner, and perhaps some quiet farmer may yet capture the prize for which all the Northwest is longing.

In floriculture what marvelous changes have been made in roses. The single rose is the product of $\mathrm{Na}$ ture. The double rose is the product of Nature and art. What marvelous crosses are being made. One day in the East I rode on the cars with the noted Jackson Dawson, of the Arnold Arboretum, and he was taking eight hybrids of the Wichuriana of Japan. There is no limit here, and a wide awake boy or girl can carry on the process.

What improvements in lilacs, spiræas, and syringas, or Philadelphus. This same Dawson showed me a syringa of marvelous beauty and enormous flowersone of his own creations.

Some one crossed the delicate little Thunbergi Spiræa with the Multiflora and that gave us the Arguta, which blooms with the tulips-a snowdrift of white-the earliest of all. And it has such persistent foliage that in the autumn it is like a flower garden of itself with its rich tints and marvelous colorings; thus making an attractive display at each end of the season.

Lilacs are all the while being produced from seed. Plant the choicest kinds with the rich diversity of 
bloom and foliage and from the seed you will have some surprises of loveliness.

How much has been achieved by the wizards of horticulture who have opened new gates to let us look on broad empires of possibilities. And how much is being done all the while along the lines of private research.

Take the carnation. Only a few years ago it was a humble flower and now a glory fit for the dwellings of kings. And the limit of its possibilities has not yet been reached.

When Rosenfield gave the world his Floral Treasure, and Golden Harvest, he discovered gems whose beauty, soon to be increased to millions, will make glad the homes of the great Northwest and cheer up the prairie desolations.

Father Terry, of Iowa, has given us over one hundred paeonies. Among them the Victor, which is victorious, and Excelsior which excels, and Morning Star with delicate rays radiating from a heart of gold. What a troup of loveliness to rise up and bless the old man as he journeys to the land of the setting sun.

And see what great work he has accomplished in bringing cheer to so many homes. It is said he is a benefactor who makes two blades of grass grow in the place of one. What shall we say of the man who in the place of none shall clothe the brown earth with a carpet of beauty on which the soul can feast-who discovers gems that will increase to millions? There is 
altruism here. It is like an almoner handing out the richest gifts of Providence to a needy world.

What I want to do is to awaken a zeal in your hearts, so that you can go out and possess these new fields. There is a charm in taking the flowers already established and propagating them, thus clothing barrenness with beauty. But we have reached that point where the ordinary man or woman, boy or girl, can add to the treasures of the world and the delights of society.

A quiet woman in Indiana a few years ago planted some paeony seeds. One plant she named, on my advice, General Lawton. It had a splendid large flower. She sold it for $\$ 100$. Another, named for her departed husband, brought $\$ 150$. Another of her creations-Walter Morgan- has a delicate flower of lovely fragrance, and of pure gold. There is no law which forbids research along these lines. No warranty deed on God's fields with signs up, "No trespassing here."

What wonder, when I see these things, that the fascination comes over me and I am planting many pounds of seeds of choicest paeonies and am willing to forego the delights of heaven a few years to see the new forms of loveliness they will unfold.

\section{NOTE THIS FACT.}

When flowers are first developed from the original type, they easily revert back again. It probably took a thousand tests to produce a double dahlia. Now the family is so well established that the progeny retain 
the characteristics of the parents. A lady not long ago saved some dahlia seeds and was amazed to find an immense, symmetrical double white, which she named Surprise.

Last spring I sowed a lot of seeds of choice cannas, and was delighted to fine some of rare merit-fully equal to many of the finest named ones.

I keep about fifty kinds of mixed columbines; and their product gives an almost endless permutation of form and color, and I note many far superior to the old named varieties. There is this about the columbine family,- they use all the prismatic rays in making their garments of loveliness.

Take the phloxes developed from our wild prairie flowers. They have pushed ahead and branched out into so many varieties their mother would not know them.

This summer I have raised from seed of the best some twenty new sorts-surpassing most of our imported ones.

Now remember! these gems are not like the precious jewels which never multiply. You can increase them rapidly and you can have a garden of delight all your own; and standing there like a god among your new creations, you can explain the petition, "Let the beauty of the Lord, our God, be upon us."

It is delightful to stand as an interpreter to unfold the divine plans and uncover His munificence to an admiring world-to introduce God to men. 


\section{CHAPTER III.}

\section{THE PREPARATION OF THE GROUND AND THE PREPARATION OF THE OWNER.}

People often have crude ideas about planting. A lady bought some roses and went out with a case knife and cut a small hole in the sod, stuck in the bushes not as deep by two inches as when in the nursery, and then said: "Thank goodness that job is done." Of course they died, and she blamed the rascally nurseryman for sending out stock that would not live.

There is little use of planting till the ground is ready. It should be in a well pulverized and friable condition so that trees and plants can readily draw food from it. If you leave a piece in grass, or break up the native sod, the soil becomes granulated and does not pack closely around the roots, and so cannot feed the plant. The best way would be to manure well and summer fallow. Then you have the soil in the best and most responsive condition.

You may want to plant near where you have large trees which you wish to save. Now here is a problem. How can you make trees and plants grow in a domain already pre-empted by great, ravenous trees which often send out roots twice as far as they measure in length?

You may talk about trusts and monopolies; there is 
no trust like a great, strong cottonwood, and you might as well cut it down. It wants the earth and will have all it can reach of it. If in town it will take your own and your neighbor's garden.

Other trees you may wish to save, but they are not so ravenous, and you can readily check their aggressions. Suppose you have a row of elms or ash you wish to keep and yet you want to plant near them. Dig a trench three feet deep about six or eight feet from the trees. You will thus cut off all the feeding roots that are sapping the ground you wish to plant.

Now prepare your ground thoroughly and do your planting. Of course you fill up the ditch.

"Will not the roots cross the trench again?" Certainly; but it will take time, and thus give your new trees and shrubs a chance to get started. Then if trees are checked in one direction they have a tendency to work harder in another direction, and by the time they invade their old territory your planting will be so well rooted and established that little harm can be done.

People who plant near large trees say it is the shade. that does the mischief. But in our Western land of hot sumshine, what little shade there is would be helpful to the young trees. The trouble always is with the roots.

When you have your ground all ready you will find it just hungry for the trees and plants, and will give them a cordial home.

While the ground is being prepared you had better prepare yourself. 
I never could understand why the farmer considers borticulture a sealed book which he never can open. It is a part of his business, as much as raising wheat, corn, cattle and hogs. It is easy, too, and intensely attractive. Strange that a man will go by a tree or plant and know nothing about it, and be a perfect stranger to his kindest neighbors. He shuts himself out of a wide world of enjoyment.

The more one studies the more he is impressed with the

INTELLIGENCE OF THE PLANT AND TREE WORLD.

We should regard the tree as an intelligent, hard working, honest friend, endowed with an intuition that is amazing. We talk of the "cunning of the rat," and I sometimes think a tree is endowed with the same keenness.

I know a cottonwood the roots of which plowed their way through hard and compact ground two hundred feet to a cistern and drank it dry. The people wondered what had become of the water, and there stood the tree smiling in triumph, its leaves green and fresh, and it was growing with the greatest vigor in a dry time.

I have a cottage in the Rockies where I love to be with nature and watch things. One fall, on a very dry mountain side I saw a lot of ponderosa pines which seemed to be dying. I examined them closely. The soil was poor, or rather no soil at all, only decomposed granite, and it had been very dry for two years. Those 
trees seemed to have studied the matter and decided they could not take the whole family through and so they dropped over one-half of those long needles and har strength enough to support the rest. In my yard was this same variety of pine, but the grove was fresh and rigorous and they were holding all their needles. I wondered how it was. About 150 feet from them was an irrigating ditch. I having occasion to dig near the banks, I found a whole train of the roots drinking up the water and sending it back to those trees.

Often I have noticed fresh and vigorous looking trees on the brow of rocky hills where there was no soil and the wonder was how they could thrive so well. Going down the hillside perhaps one to two hundred feet, I saw where the soil had washed away; there the roots were running down to the stream and pumping the water up the hill to the trees.

A neighbor had oceasion to move some large cedars. He did it well, exercising the greatest care. In a few weeks he called me in and said his trees were dying. I examined them. "No, they are not, only they know more than you do. With their root system partly destroyed they know they cannot carry the foliage in full, and so they are 'cutting the coat according to the cloth,' and doing it, too, with the greatest nicety. You will notice they are only dropping the foliage from the tips and the branches just where you should have eut them off to have the top proportionate with the root. They are doing this, too, with mathematical precision." The event proved the trees were right. They under- 
stood their business and all lived. The dead limbs were cut off and the cedars made a fine growth and are really beantiful trees.

Trees will not only go after water but they will go after food. I once lived on a place which had a very rich piece of ground for a garden, which a former resident had discarded. He said he could not make anything grow there on account of the shade. Digging down in the rich soil I found it so full of tiny rootlets that it seemed like a piece of sponge. I dug a trench as described, cutting off the roots, and had the finest garden in town. When I left they invaded the ground again and it was given up.

Some years ago I addressed the Horticultural Society of Worcester, Mass., on this topic, "Intelligence in Trees."

At the close of the meeting that venerable prince of horticulturists, O. B. Madwin, the president, said: "I am glad you spoke on that topic. I had a row of apple trees that of course were throwing out their roots as foragers in every direction to gather food for the trees. One side of the row I dug a trench and put in a lot of manure and made it very rich for pieplant. Two or three years after I had occasion to dig up those trees and $I$. was astonished at the keenness of intelligence displayed. I found the roots had all turned and made for that rich food, some had gone past the trees, some had gone under, and all with a keen scent aimed for that trencl.."

Did you ever stop to think of the splendid civil en- 
gineering of a great tree out in the open with its wido spreading branches covered with dense foliage?

Present this problem to an expert: "Here is a tree 75 feet tall with branches having a spread of 50 feet with an immense, well-rounded head. We want you to brace this so that it will stand in a wind blowing 80 miles an hour and not fall over, and you must do it at the base." It would take an immense amount of figuring and an astonishing amount of bracing. But that tree, never having studied mathematics or engineering, goes quietly at work and solves the problem and does it well. Such a tree left entirely to itself seldom blows over. It sends down an immense tap root, and then out go the laterals like tent cords, and as the tree grows, the cords all grow stronger till they get to be immense cables. Look at the base. How gnarled and toughened and what a gathering of power there, as those mighty arms of wood go out to clutch the solid earth, and hold the tree in place. Years go by, the top becomes heavier and the weight of the wind on that immense leverage is something tremendous, but the tree seems to have figured it all out and is prepared by additional and stronger braces for every emergency.

Before me as I write this there stand a cherry tree and a Japan tree lilac. Both are good friends of mine and we think a good deal of each other. The lilac is destined to be a large tree 6 inches through and :50 or 40 feet high. I take the best of care of my trees and meet their wants as I would take care of a horse or 
cow. What is the result? The lilac was one great bouquet of fragrant loveliness. We give you a very imperfect picture of it.* And that cherry tree tries to outvie itself both in a mantle of splendid bloom and again in an immense crop of luscious fruit. The tree. is a massive flower of crimson and green as it is loaded with its burden.

The poet prophet speaks of "the labor of the olive." That is a fine gem of poetry and opens before us a marvelous chapter on our relation to our trees. In winter they are quietly sleeping-resting to get ready for a hard summer's work.

Spring comes and they begin their labor. If we. could look through the soil we would see busy toilers there by the myriads. Tiny rootlets go out in every direction as foragers bringing in supplies. The flowers are hard at work throwing out those thread-like roots all eager to gather in something. They work like noiseless hives of bees, and as busy bringing in their supplies. Silently the trees, shrubs and plants partake of the nourishment. They work like a prayer in secret which is rewarded openly. Look at these mantles of ermine and gold that cover the bushes.

See the emerald crowns upon these trees growing fresher and greener. Note the immense amount of quiet work in the growing branches and in that thick new circle which is embracing the trees.

Look at these flower's on dress parade before you and all around you day and night in the front yard and in

*See page 63 . 
the rear; among the ornamental and the fruit trees, that intelligent host is at work for you yielding tribute as much as the horse does his strength or the cow her milk. How much a man loses who does not have these intelligent servants at work for him.

All around $n \mathrm{~s}$ in air and earth, in shower and sunbeam, are the unseen treasures-thousands of bushels of luscious fruits held in solution waiting for you to give mediums for their crystallization so they can materialize for you. Oh, the beauty of it and the pathos of this noble army waiting to come as faithful toilers to work for you, or to stand as faithful sentinels to guard your home. And did you ever think that all the rays of light in the air about you, all the gorgeous colorings woven into the rainbow, are just waiting to fashion themselves in forms of radiant loveliness in the tulip and columbine, the phlox and the paeony, and that lovely army God created to cheer our homes?

Just give the good Father a chance to see what $\mathrm{He}$ can do for your.

But remember this, that the most stupid of these silent servants knows enough to die if you don't take good care of it. 


\section{CHAPTER IV.}

DON'T BE STINGY.

One great drawback in adorning the home grounds is penuriousness.

It is strange, when people are fixing up the house, they will spare no expense in the building or furnishing; but the moment they go outside, the purse strings are pulled tight, and anything costing more than 25 cents is considered an extortion.

For instance, a good strong rosebush, well rooted and ready for business, is generally sold for 50 cents. But the economical lady says: "That is outrageous. I can do much better than that. I have a catalogue and price list of a firm that will sell 12 choice kinds for $\$ 1.00$; and they will come by mail, too, so I will save the express." She sends for them and gets 12 tiny little things that need a microscope sent along with them. She plants them out, giving ordinary or even careful attention. If she saves one out of the number she will do well; and that will probably be a poor, sickly thing, and it will take about three years to bring it up to proper size. So she has paid out her $\$ 1$, and lost three years. This mail order system is a great drawback. It is all right in its place, if you want house plants, or small ones for the nursery, where they can have special 
care. A man wants an evergreen. If he gets a goodsized one it will cost him something. But he hears where he can get 100 seedling evergreens sent by mail for $\$ 2.00$. He orders them, smiling in the meantime at the way he has circumvented his nurseryman. He plants them. But they are too small to go out in the open, the reflection of the hot sun from the ground kills them, or the dry weather, or the weeds take them. Perhaps 4 or 5 will live, and they are little sickly things, and the money is gone, and the time lost, and nothing to show.

So for immediate use for outdoor planting the mail order system is a delusion and a snare. But it is very hard for people to see the difference between a chicken that has just learned to peep and the fine fat fowl all ready for market.

Another serious drawback is the tree fakir. He was built without a conscience. He never comes to the same place twice. It isn't safe. He sells an immense amount of lip and cheek and very poor stock. I met one not long ago, who told me how he worked it. Said he: "I sell 7,000 roses a year at $\$ 1.50$ each. I just razzle dazzle them with big names and down they go. I sell lots of picea pungens-Colorado blue spruce. I always get $\$ 2$ apiece for them, and then substitute Black Hills spruce, which I can buy for 20 cents. They don't know the difference."

The tree fakir is a hynotist. He gets his customer in a corner and he is at his mercy.

My neighbor thought she would try a new man, and 
he came along with abundant professions of double distilled honesty. That is, he said he was honest, and he ran down those mean fellows who would betray the confidence of their customers. For instance, he allowed no man to plant his stock but himself. He wouldn't trust them. He would plant them so as to be sure they would grow. He had something brand new, which for size, fragrance and blooming capacity put every known variety in the shade.

He would sell his roses for the very low price of $\$ 2.00$ each. She said she would take three. He planted them that day, and she paid him $\$ 6.00$. They were nothing but wild rose bushes, and dead at that.

Such men discourage people. But they are a race by themselves. I have known them to sell very choice kinds of apple trees for 75 cents each, and then go to a nurseryman's brush pile and pick out refuse trees and tag them and palm them off at such high figures. So beware of the tree fakir.

On the other hand, there is no class of men who are doing more for the material benefit of the country than our hard working, enterprising nurserymen and their agents. They are straightforward and honest. They have to be. It gives them the heartache sometimes to see their experience and integrity all set aside for the fakir. With too many all that is needed to secure an unlimited confidence in the dealer is that he is a perfect stranger. Then he is trusted implicitly.

Your nearby nurseryman has his reputation at stake. He has a sort of fatherly interest in every tree and 
plant that goes out. He wants them to live, and he rejoices in your success.

Again, his advice is worth much. He can tell you what will succeed and what will not. Every nurseryman who does an extensive business has spent hundreds, if not thousands, of dollars in finding out what he could not do; and he would give you the benefit of his experience. If you don't take his advice, you will meet some fakir, or you will get some fine eastern catalogue, giving a description of things that do well there, and you will be tempted to buy. Perhaps you are attracted by the charming pictures of the kalmias, azaleas and rhododendrons. You just buy the pictures if you wish, but let the plants alone; for you can no more raise them in most parts of the west than you can raise peaches on the north pole.

We will endeavor to give you a list of stock that will succeed in your section, and if you are in doubt consult the nearest responsible nurseryman or the superintendent of your state experiment station.

But let us return to this penuriousness which strikes a person as soon as he steps out of doors. He has built a good house. Why don't he and his wife go to the second hand store and hunt up the cheapest bargains and buy some old rag carpets, and rickety chairs, and cheap tables with broken wings, and bedsteads with those telltale specks on them, just because they are cheap? O no. They must have nice carpets, good furniture, and everything to match. A $\$ 50 \mathrm{rug}$ is just the thing for the 
sitting room and a $\$ 25$ mirror is the thing and the chamber suits must all be first class.

Now the outdoor furnishing will cost something. A beautiful silver spruce is $\$ 2.00$, a silver cedar about the same, choice tree lilacs are scarce and cannot be bought for a song, choice syringas and spiræs will be worth 25 to 50 cents apiece. Tulips will be $\$ 2$ or $\$ 3$ per 100 . You should have as many as that. You can get lots of paconies for $\$ 10$ per 100 , but you had better pay $\$ 1$ each for a few choice ones. Remember you cannot get something for nothing. Do keep away from the bargain counter. There is nothing so expensive as cheap, poorly handled nursery stock. You should begin right. You go into that new house and home, and the moment you enter it it begins to depreciate in value. Use your carpets and furniture a year and they become second hand goods. But it is not so with your front yard. Every tree, shrub and flower you plant is at work developing your gold niine. You lay out $\$ 50$ and it soon grows to $\$ 100$. If you want to raise poultry to sell, it is cheaper to pay $\$ 2$ per dozen for a choice strain of Plymouth Rocks or Brown Leghorns than to pay 25 cents a dozen for eggs from common fowls. You can get all the old fashioned lilacs you want for 5 cents apiece, but you cannot get the best kinds for that. You can get a common soft maple for 25 cents, and it will grow to be a tree. You will have to pay $\$ 2$ for a Schwedlerii purple leafed maple whose crown in springtime will seem like a brilliant, mammoth paeony outlined against the sky, but the latter will pay the best in the long rum. 
Your home should be like a beautiful picture, and your grounds should be like a fitting home for it.

Don't be satisfied with putting a thousand dollar picture in a ten cent frame. 


\section{CHAPTER V.}

\section{LAYING OUT THE GROUNDS.}

Much depends on a plan. Some plant in a haphazard way and if they find a space stick in a tree and there is no system whatever.

You need a plan for the front yard as well as when you built your house. We can give no definite rules or formulate any definite plans; for in farm adornment you do not want to run everything through the same set of molds. You want diversity and to have no two grounds exactly alike.

This subject of laying out grounds is a broad one and would make a book of itself. In fact a good many books have already been published on this theme.

S. Parsons, formerly superintendent of Central Park, New York, has lately written a work, which will give you some valuable hints. But it is better adapted to the east than to the monotonous west. Remember, however, that many things recommended, though they do well in the east, are worthless in the west. The Department of Agriculture has lately published Bulletin No. 185, "Beautifying the Home Grounds." Send for 
this. It is free, and though not very full, it gives many useful hints.

I will, however, make some suggestions which I hope will be helpful. I like what I term the amphitheater plan. This is nature's plan. Often on the edge of a native forest you will see little parks surrounded by trees. In the background tall trees. Then as they are more scattering they branch out more, and do not grow so tall, and then as if to hide the trunks and decaying limbs there will be prickly ash, high bush cranberries and hazel brush. You notice these grow taller next to the trees, the shade compelling them to climb toward the light, and then as they come down to the border they spread out more. This native park gives a good suggestion for the home grounds, which of course will be a little more formal.

Suppose you have one or two acres you wish to fix up. To the right and left on the sides of your plat you plant a row of elms. These are rank, strong growers, and you can depend on them. Next plant a row of basswood or native ash, which do not grow as fast. Perhaps next you will want a row of white spruce, so hardy over Minnesota and the Dakotas. Now you are coming down. You can back up against your trees circles, or semicircles of shrubbery. If a circle, put in a spiræa opulifolia in the center, for this is the rankest of all. Then Van Honti, dropping in now and then a golden one. Then the Arguta. Then you come down to the Collosa and Collosa Alba. Then the Thunbergi, and lastly the Anthony 
Waterer. You have here a mound of beauty with a diversity of foliage and a succession of bloom.

For syringas, put the strong grandiflora in the center. Then coronarius. Then Gordons; next the old sweet-scented of our mothers. Then put in the dwarf Lemoine and Avalanche with their profusion of bloom. Here, too, you have a wide diversity both in leaves and flowers and a wide range of blooming season.

For lilacs, put a tree lilac in the center, either the Chinese or the Japanese, then the Villosa of half tree form, then the Bretschneider and the Josikaea, then the Emodi and Oblata, then Senator Volland, Charles $\mathrm{X}$ and others, and you will have one of the most charming collections. Some of the leaves will be almost as large as your hand, and then there will bo the exquisitely delicate ones of the pekinensis and the cut leafed Persian, while the time of blooming will range from early spring till near the first of July.

Now your amphitheater is coming down toward the arena. Bring on the perennials and back them up against the shrubbery. There are the tall and showy tiger lilies, then the rank growing delphiniums or larkspurs, with their immense spikes of bloom-hardy up in Manitoba. You should not have formal or continuous rows all the way. Make breaks here and there. Now put in the radiant phloxes. Then the oriental poppies, with their flamelike splendor. Then Gaillardias. Somewhere in the background you will want cannas. They vary. Pillar of Fire grows 7 feet tall, holding up a bloom like a torch of flame. These go in the backgrourid 
and those more dwarfish in habit are placed at the front. You have now come down to your walk. You can have a patch of grass if you wish. You will probably have two walks. Between them you can have grass or flowers. Near the road will be the grassy lawn. Let this be open unless you put in a Colorado Blue Spruce or a White Spruce from your northern forests. If you have trees on the roadway keep them trimmed up so the view will not be obstructed.

I should have a large bed of tulips near the house to give their early spring cheer and the promise of summer unfolding glory. These bloom and wither, but you can plant alternate rows of phloxes, which the last of June will commence their work. By this arrangement you can stand in your porch and receive the smiles and the salutations of this field of loveliness and in the afternoon your tired wife can visit with the best dressed and most fashionable and aristocratic company on earth-those that never gossip, that do their utmost to please her, that fairly worship her as a goddess with their sweet incense. This plan unfolds the whole scene at a glance and enables the passerby to see it also. A man does not make all this outlay for himself alone. It is for his friends and neighbors and that lovely scene will silently preach the evangel of beauty to all that pass by. One beautiful yard in a neighborhood would be an inspiration to a whole community. The time will come when the tired farmer will take a half day off and spend it profitably in the grounds of his progressive neighbor. Flowers need not be confined to the front; there can 
be some between the vegetable garden and the house - companions of the wife as she does her work.

There is another system which is the opposite of the open one. Your grounds are hidden by a hedge and you have winding walks; and as you turn you have altogether new views and are in a sort of a labyrinth of beauty. The house is hidden so that when you come upon it it seems like a new discovery. The old English system was one of seclusion. A high wall with coping of ragged stone or glass from broken bottles, making it hard to climb, enclosed the grounds. Thus secluded from public gaze the owner had everything to himself and his special friends. But this is rather a selfish plan.

If you go to the Shaw Gardens at St. Louis, you will find that the founder brought this system from England and enclosed a portion of the grounds with high walls and iron gates.

If you can afford it, it would be well to consult a landscape gardener like Mr. Nutter of Minneapolis, who makes this matter a life study. If you cannot, get what aids you can and in the long winter evenings take your rule and paper and make a plat, planning for every tree and shrub and the distance apart, so when spring comes you will know where everything belongs. You will find this a delightful study, forecasting the future and living on anticipation of a fair elysium which is to front your home. 


\section{CAUTION.}

In all your plans do not forget that these choice things must have constant care and good cultivation. It is a sad sight to see grounds well planted left to weeds, which like robbers delight in stealing the food which belongs to the flowers.

Plant early in the spring. Do not wait for the trees to leave out first. Serious losses result from late planting. The tree wants time to get ready for its summer work and start the roots before the leaves appear. See that the soil is pressed firmly around the roots. Plant a little deeper than they were in the nursery. Always plant in a slight depression, never on a mound or ridge. Remember "eternal vigilance" is the price of beauty as well as liberty. But working among these lovely things and caring for them is one of the most delightful occupations on earth. 


\section{CHAP'TER VI.}

\section{HINTS AND SUGGESTIONS-SELECTING TREES AND SHRUBS.}

You should choose for hardiness those that grow naturally in your own neighborhood, and those that have been well tested and are recommended by your nurseryman.

For instance, I found in Manitoba that cottonwood did. well, and yet care must be taken to secure northern trees. Those that came from Iowa or Nebraska would not answer at all.

Eastern butternuts are worthless in Nebraska, and yet they grow wild a hundred miles north of St. Paul, and probably those would be all right anywhere in the west.

Some one says "plant red cedar." That depends on where you get them. Those growing in your own neighborhood are all right. Those grown in southern Illinois are tender in Nebraska, and the famous Platte cedar will not do in North Dakota.

That is one trouble with fruits. Apples that do well in Illinois and Iowa are worthless in Minnesota, and at infinite expense and patience a new race has been created. It has taken a generation to move apples three hundred miles north. Years ago I sent seed of the pon- 
derosa pine and concolor fir to Prof. Green. He raised beautiful trees from them. But the winter of 1904 was famous for its death waves which sought out the weak spots of everything. It hit Nebraska and damaged many things supposed to be ironclad, and then it hit Prof. Green's plantation hard, and many pines went under' and others had a ragged look and many of the beautiful concolor firs were killed outright.

What was the trouble? The seeds were gathered from the foothills of the Rockies. Had it been taken from the high altitudes where for ages the trees had been inured to deep snows and intense cold they would have been all right. The picea pungens and Engleman spruce are taken from an elevation of 10,000 feet, and they are hardy in Manitoba.

White spruce from Maine and Northern Michigan are worthless in Nebraska.

But a portion of that great family have worked their way down in the Black Hills about 300 miles north in a dryer climate. They are the identical white spruce, but as their habitat borders on the great plains they are all right. White spruce from the northern part of Minnesota can probably be moved down to any part of the state. We can move the conifer of the Rocky Mountain foothills down to almost any portion of $\mathrm{Ne}$ braska and have it do well. But you cannot always move it north with safety. A state will have many distinct districts. For instance, white pine and Norway spruce will do in our river counties, when west of the 100th meridian they are worse than worthless. The 
Scotch pine is a good tree for the north, but it cannot live where the hot winds sweep the great plains. On the other hand the Austrian pine for adaptability leads all the conifers in most of the states west of the Missouri river. I have seen splendid specimens in Oklahoma, and on the dry Kansas and Nebraska plains. Norway spruce and white pines do well in Eastern Minnesota, while in the western part of the state and in the Dakotas they would be very uncertain. Again there are some foreign trees that surprise us by their adaptation to most of our conditions. The European mountain ash is a success if you can keep the body from sunscald. European white birch in most of the west does better than the American type. The Russian olive is one of the hardiest trees for the semi-arid west and northwest. For 15 years under the 100th meridian in Nebraska it took the lead for size and vigor of all the native trees. After that it gave attention to producing seed in immense quantities, which dwarfed it and allowed other trees to get ahead of it. For a time it headed the list as the best forest tree for the plains. The Norway maples seem hardy in our Northwestern states. There are often freaks also among our ornamental shrubs.

While in Manitoba I was surprised to see the spiræa opulifolia, which I supposed the tenderest of the whole family, doing well. We are a little fearful of things that come from China and Japan, yet at Brandon there was the villosa lilac, which I thought would prove the most tender of all. The Japanese tree lilac is a great success on the Minnesota experiment grounds and Prof. 


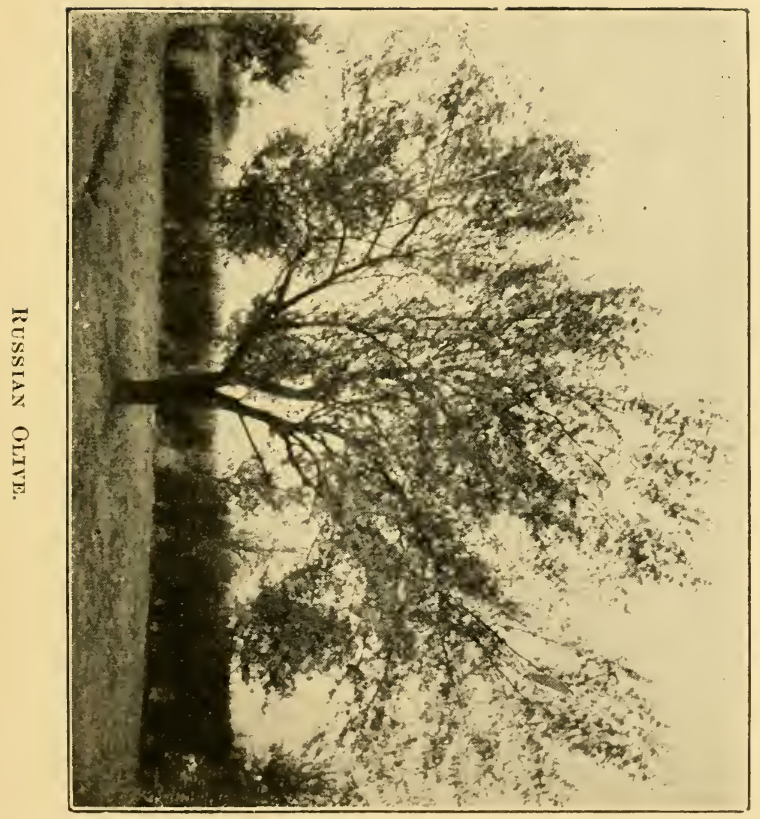



Green has raised them by the hundreds from seeds grown there.

As a general thing the deutzias are worthless in the west and the syringa or Philadelphus is shy about crossing the Manitoba line. They seem to be doing all right on the experiment grounds of the agricultural college of Minnesota.

So you see the need of consulting your nurseryman, who has given years to patient research and experiments. Don't trade off his experience for the alluring pictures and smooth tongue of the tree fakir. It is of prime importance to plant things that will live. It is sad to think of the millions expended on failures. While out lecturing for our university in a distant city, in an address I noted that many things, especially azaleas, could not be made to live in Nebraska. A gentleman took me to task. "You just walk three blocks and I will show you one of the finest azaleas you ever set eyes on." Said I: "I wonld walk ten miles to see a good thrifty azalea growing in this vicinity for I lost 500 of as fine plants as $I$ ever saw and they were under a screen at that. You cannot make them live in our soil." "Well, I'll show you and I have ordered 12 azaleas. I am to par $\$ 12$ for them." He triumphantly showed me a fine bush which he and the owner said was one brilliant mass of bloom. "But where is your azalea?" I asked. "That bush is a wigelia." The man was crestfallen. "Well," said he, "I am in for it. But I'll let my order" stand." I told him he might as well plant oranges.

There are some things we cannot account for in 
shrubs. We can only determine their adaptability by actual test. For instance Prof. Green says that in the genial climate of the Kew Gardens of England the hydrangea grandiflora is not considered hardy, while it grows to a tree in Minneapolis and laughs at 40 below. I also saw it in Manitoba.

\section{RAISING PLANTS FROM SEEDS.}

In the west and northwest we often have strong drying winds just at the time when we want to plant seeds. Many of our perennials and annuals have very small seeds. Even nurserymen do not attempt to raise columbines, oriental poppies, gaillardias and phloxes from seed, but get the plants from the east. Unless one is short of means and has a little extra time he would better not bother with seeds but get well established plants.

You must observe this rule about planting seeds: the smaller they are the shallower. If you want to raise celery (some of you have tried it) you have found it could have only a slight covering, while if you plant a black walnut it should go four or five inches deep.

Another thing: the ground must never dry while seed is germinating. This is fatal. There may be moisture enough to start them, then there comes a drying wind, and that is the end of it. Often complaint is made about the seeds when the trouble is with the grower and the weather. Some extremely small seeds are best started in the house. Plant very shallow in a pan. Often we just dust a little earth over them and then put on sifted moss, which will retain the moisture. A piece of 
gunnysacking or soft cloth that will keep moist will answer; and this is kept damp all the while, and is removed as soon as the tiny plants appear.

I have been troubled immensely in trying to grow seeds out of doors in the uncertain climate of the west, till with long and patient experiments I solved the problem. Take boards about a foot wide and build a pen $4 \times 16$; or make your bed according to the number of plants you want to raise. I often have 20 of that size. Nail laths together on crosspieces to shut out half the sun. It takes about 16 laths for a square. Your crosspieces are nailed on about two inches from the ends of the laths. Push the alternate laths over a little so you will gain a little more than four feet in the length of your square. You will find this an advantage, for they will catch on the boards more readily and will not be so easily blown off. You must brace the square so it will not get out of shape. Now prepare the soil in your pen thoroughly. You can do it best before your pen is made. Have the ground perfectly level. Sow the seed and cover according to the size of the seed. See that the earth is moist, and in good condition before you sow. Having covered the seed put gunnysacking over them and give them a good soaking every night. Your screens are made so you can put them on and off readily. You must take them off to water of course. Keep them on all the time. When your seeds begin to come up (and they cannot help coming up with this process) take of the gunnysacking and water as the plants need it. If you are raising oriental poppies keep the screen on 
all summer. I lost 50,000 one year by taking off the screen. It is different with gaillardias and columbines. When they are well rooted take off the screens. They do better in the full sunlight.

How $\$ 10$ can be made to grow to $\$ 1,000$. If I were on a farm I know that in a few years I could accomplish it, and it is largely by the processes I am describing that I have succeeded in producing one of the largest ornamental nurseries in the west in a short space of time. If you only knew it, there is a whole bank of money in your brain and hands: Six years ago I found myself disabled, so I had to leave in a measure a professional life which I had carried on for more than forty years. My health was poor and nerves worn threadbare by a strenuous life. I found myself without money and the wolf of want was looking in at the door. Too many under the circumstances would have been appalled. But all along I had taken delight in horticulture and for years kept a state experiment station. An important position in the east placed me in contact with the Massachusetts Horticultural Society, of which I became a member, where I formed the acquaintance with some of the foremost men in the nursery business. Of course I got all I could out of them. I had a splendid opportunity to see the parks and private grounds of New England, and get acquainted with the superintendents and gardeners. I gathered and stored all the items I came across, and when I must give up my life work I had shattered health, no money to speak ofjust head and hands, "heart within and God overhead," 
and good, kind old Mother Nature ready to take me by the hand. I went to work and pulled a nursery out of my head and hands which visitors tell me is the best in its line west of Chicago, and I think they are correct.

Here are thousands of lilacs in 50 different kinds, 20 kinds of syringas and as many of spiræas, a fine lot of viburnums, $\$ 5,000$ worth of paeonies in 400 varieties and perhaps 200,000 choice perennials. When I talk of gold mines I am no parlor knight. I have done most of the work myself at an age when most men retire. I do not mention this in a spirit of egotism, but simply to show what an old man thrown aside can do; and a young man certainly has greater advantages.

If we could call our powers into play we could dress up this dirty old world of ours so the angels would hardly know it.

How it was done.

I planted a lot of evergreen seed, using the screen system. Then a lot of perennials, and they grew. I secured a few lilacs of leading sorts and grafted them, a bit of scion on a piece of lilac root just as the nurseryman makes his apple grafts. I found that most kinds of spireas, notably Van Honti and opulifolia, would grow from cuttings like willows, and so with the Philadelphus or syringas. One plant in a short time would make 100, and then 1,000. I planted late in the fall and mulched, or else early in the spring. I secured a lot of choice trees when they were small and then planted them on rich land, and looked on to see them grow. Choice paeonies, some costing $\$ 2$ to 
$\$ 5$, I found, if well cultivated in rich ground, multiplied fast. And now, my dear reader, if I can only "stir up the gift that is in you" and have your hand know its cunning and your brain its power and resources, I shall feel that I have done a good work. We taik of waste and there is too much of it. For two years the farmers of Nebraska lost wheat enough to easily feed the whole state, by just waiting for a threshing machine so they could thresh out of the shock. But the greatest waste is in our unused and undeveloped powers and uneducated hands.

\section{DOGS AND FLOWERS.}

I sometimes think our boasted civilization lies along the borders of barbarism, - a worthless dog preferred to a winsome child.

"Nus," said a little fellow who was taking an airing in his little carriage, "who vas dat lady wid a little dog dat tissed me?"

"Why, that was your mamma."

There are thousands of childless people who center their affections on a contemptible cur.

A friend of mine was taking a ride on the cars. Near Kansas City a girl got in bringing a little pug in her arms. She coddled him and petted him and then said: "Does the little darling want a drink of water?" She took a beautiful gold lined cup, got it full of water and gave the beast a drink. He took half of it, slobbering all over the cup, and she drank the rest of it. Miss Dilletante, living down east, said 
with a sigh, "I must go to Florida this winter, for" Fido is ailing."

Could such things cultivate flowers and dogs, too? Here in Nebraska a banker sent for quite a bill of choice stock. He was willing to pay a good price. A year after he wrote me that though the stock seemed fine, yet it was not doing well. I went to see him, and a more woe-begone and bedraggled lot of stuff I never saw. The beautiful evergreens which should have been a pride and a joy were sick and dying.

"How many dogs do you keep?" I asked.

"Six."

"I should think so, by the way they have got in their work."

I was angry to see the finest trees that money could produce ruined in that way.

I heard J. W. Manning, the leading horticulturist of Massachusetts, say in the Horticultural Society of Boston, "tliat dogs ruined more evergreens and choice shrubs than all other causes combined. The dog, like death, loves a shining mark, and his peculiar system of irrigation is death. So if you are bound to cultivate dogs you might as well give up flowers. On the farm a good shepherd $\mathrm{dog}$ is often a necessity and he has generally enough to do to keep out of mischief.

I am often annoyed by great worthless dogs rushing in among my flowers and breaking or tearing them down. A dog has no more right to run at large than has a cow or horse.

It is sometimes pathetic to see a lady try to cul- 
tivate dogs and flowers in the same yard. She plants a bulb and the dear little doggie digs it up to see what it is. She has a choice bed of flowers and he makes his bed among them, tearing them down at his pleasure. Some people will persist in keeping a dog to keep off chicken thieves, and his bark will keep people awake for several blocks and he will rob the neighbors out of a thousand dollars worth of sleep to save a 50 cent chicken, when the chicken wasn't in any danger. Well, take your choice, dogs or flowers; but I would infinitely rather take the flowers. 


\section{CHAPTER VII.}

\section{PLANTING FOR FOLIAGE EFFECT.}

Landscape gardeners differ in taste and also in advice. Some plant a large number of trees with different shades in their leaves and some discard them altogether and insist on the universal green. But $\mathrm{Na}$ ture loves variety and gives it to us and we may as well use it.

\section{TREES OF SILVER FOLIAGE.}

The Bolleana Poplar is a charming tree, in form much like the Lombardy only more compact. The upper side of the leaves is green and the under side is white. I do not know how long lived it will be. It does not seem as vigorous as some others, and though hardy enough in resisting the cold it seems liable to disease.

The Abele also belongs to the poplar family. This was brought from Europe and though quite hardy it seldom makes a good straight tree, and sprouts as badly as the black locust.

The Nivea, more recently introduced, is a desirable tree. It is a more rapid grower, has larger leaves and a much better form.

The Russian Olive is hardy all over the northwest. It 
is very attractive where you can get it into shape. But growing it is the terror of the nurseryman. It requires more training, trimming and scolding than any other tree. It is inclined to sprawl and branch and grow bushy. But once they get it in shape, it is one of the finest we have. It has four silvery tints, one on the upper and another on the under side of the leaves. The growing twigs have yet another and the fruit is burnished silver. You watch it when the breeze is playing with it and mingling all these shades, and you will deem it one of the finest you ever saw. In the spring it is covered with little golden flowers and each one seems a tiny phial uncorked to fill all the air with a delicious fragrance. It is a delightful bee pasture and a grove of them is filled with the hum and roar of the delighted honey makers.

The Buffalo Berry belongs to the same eleagnus family. They have an affinity and I have grafted one onto the other successfully. It does not become as large a tree as the other. In some localities it bears enormously. This also has sweet scented flowers. The fruit is excellent, fully equal to our currants, with the advantage of holding on till midwinter. In some localities they are shy bearers, but on the University experiment grounds at St. Anthony Park the limbs were bending with their burdens of fruit.

The Regalis or Regal Willow is the most beautiful of all the willow family. Two kinds bear this name, but the real one has leaves burnished satiny silver, delicately veined. I think it will prove hardy anywhere. 
GOLDEN FOLIAGE.

The Van Gertii Golden Poplar seems to be related to the Carolina poplar and the cottonwood family. It is quite yellow while young but as the tree gets age the leaves turn to a pale green.

The English Golden Oak is a very popular tree. But I fear "hardy as an oak" will not mean much with it. I noticed it killed back some with me last winter.

The Golden Elm has very striking foliage. The color is clear and good. Most of these trees do not seem hardy when quite young, but as they get age I think they will be all right. These trees of rare foliage should be sheltered a little from our burning suns. I once secured some variegated catalpas. I saw them growing in Waukegan, Ill., and they were so charming I must have them. I planted them under the 100th meridian in Nebraska. No sooner did those beautiful leaves appear than they were burned to a crisp by the hot sun and drying winds.

A tree seems sometimes gifted with reason, and these seemed to say, "You don't like our style and we will try something else.". They put out no more variegated leares. The foliage was like the other catalpas, only a shade lighter. But they stayed on and the trees grew and kept up with the others.

There is a Golden Leaved Ash, but I have not tested it. There is also a golden variety of the silver maple; but I fear it would not be hardy in the west, for this 
species of maple is sensitive on being moved north very far. And the red maple, so popular in the east, is worthless in Nebraska.

The Golden Hop Tree is a success in most of the west. It is a variety of the great hop tree family. These grow wild in the Rockies and in many parts of the United States. They bear great clusters of hops. It is said they will take the place and do the work of the vine hops. They have a strong hop-like odor. The yellow type is fine, only it is somewhat difficult to get the tree up into good shape. It prefers to sprawl and grow bushy.

Among shrubs we have the golden elder, the yellow spiræa and syringa. Nature seems to love the gold. Along the foothills and up in the Rockies there is a marvelous prodigality of this color, as if they were hanging out the sign to tell of the rich gold fields beneath.

\section{TREES OF PURPLE FOLIAGE.}

The most conspicuous and attractive of them all is Rivers Beach. I secured some choice ones, for which I paid a good price and had them well sheltered. I bought also 500 common beach to bud the purple ones on. These wère under a screen of lath. They all got up the worst strike I ever saw. They utterly refused to grow and every one of them died. They joined the great procession of azalias and rhododendrons which had gone on before.

So you see the need of consulting your nurseryman if you would avoid serious losses. 
The Norway Maple is hardy in the west and this has three sports or variations that are worthy of all praise.

The Schwedlerii or Schwedler's Maple is a glory, in springtime unfolding a massive head of parple like a giant flower projected against the sky. It hardly seems possible that it could be only a tree. Afterwards the leaves turn to a dark green, while the new shoots are all the while showing the purple.

Geneva is another distinct variety of nearly the same color.

Then to match the Schwedlerii and balance up the seasons, we have the Reitenbach Maple, an excellent and striking variety of pyramidal form. The foliage is beautiful green in the spring, changing to purple in midsummer and then to glowing scarlet in the autumn. Here then we have three charming varieties from this one family of Norways.

The purple leafed birch does well also in the west. I have seen some fine speeimens in Northern Nebraska. There are two forms of elm that have purple leaves. In one case the leaf is a solid color and in the other case the foliage is edged with purple.

Among the shrubs we have the purple leafed barberry. Justly or unjustly the barberry family is charged with generating wheat rust just as the red cedar is accused of generating the apple rust.

PLANTING FOR AUTUMN EFFECT.

Our forests and mountains are famous for their splendid coloring after the first frosts have come. We 
have seen our western mountains clothed with marvelous tints and colors. Often excursions are planned from the Atlantic cities to the mountains of Vermont and New Hampshire for the magnificent nature paintings seen nowhere else. The whole landscape is like a canvas broad and vast on which pictures are painted which thrill the soul.

Said a gentleman to an English visitor as they were standing before a scene of surpassing beauty, when such glowirg colors under the clear sky made the whole glorious mountain seem a vast bouquet of loveliness: "Did you ever see anything like that?" "Well," was the reply, "don't you think it is a little tawdry?" Thus insulting nature in her glorious temple. $\mathrm{He}$ was probably brother to the man who stood by Niagara, when the thundering waters were making the earth tremble. "Did you ever see anything like that? Such mighty volumes falling into such a tremendous abyss." "Well, what's to hinder?" was his only reply. But people are not all kickers and cynics. We love the beautiful. And when Nature puts on her autumn dress we can but admire her. It is like the wild rollicking festival of the Latin countries just before the world sobers down to Lent.

It is well to plant for this color effect. There are many things that will greatly. aid us and our grounds are large enough. We can have much enjoyment along this line. Where the hard maples can be made to grow you will see them with their crowns of gold. The wild cherry is dressed in red and crimson. The black haw 
is very attractive in its coat of many colors. The spiræa arguta, the first to bloom in the spring, makes its exit into winter with sumptuous garments of gold, red and purple. This great show is Nature's last attempt to enliven the world when the flowers are all gone and the leaves begin to fall, and it is well to help her with her last carnival of colors. 


\section{CHAP'TER VIII.}

\section{THE LILAC.}

The name comes from the Persian word, lilag, a flower. The common kind has been in cultivation for ages. It probably originated in Persia. Nurserymen and botanists now call these syringas, and the syringas are classed as Philadelphus; but as we are writing for the common people we will use their terms.

If one should ask the ordinary observer how many kinds there were he would answer three, the common purple, the white and the Persian. There are over 130 kinds now in cultivation, and the number is increasing by hybridizing. Why this great family of hardy ornamentals has been ignored and neglected all these years, it is hard to understand, for they are exactly what is needed to cheer up the great northwest. They are among the hardiest things we have, and there is hardly one in the large collection but what will thrive in Manitoba. The time of flowering reaches from early spring till about the first of July, and the variety of foliage is something wonderful, varying from the large corrugated leaves of the Bretschneider to the delicate foliage of the Pekinensis and the feathery leaves of the cut-leafed Persian. We have secured a photo of half a dozen kinds to show the rich variety. 


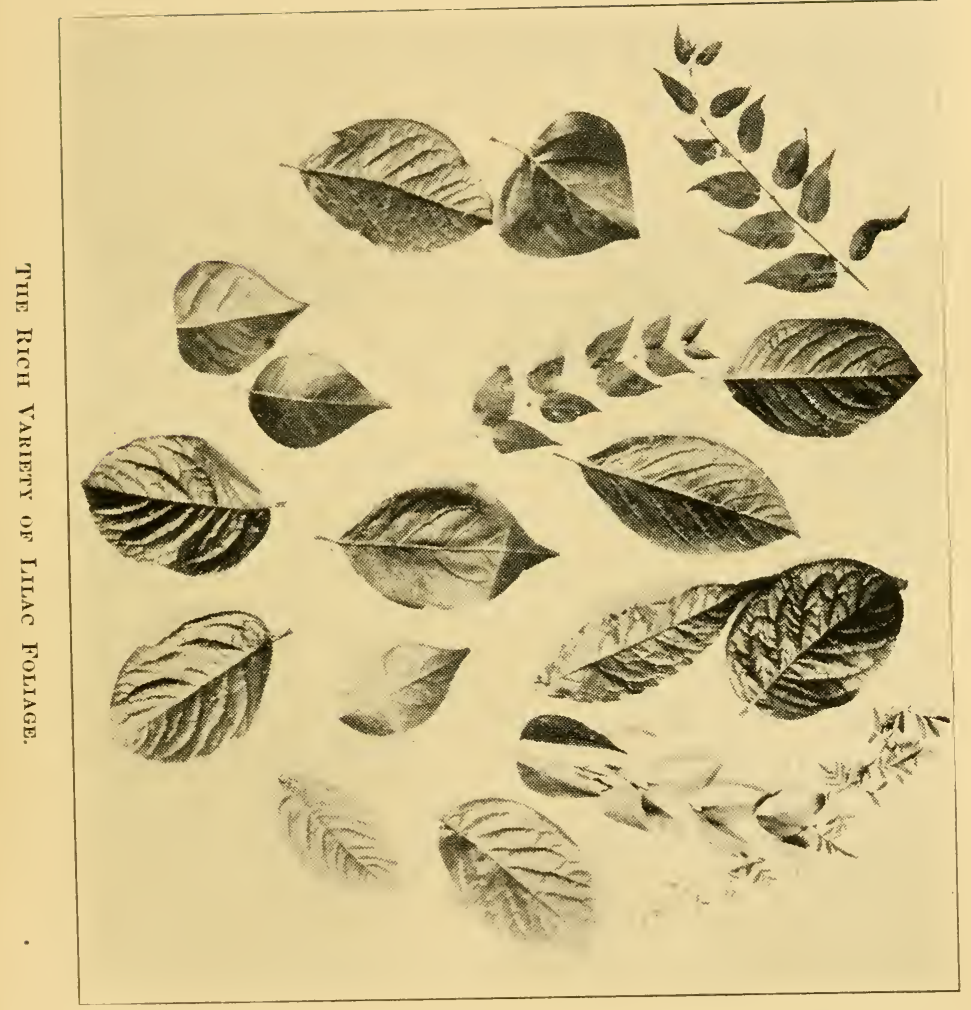




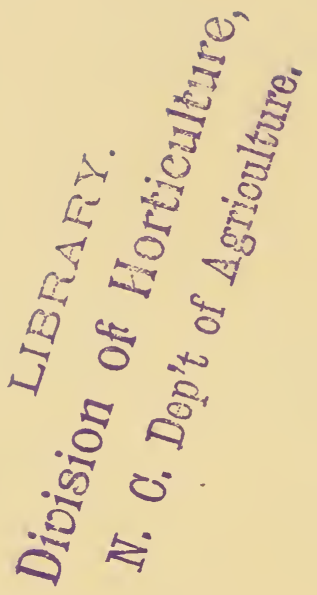


In color the blossoms range from snowy white to purple, and if you have a good collection you will have continuous bloom till the last of June.

The Vulgaris is the kind generally used in the west. It is rather a shy bloomer in most places. They are notorious for sprouting, and wander out from the parent plant almost as bad as the Canada thistle. People put up with their vagaries on account of their sweet and generous blooms, but in this respect they are far surpassed by some of the more modern sorts. Charles the Tenth ranks among the best as a great bloomer. Belonging to the Vulgaris family it is inclined to sprout, however. There are many striking variations in this Vulgaris family, and, if growing near others, secdlings from them will show quite a variation. We have known parties to raise plants from seeds of the common ones, but there is little chance of improvement, for "like begets like." At the Brandon station in Manitoba the superintendent has a hedge raised from the seed of Charles the Tenth, and I noted quite a variation in the size of the bushes and in the foliage also, showing that there was a mixed parentage somewhere. Mr. Bedford said that there was quite a difference in the blossoms also, that some were even superior to the parent, which was saying a good deal.

The Persians. These have slender branches and are sure bloomers. They do not sprout like the Vulgaris, yet they multiply from the stool, and if these are taken up and pulled apart a single clump will often produce a dozen. 
There are three kinds: The cut-leafed, the common purple, and the white - the blossoms are not pure white, but nearly so; they have a slight tint. The cut-leafed is one of the most delicate and beautiful plants in existence. The foliage alone is of such a peculiar type that of itself would be a sufficient recommendation, but added to this it has sweet purple blossoms. Closely allied to the Persian, and hard to distinguish from it, is the Rothunogensis, sometimes called the Rouen lilac, because it originated there. There are two types of this, the purple and the white. They are hardy and vigorous, as well as profuse bloomers. I imported quite a lot from France. One trouble with the whites is, they are very tardy bloomers. The common white, the virginal, and grandiflora alba, all want to take their time. But the Rothmogensis alba commences almost at the ground. The first year from France some of them showed bloom when only twelve to eighteen inches high, and the next year they were covered with flowers when only two feet tall. I am highly pleased with them.

The Emodi is from the Himalayas. It is a strong, vigorous shrub, having enormous leaves for a lilac, and blooms in June. There is a species of this called the Variegated. I secured some, and am highly pleased with them. In the dry climate of the west, with hot winds and hot suns, most trees and shrubs of variegated foliage are sadly affected. However, this does not seem to mind it, but preserves its rich coloring through it all. I think this is a fine acquisition, and there will be a great demand for it. 
The Oblata is from China. It has large, thick, heavy, heart-shaped leaves, which never mildew. It. blooms several days earlier than any of the rest, heading the whole procession by at least a week. It has another attraction: it holds its foliage a long time, and in the fall takes on a rich, dark russet color. Like the Spirra Arguta, it has attractions for both ends of the season. We have two other remarkable ones from China. One is the Ligustriana, resembling the Privet. It has long, slender branches and rather small leaves. It grows fifteen to twenty feet high. The flowers, which are yellowish white, hang in large clusters, usually in pairs. This is quite hardy, and seems easy of propagation. There is a variety of this called Argentia, said to have silver leaves. I have never seen this, and do not know how the foliage would stand our climate.

The Tree Lilacs. Securing these has been one of the triumphs of horticulture. They are perfectly hardy all through the west.

The Pekinensis. Some fifteen years ago I planted some of these under the 100th meridian, in Nebraska, where we have one of the most trying climates in the world. We had three consecutive years of terrible drouth, and the American siroccos, the hot winds of the plains, prevailed to such an extent that many trees were wiped out of existence. Six kinds of poplars and as many kinds of willows were entirely killed. I left the place, and the lilacs were left to the weeds. Yet the Pekinensis was cheerful and smiling with bloom through it all, and when the mercury dropped to 35 
below it was all the same. I have a fine grove of these trees, now six years old. Some of them are about a foot in circumference, and fifteen feet tall. They are trees, not shrubs. They do not bloom as early as the bush lilacs, but make up for lost time when they get at it. They have great spikes of snow white, honey scented flowers. If they never bloomed at all they would be worth planting on account of their gracefully drooping branches and fine foliage. The leaves are small, and those on the young shoots have a purplish tinge. They are yet scarce and high, but it pays to have them. In the future they will be used for avenues, where their splendid bloom and pendulous branches will be very attractive. They propagate readily by grafting them on the root of the common lilac. Only note this: If you use the lateral roots of the Vulgaris they will sprout like the mischief. If you take the tap roots, they cannot sprout. You graft just as the nurseryman grafts his apples in winter-a piece of scion and a piece of root to match. Make a splice or lip graft, and wind with waxed thread. Sometimes, when compelled to use a lateral root, I have taken them up after the first year and cut off the Vulgaris root, leaving only those thrown out from the scion. By doing this you have them on their own roots. Grafted trees should be planted deep, so you can get roots from the scion of the tree itself. Otherwise if you depend on the Vulgaris root your tree will be dwarfed. I much prefer to sow the seed and draw on my friends east for it. Then we have a tree on its own roots. 


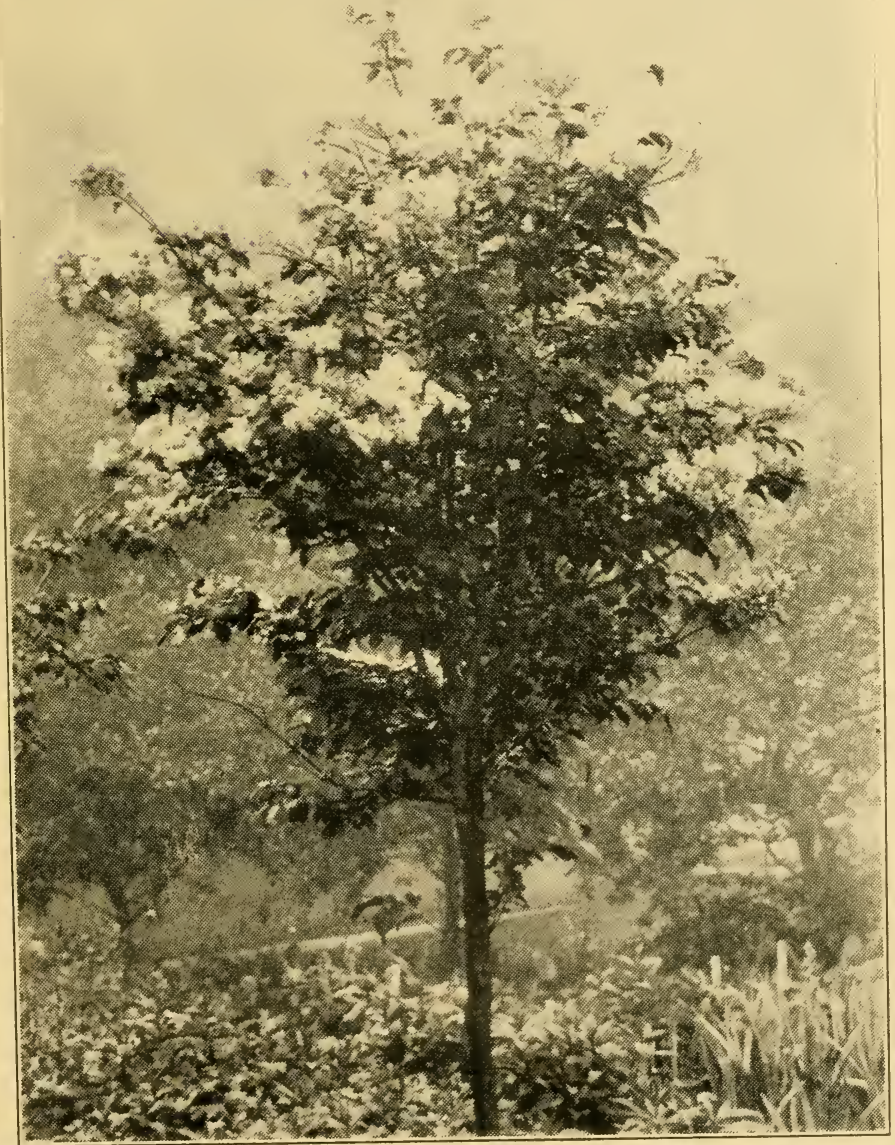

Japay Tree Lilac on the Grounds of C. S. Harrison, of York, Nebraska. 

Right here let me say that the root of the Persian lilac is the best to graft on of anything I ever tried. Both the tree lilacs, and almost all the other kinds, take well on it, and it does not sprout like the Vulgaris. You must train these trees to a single stem. If not, they will branch too low, or be bushy. It is not a hard matter to do this. They will grow about as fast and as large as our native ash. They require rich ground and good cultivation. I know several people who got small trees, and put them in the sod, and then complained that they did not do well. If any one doubts the ability of the lilacs to make trees, let him see the splendid grove of them here in York.

The Syringa Japonica or Japan Lilac. When this was first introduced into the east it created quite a furor, and the trees rapidly sold for \$s each. T'he Shady Hill Nursery sent to Japan for a bushel of seed, and commenced growing them on a large scale. One grew from seed, in the Arnold Arboritum, of Bostori, in twenty years, to a height of thirty feet, and it was tl.irty inches around three feet from the ground. I measured it myself. It is said that in their native mountains of Japan they grow to be a foot through and fifty feet tall. I judge this tree would not stop till it reached those dimensions. They are hardy in the north. Prof. Green has some fine ones on the experiment grounds of the Minnesota University, and he has raised hundreds from the seeds gathered from them. They can readily be grafted on the root of the common Persian lilac. 
The Villosa is a large, strong growing lilac from Japan. You might call it half tree. I supposed this would be the tenderest of all, but I found it growing and thriving at Brandon, Manitoba. It has a purple blossom in June. I wish some one would graft these on the tree lilac and then plant the seed. I am sure desirable results would be secured. At first this one does not impress you. You see a few blooms, not extra large. But some summer you will be astonished to find the whole bush turned to bloom, one great bouquet of fragrant loveliness. This does not graft well, not even on its own roots, any more than does the snowball; but you can layer it just as you would the snowball, with the same results.

Double Flowers. Following the order of development we now have many lilacs with double flowers. The same results are reached here as with the rose, carnation and dahlia, and we really know but little of what is before us, but from what has been accomplished along these lines we may expect great things. We have among the doubles Senator Volland, Jean Bart, Emile Lemoine, De Humbolt, Linne, Madame Iuemoine and many others.

The Best Kinds. From my own experience at the York experiment station, I would recommend all the Persians, the two Rothmogensis, Dr. Bretschneider, Josekae, the Emodi, green and variegated, Villosa, Charles the Tenth, Pyramidalis, Senator Volland, Glori d' Croncles, Ligustriana, and the two tree lilacs. 
It is a shame to let the front yard go unadorned when such splendid things are waiting your beck to take their places as part of the family. They are ready to do their utmost to cheer and enliven the home. 


\section{CHAPTER IX.}

\section{THE VIBURNUM OR SNOWBALL.}

This is quite a numerous and interesting family. Most people suppose there is only one, and that the old kind with which we are so familiar.

This is called Viburnum Sterilis. There are no seeds following the great double flowers which appear in spring time. It generally takes the bush form, though with a little care it can be trained into a tree, and when it is 15 feet tall, with massive head, covered with a profusion of snowy blooms, it is exceedingly attractive. These are ordinarily propagated by layers.

Some keep bushes for that purpose. Pull down the lower branches and cover them with six inches of earth. Allow no weeds to grow near and in the fall you will have nice, well rooted plants. These are cut off and planted by themsclves. I have sometimes raised a dozen from a single bush. No home should be without these snowballs. They are hardy and great bloomers.

Viburnum Opulis is the high bush cranberry so common in the Minnesota forests. I well remember in the early days that it was our delight in winter to come upon clumps of these berries in that northern land when fruit was scarce and high. One trouble in rais- 
ing this kind has been this: 'They grow in Europe and in some of the eastern states and for a long time I was disappointed in them for they were not hardy; but, securing them from the north, they were all right. I never saw a finer collection than Professor Green has at St. Anthony Park. He went into the woods and secured the most prolific he could find, and propagated from these, and they were very attractive. There were great clusters of bright red berries hanging on the bushes wherever there was a chance; in some cases bending down the branches and making the little trees graceful weepers. They do better shaded from the sun, and will do best on the north side of a grove. The Sterilis is a variation from this species. They are alike in foliage and the habit of growth is much the same. Here you have a plant highly useful as well as exceedingly beautiful. You have blossoms in the spring, and the whole bush in the fall is a splendicl bouquet, with its glowing red, and the foliage of both species in the fall has the richest of tints, making a combination of effects which cannot but be appreciated. You secure these by sowing the seeds and letting them remain two winters. Or buy the bushes ready grown.

Viburnum C'assinoides has branches covered with white flowers in June, followed by black berries in the fall.

Dentatum or Dentated Leafed Viburnum proves to be very hardy in Nebraska, and I presume will be all over the Northwest. The leaves of deep green are large, dented, wrinkled and corrugated, making them 
very attractive. They have white flowers in the spring, followed by great clusters of berries of shining blue. They prove hardy in Manitoba.

Viburnum Lentago is a native species, growing from Maine to Georgia. It is a handsome, low growing tree of great beauty. I do not know whether it has been tested fully in the West. This is called the sweet viburnum or sheep berry. Its flowers are creamy white, and very fragrant. The foliage is light glossy green. It has a profusion of berries in the fall.

Lantanoides is another small and shapely tree belonging to this family.

Prunifolium or the black haw also belongs in this list, and it is interesting to know that two of the important branches of this family are natives of the North, and "hardy as the oak."

With what avidity the schoolboy strays from the direct path going home to regale himself with the ripe rich fruit of the black haw. Plant masses of them. Flower and fruit are attractive, and the autumn coloring is simply gorgeous.

Plicatum is from Japan or North China. It is a marvelous bloomer, rivaling, if possible, the old Sterilis. I have seen these bushes with great massive mounds of snowy bloom in the East; but I have never succeeded with them in the West unless they had shelter from the sun. How far north they have been tested I cannot say. Many things will thrive in northern Minnesota which cannot endure the heat of Nebraska and Kansas. The Tomentosum is a beautiful single form of the 
Plicatum. 'I was in Boston when a bunch of these was brought into Horticultural Hall. It created quite a furor. The branch was one mass of blocm of pure delicate white. "What is it?" "What can it be?" were the queries which surrounded it. No one knew. Just then Jackson Dawson, superintendent of Arnold Arboretum, came in. He knows everything. Few plants of the temperate zone ever escape him. He told them what it was. T. C. Thurlow is a prominent florist and keen as a briar. He went home and examined lis foreign catalogues and found a lot listed over in France. He sent and bought the whole lot. He sold quite a quantity to some florists who cut a large amount of them green to propagate in a green house. I remember I was there and helped cut great basket loads for the purpose of propagation. This was some years ago. They are now very well distributed.

I have not yet tested them, but will try to do so. I am sure, however, that like the Plicatum, they will need some shelter from the sun.

Both these last, like the Sterilis, are produced by layering.

\section{OTHER SHRUBS OF VALUE.}

The Euonymus. This is also called burning bush and spindle tree. The American species is the Wahoo. There is a town of this name in Nebraska, so called, I believe, on account of the fine clumps of burning bush near it. In the eastern part of Nebraska you often see them growing wild along the streams. There 
are some beautiful specimens in my garden across the road from where I write. The limbs are covered with scarlet fruit. They are desirable-as shrubs, with their flowers in the spring, their rich foliage in summer, and their showy berries in the autumn. When the leaves fall the whole tree is simply ablaze with its profusion of berries, giving a cheerful cast to the somber tints and falling leaves. It is propagated from seeds, which lie in the ground two years, and also from root offsets. The European varicty is worthless in the West. I have had them kill to the ground. There is a creeping type of the Euonymous extremely beautiful in the East, with its richly rariegated leares, which, in favorable localities, will stay on all winter. But it is of no use in the West. I have tried it carefully under screen of lath. It is bound to die.

The Hydringea. There are several species of this, some of which make valuable house plants. But the only one of any merit for out doors is the Paniculata Grandiflora.

There is probably no plant, shrub or bush that yields such a profusion of immense flowers as this in proportion to the height of the bush. The curious thing about it is, it is not called hardy at the Kew gardens in the mild climate of England, and it cannot endure the intense heat and dry winters of our western plains, and yet in Minneapolis and St. Paul it will grow to a small sized tree, and be glorious with its great burden of flowers. No yard is complete without it. It seems to do better planted in masses than when set out alone. 
There are many things inanimate which appear to be of a social nature, and they love company of their orn. kind. So now these are set out mostly in clumps of from six to twelve, and you have a perfect bank of flowers. If the ground is good, and they have the best of care, the flowers will sometimes be as large as a mian's head. They are white at first, and, as they get age, they put on a slightly reddish tint. They seem to know how to continue in bloom a long time, and then die gracefully.

They are usually propagated in the hot-house from green cuttings. They can be increased, however, by layers.

You can take quite a branching bush and plant it deep so the branches will be under ground, and they will all take root, when they can be cut off and planted by themselves. They are generally propagated on a large scale in France and sent from there in immense lots when they are small. I have often used these imported ones. There will be some loss, and it takes time. It is better to get good strong bushes from your nurseryman.

The Sambucus or Elder. If we had to import our Elder from Europe, and pay a high price for it, with its great, massive blooms in spring time and flat masses of dark berries in the fall, almost as large as dinner plates, we would think a good deal of it; but as it is, it is generally neglected. If, however, you have room enough and wish a large wild garden, then you will have a place for it. There are twelve varieties of 
Sambucus in cultivation. Some, like Pyramidalis, are too tender; also the fern leafed. The weeping form is also tender. The cut leafed seems hardy, and a rank grower. Very attractive with its peculiar leaves. One type, with red berries, grows in the Rockies. The Golden Elder is hardy and desirable. The variegated leafed is very striking. It does fairly well in $\mathrm{Ne}$ braska. I do not know how far north it can be moved. Plumosa is a cut leafed, weeping variety; and then there is the golden cut leafed.

The whole family are as easily propagated as willows, growing readily from cuttings. This is not generally known.

Some use the golden for hedges. It makes a good windbreak, but, of course, is not strong enough for a fence. This and the cut leafed are: rapid growers, and would make quite a hedge in a short time. 


\section{CHAPTER X.}

\section{THE SYRINGA, OR PHILADELPHUS.}

Philadelphus was an Egyptian king in the long ago, and in some way his name is fastened on these shrubs. Whether he wore the flowers on his hat or in his buttonhole, or decorated his house with them we cannot tell, but it has stuck to them ever since, and will probably to the end of time. They are sometimes called Mock Orange, because the flowers have the perfume of orange blossoms.

They are an exceedingly vigorous and hardy race, and as they are very reasonable in price, no farm or house lot should be without them.

The little old sweet scented syringa is most generally known. The flowers are small and bear no comparison with those of more recent introduction.

There are several distinct families of these shrubs, and as they grow readily from seed they have a tendency to hybridize, and so new varieties are coming to the front. They have fine foliage, and often grow to the height of twelve or fifteen feet, and when they are covered with their snowy bloom they are very attractive. Some have an early and some a later time of flowering, and so there is quite a succession of bloom. Some of these shrubs are natives of Central Europe; some are 
from Japan; some come from the Himalayan mountains, from whence we derive so many choice shrubs and flowers; some are found growing in the Virginia mountains; and in the Rockies we have the Rubus Deliciosus, which is closely allied. Its form is like the syringa, though it bears berries. In the spring it is like a snowbank of beautiful white roses. It is extremely hardy; but its place is by a pond or stream of water, or if on high ground it must be well watered. It is not a success unless it can have wet feet. We give a list of some of the varieties:

The Coronaris or Garland. This is a pure white flower of peculiar form-four full blossoms and on the top of them another, making a minature crown-hence the name. Give it good cultivation and it has glorious sweet scented blossoms.

Flore Pleno is a variety partly double, and very fragrant.

Nanus is of a dwarf habit; a low, compact bush and very shy bearer-used mostly as a border plant.

Zyheri. I secured some of these last spring and am watching them closely. They seem quite vigorous, and well adapted to our climate, and the entire family stood the terrible heat of summer without flinching. This has a large odorless flower, and is very late-making it very valuable in lengthening the procession.

Crolden Leafed Syringa. This is a beautiful plant, somewhat dwarfish in habit. It retains its golden color all through the season. Last summer the leaves scorched a little in the burning sun. It is wall to keep 
a treasure like this a little in the shade, when it will be all you can ask. Aside from the golden color it has lovely white flowers. These should be planted where they can show marked contrast with the green of others, or where they can stand by some purple leafed shrubs. We must learn to plant for color effect.

The Gordonianus is a yery prince of the family, a vigorous grower, slightly fragrant and blooms late.

Speciosissimus is of dwarf habit, forming a bush about three feet tall, which is covered with large white, sweet scented flowers.

Laxus has an upright habit of growth. This also has good sized flowers, richly perfumed, and it is a very valuable sort.

Avalanche. This was sent out a few years ago as a new variety. A dwarf loaded and smothered with flowers. I sent 50 cents for one and got a dwarf sure. It was so much of a dwarf it could hardly be discovered with the naked eye. But I planted the little thing, and it has done well, and though it has not flowered yet, I have great hopes of it.

Lemoine's Dwarf was a companion of the Avalanch, and much like it in form and in the promise of flowers. That was very small, but the best of care has brought it out and it is a plant of promise.

Lemoinc's Erecta Syringa is a charming variety of upright growtli. It has small fragrant flowers of yellowish white, completely covering the bush.

Microphyllus has very small leaves, which show well 
in contrast with the larger ones of other kinds. This is a dainty little thing with tiny white blossoms.

Nivalis has scentless flowers, the stamens of which are cream colored, and this gives the entire blossom an almost snowy white appearance.

Pentimensis is, of course, a Chinaman. It has creamy white bloom which is very fragrant.

Primulaeflorus is remarkable in that the flowers are well nigh double and are delicate white.

Hoary Leafed Syringa has large downy foliage as well as large white blossoms, which are late, thus lengthening the season.

Willow Leafed Syringa is very unique in that it has borrowed the leaves of the willow for its clothing. The leaves are curled at the edges. It is of a dwarf habit.

Speciosus is of distinct and well marked habit with late flowers.

Yokohama is from Japan. It is of upright and compact form, with a sort of plaited foliage. Flowers very odorous, making a very desirable plant.

We notice that quite recently there have appeared important additions to this family. I have just received a catalogue from a large nursery in France and have sent in an order for the following to test them in Nebraska:

Ketelor's Syringa, which is double flowering. Flowers by nature are single. Double flowers are the work of nature and art. The tendency of improved flowers is to grow double and larger.

Glorious as syringas are, we believe there is a splen- 
did future for them, and when bees are plenty to mix the pollen, and you have the full group by planting the seeds, you stand a good show for something new and fine.

We notice next Sutzman's Syringa, then Silver Bell, which comes out with great promise; also Candalabre, noted as being a very free bloomer. Then there is the Mantle of Ermine and Mount Blane.

Grandiflorus has a very large pure white flower, somewhat fragrant. It is a very vigorous grower.

Years ago I was on the grounds of T. C. Thurlow, of West Newbury, Mass., and there I saw a new kind with immense blossoms. They had been imported from: France. I got him to send me some enttings the next winter. But two of them lived. They prove to be the strongest grower's of all. I saw one sprout had made ten feet in a single year. The flowers were two inches across, and they hung in chains from the branches. I never saw anything like it. They were not the Grandiflorus. They were much larger. I named them French Mammoth. They will do in Nebraska, though the tops killed back some. I may send some to Professor Green and have him test them.

In the Arnold Arboretum I saw one, the blossoms of which were very large, and, in giving the origin, Mr. Dawson told me he had raised it from seed. It bore striking resemblance to the French one, only the bush was not quite so vigorous.

Lemoine of France has been a very successful horticulturist along many lines. He is almost as much of a 
wizard as our own Burbank. He originated Avalanche Lemoine and Lemoine Erecta, all of dwarf habit, and now I have just secured for testing newer kinds.

Boule d'Argent, with flowers quite double, with delicate fragrance.

Candelabre is a dwarf plant, very prolific bloomer, with large white flowers.

Coulteri is another new kind-short, erect habit, flowers large, solitary at the ends of the branches, pure white, and of great substance:

Fantaisie is described as an altogether distinct variety - a very prolific bloomer, flowers pure white, pale rose in the center, and delightfully fragrant.

Fimbriatus is a very unique variety, "branches arched, covered with large white flowers deeply toothed."

Gerbe de Neigo has flowers very large, and so many of them the branches bend beneath their weight.

Manteare d'Hermine has flower's double and semidouble, creamy white, spread up and down the branches.

Perle Blanch forms a dense shrub with large double pure white flowers.

So we see the evolution under human skill of the single transformed to the double, and in time these will grow fuller and larger.

From this review what a splendid family we have to chose from, and what an addition to parks and home grounds. 


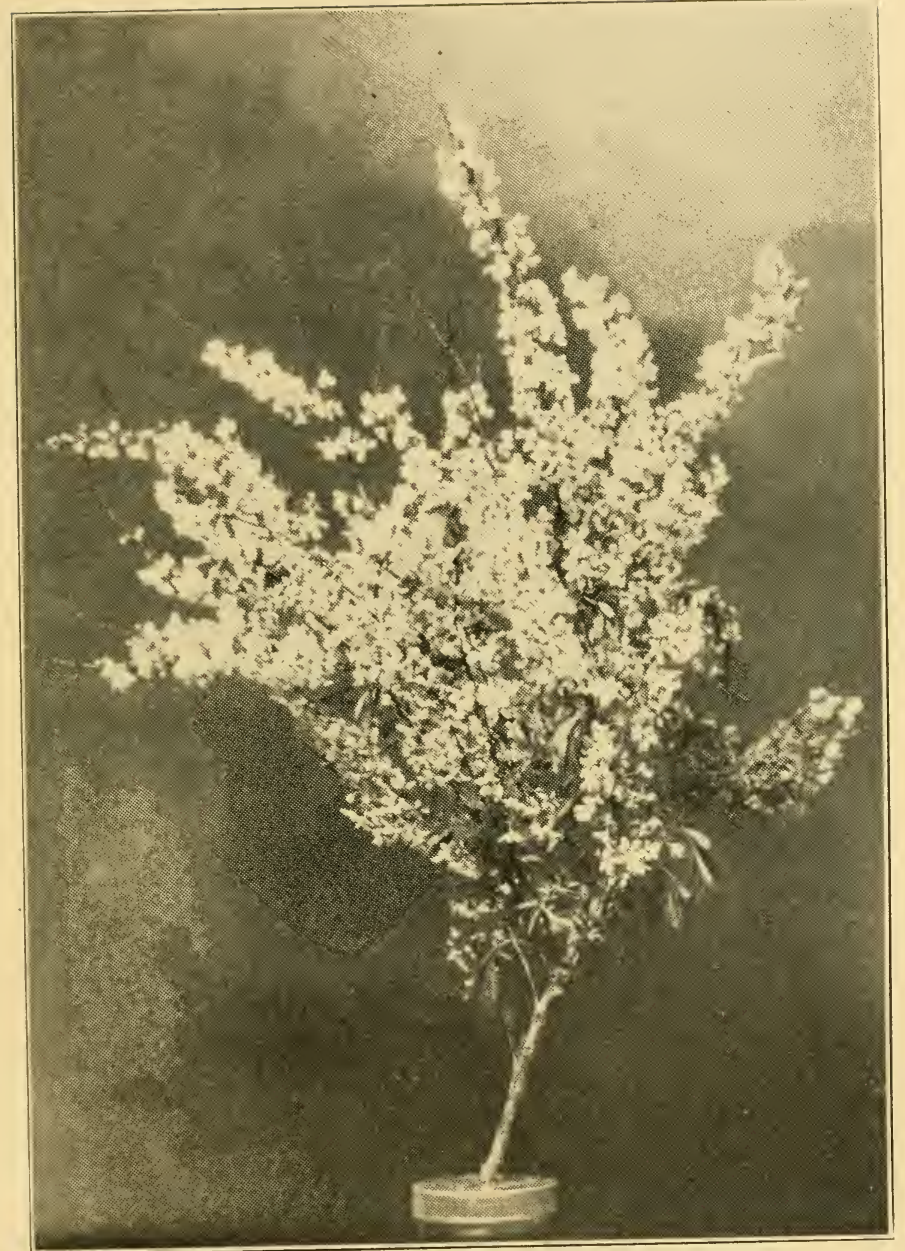

Spirea Arguta. 



\section{CHAPTER XI.}

\section{SPIRAEAS.}

Just as I am writing this chapter, Bulletin 47, on trees and shrubs tested in northwest Canada, comes to me from the director, Dr. Saunders. I am very glad to welcome it, for we want the benefit of their patient research, and things that will thrive in those cold regions will do further south.

Their experience corresponds with that of the York Experiment Station in that we cannot raise any of the Deutzias.

We have been at great expense in testing these, and have to throw them out altogether. The result is the same with the Beeches. In no case have they passed the winter in either station.

With the Spireas it is different. There are about fifty varieties of this family. There is a wide range both in foliage and bloom. Planted for a succession, we have flowers nearly or quite all summer. They are very easily propagated. Many grow from cuttings, and the rest multiply by off-shoots very rapidly. So there is no reason why they should not be had in abundance.

The first to bloom is the Arguta, said to be a cross between Thunbergii and Multiflora. This blooms with the tulips. It is in such haste to blossom that it does 
not wait for the leaves, but opens a perfect snowdrift of white. Having quite a hedge row of them the passers-by in the spring would stop to admire them and ask what they were. They are the heralds which head the procession of beauty. The leaves are fine and delicate, and remain on the bushes till December, and before they fall they change into garments so rich in the varied colors of autumn that a row of them seems to be the last of the flowers.

No collection should be without them.

The Thunbergii is very delicate in appearance-the leaves are small and the tiny white blooms make it "a little daisy" among the group.

Prunifolia, or Bridal Wreath blooms next. This is sometimes called the button flower, for it is shaped like a small white button. It has a double blossom like a tiny rose. This is a profuse bloomer, but is not quite as hardy as some of the rest. They bloom about the first of May, the flowers hanging in clusters along the stems before the leaves appear.

Van Houttei. This is deservedly a great favorite. It seems hardy everywhere, and is such a wholesale bloomer it is one mound of beauty. It propagates readily, both from off-shoots and cuttings, and can be had for hedges. It is much used by the railroad gardeners of the East to cover embankments and hide rocks, and when in full bloom it is like riding beside snowbanks of fragrant beauty.

Callosa has great masses of pink flowers growing in large flat heads, in shape much like the blooms of our 
native elder. The blossoms appear early in June and continue several weeks.

Callosa Alba has white flowers much the shape of the latter, but not quite so large. It blooms later, and retains its beauty a long time. This is a very desirable plant.

Superba belongs to this same Callosa family. It is dwarfish in growth, with pinkish white flowers that appear in June.

Bumalda is a vigorous little dwarf from Japan. It often kills to the ground, but does not stop for a trifle like that, but is up and at it again, and in June is clothed with a profusion of pink flowers in flat clusters, and then it keeps at it all summer. It never grows very tall, and is useful for the border and placing in front of the taller ones.

ANTHONY WATERER.

There is probably a greater demand for this than any other, unless it is the Van Houttei. It is a seedling of the Bumalda, and is much like it in form and habit and shape of the flowers. While the former are pale pink, these are crimson in the bud and continue so some time after opening. Then they turn to red or deep pink. If the flowers are removed they will continue to bloom nearly all summer. These, like the parent, often kill down in winter, but throw up new shoots and are ready for business in June and on till frosts. 
Rotundifolia has round leaves of dark green color, with a graceful habit of growth and cluster of white flowers in June.

Opulifolia is indeed opulent in its foliage. This is the giant among the spiræas, and seems hardy everywhere. I saw it growing all right in Manitoba. This is called the tree spiræa. It is an easy matter to train it into tree form, when it presents a fine appearance. At this station we have had them grow six feet the first year from cuttings. The flowers are white at first, and are in the form of hemispheres. Put two together and you have a ball about one and a half inches in diameter. Eventually the blossoms turn to gold. They hang on a long time, seerling heavily. These seeds grow readily.

A urea is a rariety of the Opulifolia. It is not quite so rank a grower. Its golden leaves contrast richly with the neighboring green. The flowers are of the same color and form as those of the parent.

Sorbifolia, or ash leafed, is a unique and charming shrub about six feet tall. The foliage is very fine, and the bush is surmounted by massive spikes of flowers of grayish white.

Reevesii. This grows to be four feet tall, and has beantiful clusters of white flowers the last of May.

Double Recresii. While the last-named are single, these have double white flowers, which appear a little later. Both varieties are compact in their habit, and have slender branches.

Billardii has spikes of rosy pink flowers and Douglassi is much of the same form. 
The Dumosa grows in the Rockies. It has massive spikes of grayish white flowers.

\section{A MIOUND OF SPIRAEAS.}

Where you have room you can plant with fine effect in the following manner: Put. Opulifolia in the center. The next in vigor of growth would be the Aurea. Then Van Houttei. Next Bridal Wreath. Then a circle of Arguta. Next a rim of Thumbergi. Then Bumulda or Anthony Waterer. If you have room you can put in other sorts. Then you have a beautiful mound with a rich rariety of foliage and also a succession of flowers from early spring till fall.

Herbaceous Spiraas. These have strong roots, but the tops are annual, and kill down like those of the paeony. I think you can count on their being hardy everywhere. If there is any doubt about it, mulch well in winter.

Lobuta, sometimes called Queen of the Prairies, is a stately plant. It grows in the meadows of Pennsylvania. The flowers, which are of peach color, are very fine. It is much improved by cultivation.

The Astilbe is from Japan. I fine plant, with pure white flowers, in large branching panicles. We have tested this, and it is all right.

The Aruncus or Goat's Beard, is a fine species, growing wild in the Catskill and Allegheny mountains.

Palmata is a fine rariety, and then there is the $U l$ maria, a double sort. The IIumboldtii has greenish blossoms. 
Other Plants. The Hibiscus kills down in winter, but comes up in the spring. It has broad leaves and large, white flowers, with crimson eyes. This race is distinct from the other Hibiscus family, which is called the Althea. The kind we are describing has strong roots, which push up their sprouts with great vigor in the spring. They bear immense masses of blossoms.

The Polygonum is somewhat of this habit, making a vigorous growth in summer, giving quite a profusion of bloom, and killing down in winter. There are two varieties on the Minnesota experiment grounds.

The common name is the Mountain Fleece. One species was introduced from the Himalaya mountains, whence we derive so many of our choice shrubs.

Incidentally, I would say that neither the Altheas nor Wegelias are hardy in the great Northwest.

\section{THE ROSE.}

Personally I do not pay so much attention to this flower as to the paenny, which is rapidly taking its place, being much hardier, much more easily cultivated, and as satisfactory every way. Yet there are thousands of people who will prefer the rose to every other flower.

No other flower has had such a history. It reaches back into the far-off ages, and you find it in writings both sacred and profane.

The Romans made much use of it in their social gatherings. Roses were placed over the principal entrance, and he who passed under them silently bound himself not to reveal anything that was said or done 
at the feast. Of course, if wine flowed frecly, there might be scenes and sayings which would not look well if given publicity, and he that passed under the rose must not gossip. The "Sub Rosa" now used means "keep mum."

There are about 100 native species. You find them in Europe, Asia, and Africa. Even in Iceland and Greenland, and other parts of the far north, they are found. In our own land we have many members of this great family,- the wild ones always of the single type.

The Contifolia (hundred leaves) or Cabbage Rose is one of the oldest members of the family. It is a native of eastern Caucasus, and is supposed to be the one mentioned by Pliny, the old Roman historian. A very numerous family have been produced between this and the Gallicia, or Provence roses. These are all beautiful and fragrant, and the flowers have a compact and cabbage-like form.

The Moss Rose is supposed to be a sport of the Provenco rose, for seedlings of this variety will often be found of that type.

The Damascus Rose is an old favorite, having been introduced from Syria. It is now extensively cultivated in the gardens about the ancient city of Damascus for the purpose of making rose water and the Attar of Roses.

The Sweet Briar is a native of England. This has a delightful fragrance of foliage as well as of the flow- 
ers. It has been crossed with other varieties so that we have now many of a double form.

The Bankinia Rose was introduced from China in the early part of the last century, and was named in honor of Lady Banks.

TIIE JAPANESE ROSES.

We have three of the single type that are marvels of beauty.

ROSA RUGOSA.

Probably no recent introduction has had a larger run than this. There are two varieties, the white and red. Though the flowers are single, yet they are very large and clear in color, and they are perpetual bloomers. If you have a row of them you will always, from spring till the frosts of autumn, find flowers on them.

If the bush had no blooms, it would pay to plant it for ormament alone. The leaves are glistening polished green, large, deeply wrinkled and corrugated. The bush is strong, vigorous and hardy, thriving as far north as Manitoba. There is a great demand for this flower. Planted singly, in masses, or hedges, it is very satisfactory. One peculiarity is its enormous bright red seedballs,--like red crab apples,-which hang on a long time, making a fine display even after the leaves have fallen.

Rubifolia has reddish leaves. It is a strong grower and a prolific bloomer, the foliage contrasting beautifully with the neighboring green. 
Multiflora is a marvel in blooming time. The bush is literally covered with a flood of light pink flowers. I have been watching these three varieties in our experiment station in York and find them every way satisfactory. All of them are hardy, vigorous and prolific bloomers.

They are easily raised from seed. Get a few plants, take the seedballs and rub off the pulp, put them in sand and let them freeze, or plant in the fall. Those in sand you plant first thing in the spring. They come up readily, and you will soon have enough for masses or hedges. They are so easily raised no one should be without them.

\section{CLIMBING ROSES.}

These are a numerous family. We have Qucen of the Prairies, Seven Sisters, Baltimore Belle, Tennessee Belle, and many others. But far transcending all others, and worth more than all put together, is the Crimson Rambler.

Some winters I have had twenty other kinds of roses killed to the ground, and this would be unharmed. I presume that in our extreme north it would be well to take them down and cover in the fall. Is a bloomer there is nothing like it, unless it be the multiflora.

Every stem and twig seems ambitious to do all it can. It is no uncommon thing to find thousands of flowers on a single bush. Though they have no fragrance, they make it up in the wild, rollicking prodigality of bloom. Other kinds have borrowed the name 
of this rose to float into popular favor. The White Rambler and the Golden Rambler have been sold by the thousand. With us they are utterly worthless, killing to the ground in winter, and if with care you nurse them over till spring they are very shy bloomers, and they have been consigned to the brush pile in disgust as frauds.

The summer roses bloom in June and July. The best of all is Harrison's yellow, which originated years ago in Maryland. It is extremely hardy, an early and prolific bloomer, and I have never known it to be injured by any degree of heat or cold. It would probably be hardy anywhere. The moss roses are very popular. They are not quite as hardy.

Then we have Madam Plantier, which is white, and a very prolific bloomer. In fact, there is quite a fanily of these June roses, which are hardier as a general thing than the perpetuals.

THE IIYBRID OR PERPETUALS.

These have been extensively planted in the West, and people have been sorely disappointed with them, and why? Tn the East and in England they have a milder climate. When the hot winds are raging, scorching everything they touch, roses camot bloom. I have seen at Rochester, N. Y., in Angust, great fields of roses in full bloom, where the same kinds planted in Nebraska some dry seasons would not show a single flower. If, however, the fall is moist there will be a good many blooms. I will name a few of the most 


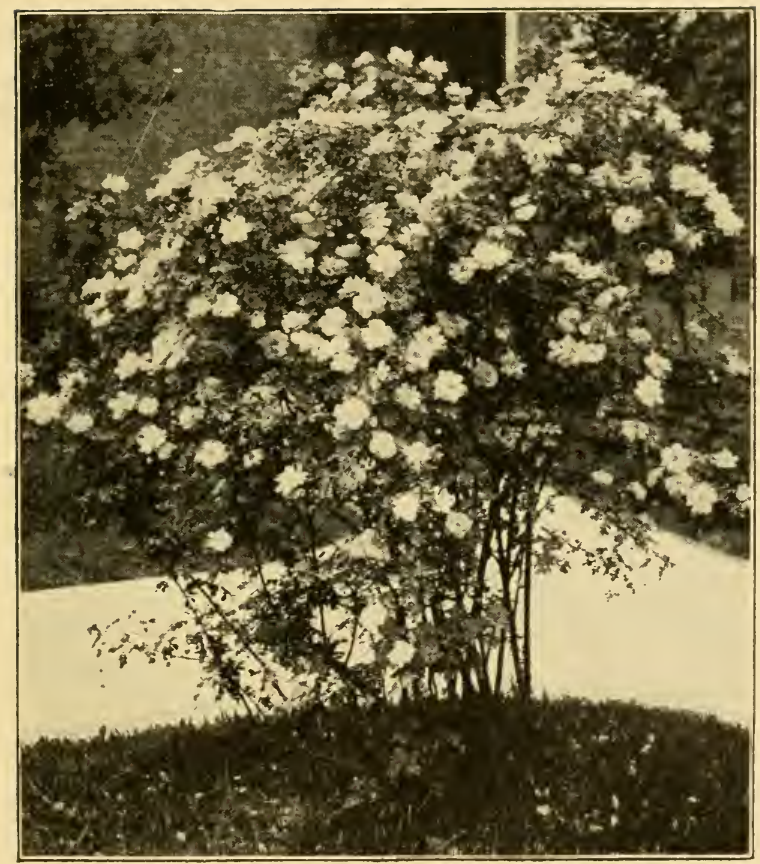

HARrison's Yellow Rose. 

popular sorts of the perpetuals, as I have seen them in the Boston flower shows, and also in the West:

American Beauty is of a large, globular, deep pink form. It is especially adapted to the greenhouse, and there are probably more of this kind raised under glass than any other.

Baroness Rothschild is light pink, very symmetrical, very distinct, with a character of its own, but, unfortunately, with little or no fragrace.

Gen'l Jacqueminot, abbreviated to Gen'l Jack. This is one of the standard sorts, and very popular. It is brilliant crimson, large and fine. It also forces well in the greenhouse.

Mabel Morrison. This is white, with a blush tint, which makes it exceedingly beantiful.

Margaret Dickson is of fine form, white, with pale flesh center, very fragrant, and fine every way.

Marshall $P$. Wilder is another favorite. It is a seedling from Gen'l Jack. It is vigorous in growth, flowers large and hemispherical in form; color, cherry carmine.

Paul Neyron. This is probably the best of the hybrids. It is the largest of all. The flowers are immense, and of deep rose color. The wood is nearly free from thorrs, and it is the hardiest of all the perpetual family.

Ulrich Bruner is brilliant cherry red, flowers of fine form. It is very vigorous and hardy for its class.

Vick's Caprice is a striking sport. It is large, pink, striped with white and carmine. 
PREPARING ROSES FOR IVINTER.

This is an important item in rose culture, for, if left to themselves in the bleak Northwest they would soon die. There are four systems of winter protection:

First. Put a headless barrel around your bushes and fill it with leaves. If too tall, cut back. Take your climbers down and cover those with leaves or straw, or, better yet, with earth; or wrap with straw and burlap.

Second. Many lay them down, putting on a sod to hold them in place, and then cover with leaves, straw, sods or earth, to be taken up in the spring.

Third. Cut all your hybrids down to the ground and burn up the brush. Then throw heavy mulching or earth over the stubs, and take it off in the spring. Gardener Hadkinson had five acres of roses under his care at the St. Louis exposition. He pushed them the first year, and they made a remarkable growth. His idea was to develop a strong root system. In the fall he cut them all to the ground without mercy, and mulched the stubs. In the spring this was removed and those strong roots were ready for business, and you might have seen the finest rose display on earth.

This system remores the slugs and insects which might be lurking in the bushes, and every spring you get a new and clean start. Roses always form on new wood, and not on the old. If you have the bushes standing you will note that they must throw out new branches before they can bloom.

Fourth. This system is my own, discorered in the 
following manner: Along in the S0's I was connected with Franklin Academy, in western Nebraska, lying under the 100th meridian. This was a difficult place in which to raise choice flowers. I had a quantity of Madam Plantier, which are white roses. They suffered much, and killed back with the winter drouth, and then by no device could I propagate them. They would not root from layers. Again, they would bloom about two weeks before commencement, to the disappointment of the girls, who wanted white roses and plenty of them for that day. So I put all these things together and sought a solution of the difficulty, and found it. In the fall the bushes had made a splendid growth. I must save them from winter killing. I wanted to propagate them, and also retard their blooming for two weeks. I laid the bushes on the gromnd like the spokes of a wheel, and put posts on them to hold them in place. The soil was rich and mellow. I put on six inches over the whole and did not allow a single bud or twig to show itself. The earth was not taken off in the spring. There lay the twigs uninjured by winter. I watched that not a branch or burl should be exposed. They were compelled to come up through the 'ground, and they did, great masses of them. Of course those twigs were perfectly healthy and the bloom was retarded two weeks, and the young ladies were delighted with having all the large fragrant white roses they needed for commencement. That was not all, when cold weather came and the leares fell I dug up the plants and found twenty well rooted bushes where I 
had one before. Instinctively the twigs as they came through the earth put out roots.

This system is the best of all. Only it takes room, and you must have just the right kind of soil. But try it as you will "eternal vigilance" will be the price of roses in the Northwest. You cannot depend on fall blooming, and so paeonies are far preferable. Usually they are longer in bloom if you plant for a succession, and they give you no trouble. 


\section{CHAPTER XIII.}

\section{THE LONICERA, OR HONEYSUCKLE.}

These, which comprise the upright and climbing varieties, were named from a noted German botanist, Lonicer. They are a very numerous family, with a wide variety of form, foliage and bloom. In the main they are extremely hardy and will thrive most anywhere, and they are quite a success all over the North.

THE BUSH OR TREE HONEYSUTKLES.

There is quite a family of the Tartarian group.

The golden berried makes a fine symmetrical bush. The flowers are fragrant, and when it is covered with golden berries it is quite attractive.

Grandiflora has very large pink flowers, which appear in May. It is vigorous and compact in growth, something of the Lombardy poplar shape. It is one of our best.

The red berried belongs to the same group and has been planted more than any other.

The Ruprechtiana is from Manchuria. This is more bush-like than the Tartarians. It is a bountiful bloomer, and is overwhelmed with a profusion of red berries in July.

The Philomelae has rosy pink flowers which appear 
in pairs in each leaf axil. It blossoms about the last of April.

Orientalis was sent out by Thos. Meehan \& Sons, of Germantown, Pa. This has pink flowers, and is worthy of a place in the collection.

The Chinensis is much like the above, being a very vigorous and hardy shrub.

The Marrowii. This is very popular in the East. It is of a broad spreading habit, and is nsed largely on railroad embankments and hillsides to cover rocks, and for this purpose is quite effective. It has lightcolored flowers and a profusion of amber fruit. It is very hardy.

Siberica has pinkish white flowers, which appear in pairs. In form it is much like the Tartarian group.

Alberti has violet, bell-shaped flowers. It is very hardy, and of creeping habit, and is a sort of a cross between the bush and climbing families.

Fragrantissima. This is from China. It retains its leaves nearly all winter, and might be classed among evergreen shrubs. The flower's are very sweet scented, and continue in bloom a long time. This is the only one I have found that was not quite hardy. In fact, I have not yet found an evergreen shrub hardy in central or western Nebraska, on account of the winter drouth, which seems to burn the foliage. Many plants will endure any degree of cold which cannot survive the winters of this section.

Standishi much resembles the above, but is rather more dense. It has ripe red berries in June. 


\section{PLANTING A GROUP.}

For mound effect, where you have room, put the Tartarian Grandiflora in the center. Then the red berried. Then the golden berried, which is not quite as vigorous. Then form circles of those of more bushy labit, like Ruprechtiana and Morrowi, and you have quite a contrast in form and in the shape of the leaves, quite a succession of bloom, and a rich variety in the size and coloring of the fruit.

\section{PROPAGATION.}

I once visited the grounds of W. B. Whittier, a nurseryman of progressive stamp, at South Framingham, Mass. There I saw a very remarkable honeysuckle. It was simply glistening with immense masses of red berries, and seemed fairly staggering under its burden.

"Мrr. Whitticr, where did you get that?"

"I raised it from seed."

It was a notable hybrid-a sort of a combination of the excellencies of them all focused in that one plant by the enterprising bees, which are onr most efficient aids in generating new varieties.

So it turns out that the Loniceras have three modes of propagation :

First-From seeds. Wash off the pulp and plant. the seed, which will probably come up the next spring. Second-By off-shoot. In a short time heavy stool: are formed, like currants or lilacs. Dig them up and tear them apart and plant. 
Third-By cuttings. Late in the fall or very early in the spring. Plant as you would cottonwood or willow cuttings. If you wait till spring you must be quick about it, for they are among the first things to start.

\section{CLIMBING HONEYSUCKLES.}

The Belgica. This is about as popular as any. It blooms from May till December. Always at it, and never tired. It has bright red fragrant flowers. It is quite hardy.

The Halleana is from Japan. It is quite a thrifty vine. The leaves of bright green hang on till December. Flowers are pure white, changing to a yellow tinge. They are very fragrant, scenting all the air. Where you have them in profusion, as when they cover an arbor, in the still twilight of a summer evening they seem to load all the air with a delicate fragrance.

The Chinese Fragrant. This is a vigorous grower, having a profusion of flowers in spring time, very useful when you wish to cover a trellis or shelter a porch.

Canadensis. This grows wild in many of the forests of the interior. It is a very robust, hardy and thrifty grower, with white on the under side of the leaves, and large yellow flowers.

Common Woodbine is a strong native, with showy flowers, red outside and buff within.

Japan Golden Leafed is quite showy in foliage. It does well in the eastern states, and perhaps would do well in the West if it could be sheltered from the hot 
sun which, with our dry air, is so fatal to many things with delicate foliage.

Tariegated Euonymous is exceedingly beautiful in the East. Its foliage is a flower of itself, but it cannot be made to live in the West. This is a creeper, and would be very desirable if we could make it live. But even under a screen it refuses to grow.

\section{OTHER CLIMIBERS.}

In eastern catalogues you will find glowing descriptions of Actinidia Arguta, a strong growing Japanese vine. Let it alone. It is worthless in the West. I tried 100 under screen and in the open. They all killed down to the ground till in disgust I hunted out and dug up the last worthless root. Let your experiment stations and nurserymen test these things. You cannot afford it.

The Japanese Ivy is very popular East. In Boston it creeps up the sides of and covers buildings of stone and brick. It succeeds in some favored locations in the West, but we cannot recommend it for general planting for the Northwest.

Quinquefoila or five-leafed ivy, often called Virginia creeper, grows wild almost everywhere, and is rery hardy. You can get it in the woods or of your nurseryman. If you want something coarse, vigorous and hardy to hide some old building, or to climb a dead tree, or cover an arbor, you can depend on this. You can grow it from cuttings or from layers.

Dutchman's Pipe is a popular old favorite that does 
fairly well in most locations. It has large leaves and flowers like an old-fashioned pipe.

Clematis. These are very popular climbers, and are planted in immense quantities.

Erecta. This is very hardy and satisfactory. It is rare, and there are hardly enough for the demand. It is herbaceous, like the paeony, and blossoms about the same time. In fact, the two go well together, and the great groups of snowy white flowers do nicely for the background for a boquet of these charming blooms, It grows about three feet tall, and bears immense masses of white flowers. It is increased by root division and from seeds, which are borne in great profusion.

The Paniculata. This is a marvelous bloomer, and pours out its beauty in a flood of white. I have them growing beside the hardy Virginia creeper. The leaves of the latter are killed by the first hard frost, and then is the time for the Paniculata to get in its work. When most of the other flowers are gone these come on in the greatest abundance. I have cut large armfuls for church decorations and for weddings. They are very effective where you want massive wreaths or wish them to adorn large rooms for festive occasions.

The Jachmanni is one of the most beautiful, and at the same time one of the most aggravating thirigs I have ever known. Once in a while they will live and grow and cover the side of a building with a profusion of rich violet-purple flowers. But as a general thing you have to plant about a dozen to get one to live. I have had them do well and grow eight or ten feet and be 


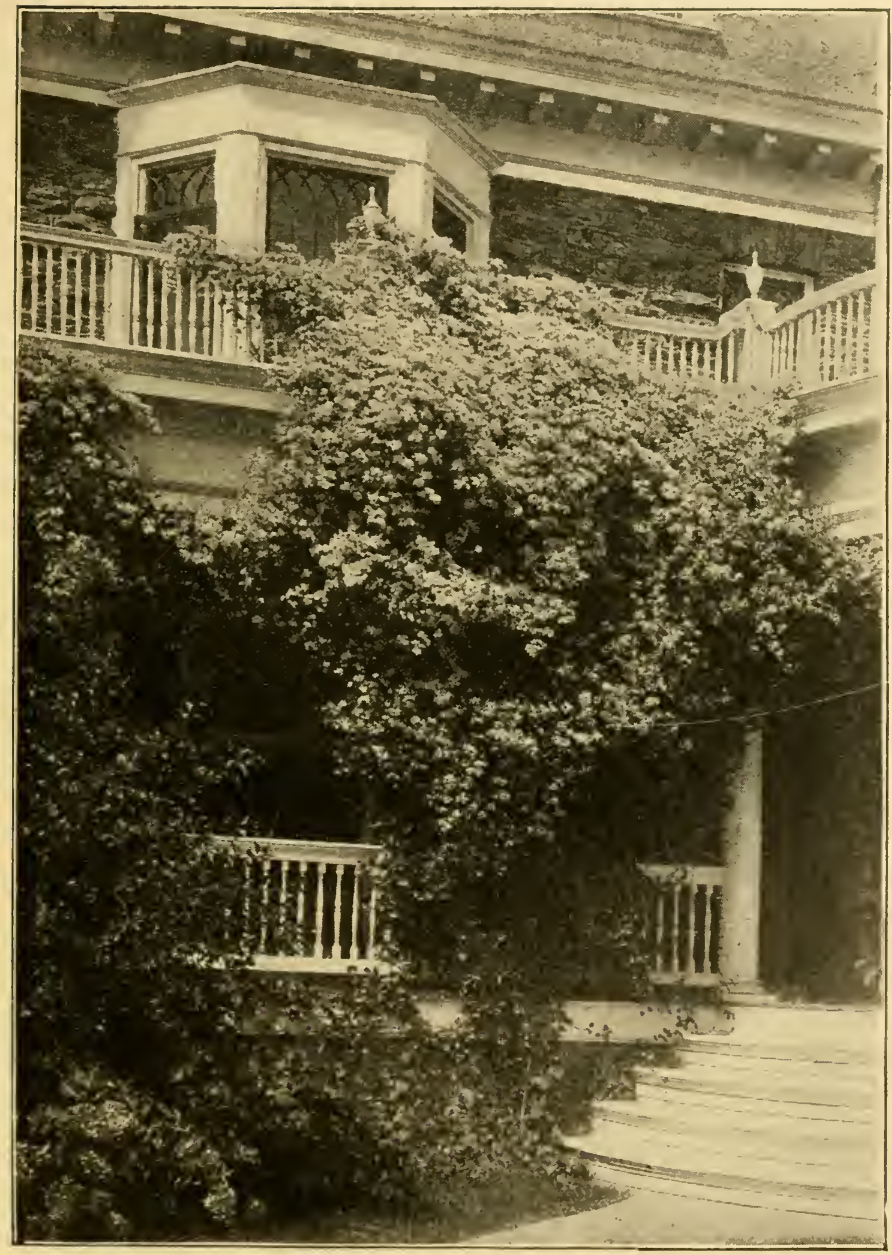

CLEMATIS PANICULATA. 

covered with bloom, and then they would take the sulks about something I never could find out and die. Yet, where they do succeed, they are all that you can ask for.

Graveolens. This is a vigorous, hardy vine. It will often spring up from seed and grow on its own account. It is a late bloomer, and has beautiful golden flowers and these are followed by great masses of feathery and fluffy clumps to which the seeds are attached. These last are about as interesting as the flowers themselves.

The Duchcss of Edinburgh has great masses of double white fiowers.

Madame Edward Andre has large flowers of beautiful bright velvety red. It is said to be a prolific and continuous bloomer.

Trumpet Flower Radicans. This is a vigorous climbing plant, generally hardy. It will kill back sometimes, however, but the root is of such vigor it will push up again. It bear's trumpet-shaped red flowers in August.

Wistarias. The American purple is a very hardy vine; in fact the hardiest of all. It is not quite as free flowering as some of the foreign sorts. There is a white variety of this vine.

The whole family was named from Wistar, once a professor in the Pennsylvania University.

The Sinensis is from China. It was introduced in 1818. It has long pendulous clusters of pale blue flowers. There is a white variety of this same species.

There are Japanese wistarias, also very beautiful, but not having tested them I cannot vouch for their hardiness. 


\section{CHAPTER XIV.}

\section{PERENNIAL FLOWERS.}

In spring the great Northwest lies at the busy end of the world. The plowing and sowing must be done. The success of the crop often depends on the seeding, which must be done early. The winters are long and when warm weather comes every moment seems crowded, and so if one is to have a fine yard it is a great help to have an abundance of choice perennials. These stay planted. You do not have to put them out every epring.

Farmers are waking up to the importance of flowers for home use. Not long ago a man asked a nursery agent what he had that would do for cut flowers. "The young folks must have them for their parties and social gatherings and they must be ordered from the city, and the team must be stopped to go to the depot after them, and they cost a good deal," and he did not see why they could not raise their own and have them fresh, and when he showed his bills, the agent said that for what he paid out in one year he could have a procession of beauty all his own and an abundance for all oceasions from early spring till frosts came. Let me name this procession. 
FIRST, TULIPS.

You plant these in October about four inches deep in well prepared soil. When the ground freezes put on some well rotted manure. Plant a lot of them; get the double rose and double white, and some mixed. You ought to have $\$ 5$ worth which would get two or three hundred. They fight their way up through slush and frosts and are the glorious harbingers of spring. You can take them up after they bloom or let them stay. Mr. Terry of Iowa 30 years ago planted tulips on a hill and had not touched them and they were blooming last year. It is perhaps as well to take them up and replant once in a while.

Next come the columbines, which begin before the tulips are through.

The pansy is the last to bloom in the fall, and begins with the tulips or before. They are easily grown. In a mild winter I have seen them bloom in the open ground in Massachusetts in January.

Before the columbines are through you have the oriental poppies and paeonies. Then the gaillardias begin, and keep at it all summer. In the meantime the irises begin their work along with the lilies. Then come the glorious phloxes and their time of blooming ean be regulated from June till October or November even.

Running parallel with your perennials your hardy flowering shrubs are in continuous bloom.

The Delphiniums and the foxgloves come on with their magnificent display. 
There are over 100 kinds of perennial asters and only a few of them have been cultivated. They get in their work after the frosts.

Many annuals come to their blooming in the middle of the summer when it is hot and dry, and they are not well enough rooted to stand the severity of the climate. Again most of the seeds of the annuals are very small and it is difficult to make them germinate. Among these, however, we must place the modern white asters which closely resemble large chrysanthemums. As they come on in August and September they are very important factors in keeping up the procession.

\section{YUCCAS.}

There are many varieties of these plants, some of them not hardy in the North. I saw some growing in Alabama that were natives there. They were six inches through and eight to ten feet tall. They are said to be very beautiful in bloom.

The two kinds in ordinary cultivation are the Rocky Mountain or Spanish bayonet and the Filamentosa. The former is by far the hardier. It grows not only in the mountains but comes down in the plains as far west as the 100th meridian. It seems to delight in dry situations, but nevertheless grows well in rich soil and responds to good cultivation. It has a long stiff leaf which is pointed by the sharpest kind of a needle. As it grows, the root lifts itself out of the ground like a large beet. This is the soap weed of the Mexicans, who often use it at the present day. The roots also, 
pounded up, are used for a hair wash, which is said to be excellent to keep it healthy and from falling out. It has a stiff spike from which pure white flowers hang like lights about a chandelier. This species I think would be hardy anywhere. They do not seem to mind any degree of heat or cold. T'hey would seed plentifully and do, when they have a chance, but the cattle which roam over the mountains and plains, though they cannot eat the tough and leathery leaves, are sure to take the flowering stem as soon as it appears.

In my trips to the mountains I often gather seeds which readily come up and the plants make rapid and vigorous growth. The leaves are compact masses of tough fiber quite useful for ropes and cords.

The Filamentosa is so named from its filaments or threads. These leaves are very tough and are used for cordage or tying, much as rafia is now used, only it is not as long or as pliable.

There are three forms of this-the common and Filamentosa Recurva. The leaves, instead of growing erect, curve downward. There is not much difference between the two, though nurserymen often make quite a distinction in faror of the curved leafed ones.

Bicolor is probably a sport of the Filamentosa Erecta. It was sent out and recommended as hardy, but it is tender and utterly worthless outside of the greenhouse.

THE FILAMENTOSA.

The Filamentosa has an immense flower stalk with branches, and in good rich ground it will grow to be 
six or seven feet tall, and when it is covered with a great mass of white blossoms like lilies, it is one of the most imposing flowers we have. Both have evergreen leaves which have a fresh color all winter.

\section{THE IRIS OR FLEUR DE LIS.}

This is "the rainbow deified." These are also called flags. There is a remarkable family here, varying from the little blue dwarf beside the walk, that blooms with the tulips, to the majestic and imposing Kæmpferi from Japan. These last have flowers of immense size and imposing beauty. Unfortunately I have never succeeded in raising them in Nebraska. I am now testing some under screen. They are growing finely and I have some hopes of them.

\section{THE GERMAN IRIS.}

These are hardy everywhere. I saw them flourishing in Manitoba. I think there are over 50 kinds of this family alone. These should be planted in full clumps. They multiply rapidly from the root and should be taken up every few years or they will begin to crowd each other.

\section{TIIE SPANISH IRIS.}

The Spanish Iris is quite hardy and beautiful. But I think one of the finest we have of recent introduction is the Siberian. I note that it is hardy everywhere. The leaves are narrow and long, the flower stalk is tall and slender and is surmounted by flowers of the most 
intense blue. I am highly pleased with it, and saw it growing at Brandon, Manitoba, so you can depend on it anywhere. There is another branch of the family with snowy white flowers which are exceedingly beautiful. These I am sure will give satisfaction.

The Digitalis or Foxglove should not be omitted. They have long flower stems, blossoms are purple and white. The grandiflora has yellow blossoms.

The Dicentra or Bleeding Heart is a very hardy plant with a profusion of heart shaped flowers in the spring. They are beautiful in the morning when, in full bloom, the sun shines on them.

The Exima is everblooming, while the first mentioned bloom early and then the foliage becomes dingy; the latter keeps fresh, growing and blooming all summer. It is very hardy and as it multiplies from the root rapidly one root would soon give an abundance. You take up both kinds either in the spring or fall and divide and replant as you would paeonies.

\section{THE RUDBECKIA OR GOLDEN GLOW.}

This is a native of North Carolina, but is hardy everywhere. Care must be taken to keep it in bounds or it becomes a weed. The clumps should not be allowed to become too large for then the flowers will be small. The tall stems need some support. These should be set in the background of the border. They are too large for the front.

The Campanula or Bluebells should not be forgotten. 
The hardy pompon chrysanthemums should not be left out. There are now about 100 kinds of these. They are very effective when you most need them. They are in their full glory about the time of the first frosts and continue to bloom like hardy asters some time after, or until the killing frosts come.

\section{COREOPSIS LANCEOLATA.}

This is very hardy and takes good care of itself with but little attention after it is once established. It has beautiful double white flowers, small but fine.

\section{COREOPSIS GRANDIFLORA.}

has golden yellow flowers on long stems.

THE SUNFLOWER.

This is an annual, but it has been so improved that we would hardly know it. The latest is an immense head and instead of a rim of yellow around the outer edges the face is one grand full glorious flower. This can be used in the background along with castor beans. 


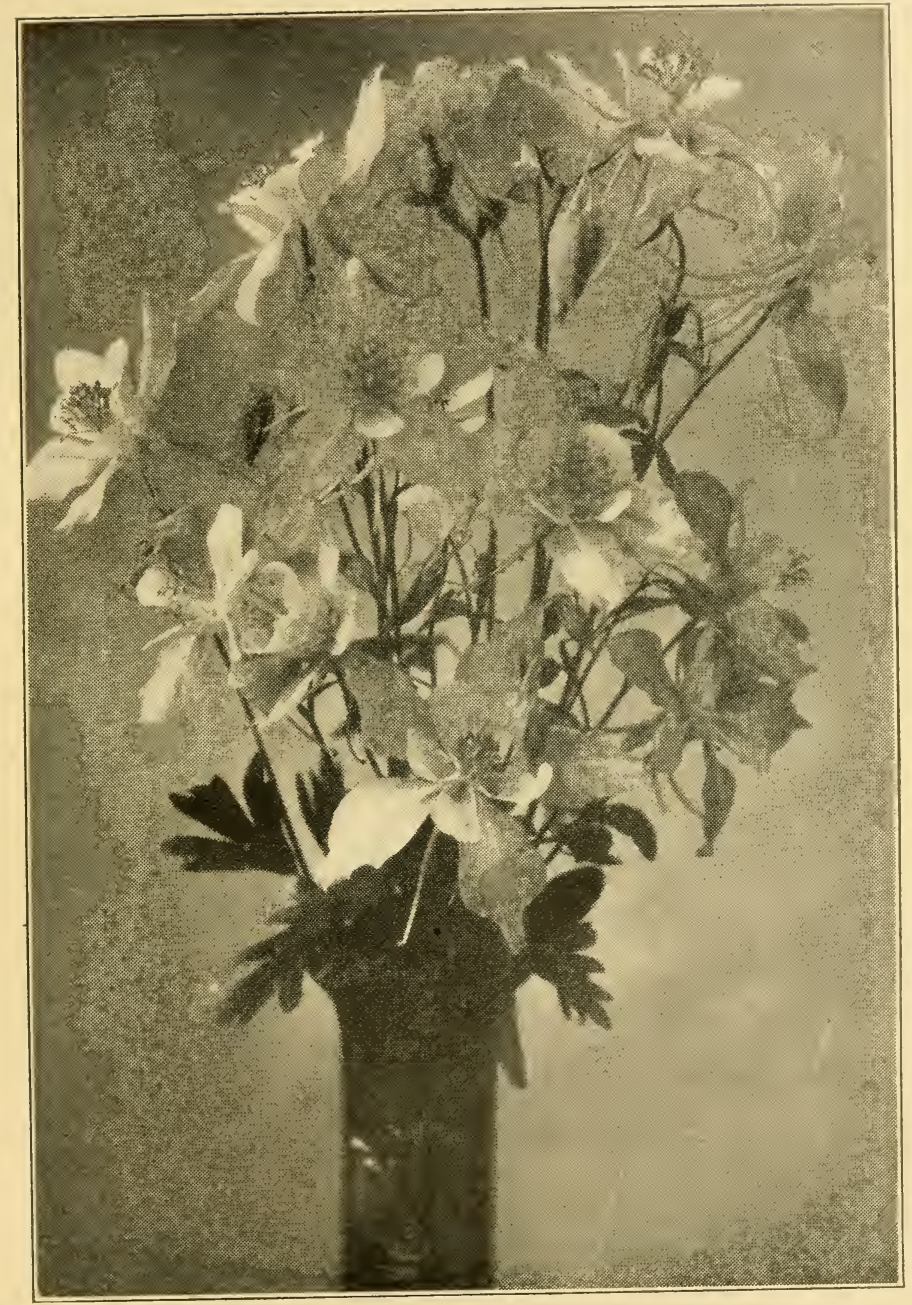

The Coerelia, or Rocky Mountain Columbine, the State Flower OF COLORADO. 



\section{CHAPTER XV.}

\section{COLUMBINES.}

It is strange that such attractive and hardy flowers, so radiantly beautiful, should receive so little attention. They are easily grown, require but little effort, and repay all care and labor needed a hundred fold. Light itself has been dissolved, and all its prismatic rays have been woven into their bloom. I think one trouble has been they have not been planted on a scale large enough and in generous masses, so that - their charms could be seen to advantage. People persist in getting a lonely flower and giving it the task of enlivening dreary surroundings, and the poor thing cannot show to advantage. Then no single one, beautiful as it may be, can represent them all.

Before my window as I write there is a large bed of them. Does one realize what a great family they are, over fifty native species? I have at least as many sorts. No flowers hybridize more readily. You secure a large variety, and then sow seeds from these, and you have a marvelous permutation of beauty. No two flowers of this second cropi will be entirely alike. The bumble bees especially delight in their' nectar. They seem almost intoxicated as they revel in it. Of course they carry the pollen from one flower to 
another, and the result is something new. There is an intense fascination in watching the various changes wrougint, and to see the bewitching loveliness of some of the new arrivals. If one could sort out some of these and name and describe them, he could give some rare treasures to the floral world. By this process you would have the pleasure of forming new acquaintances whom no one else has yet met.

Let us take a look at some of these before us. That tall one, so striking in appearance, is the Chrysantha, the golden. The color is yellow, and not only that, there is a good deal of it. It is intense, as though the flower had secured all it could and had packed and pressed it together in the most lovely form imaginable. What long and delicate spurs it has! We saw it growing wild in the Yellowstone National Park. There it was small and comparatively insignificant; but transported to our rich prairie soil, with good cultivation, it gives grateful response to our kindly attention. A flower does not blush as well unseen, while it "wastes its fragrance on the desert air," as when there are admirers to appreciate its beauty. Many a flower, comparatively unattractive in its wild state, will bloom in a prodigality of loveliness under the influence of cultivation, and where it can be seen and enjoyed. The Picea Punges, the king of beauty among the conifers, nowhere in all the mountains does as well as when transplanted in the rich soil of the prairie, or the eastern states, and receives the attention it deserves. Then the 
needles are longer and the sheen is far brighter and more radiant than in its own habitat.

Here is another of attractive appearance, with long and delicate spurs. The petals are snowy white and intense blue. It seems a photograph of the sapphire of the sky and the fleecy clouds. This is the Coerelia of the Rockies, and the state flower of Colorado. We often see these in masses at an altitude of eight or nine thousand feet. In many places they grow to great size, as some localities seem better adapted to their development than others. When taken down to the plains they need some shelter from the burning sun and hot winds. This variety readily hybridizes with others, and its motherhood is seen in many types in recent years. So readily does it cross that though the original plants will be all right, yet the progeny varies so readily and to such an extent that pure seed must be secured from the mountains if you would be sure. I keep a remote nook in the further corner of the nursery, as far removed as possible from the other's, for their exclusive use; and even here there is some danger that the bees may find them, and I cannot be absolutely sure of all those grown from them, so I make it a practice to secure fresh seed every year or two.

There is one of deepest, darkest blue, so much so it is almost black. It is a large, solid flower. It has no spurs whatever. It is quilled like the Dahlia. Another is salmon pink lined with white, a gorgeous flower, and the blooms hang like lamps in a chandelier around the parent stem. Here is one that is a large, compact, 
snowy white. It is a full and prodigal bloomer, and near it is a single white, well spurred. In close proximity is one of deep blue, a single flower, with long, slender spurs, much like the Coerelia, to which it probably owes its parentage. In the crossing it doubtless got enough of the blue from one of those of deep azure to eliminate the white.

Yonder is a double maroon on a strong stem, and its color blends well with the garments of its neighbors. Here is a large, double pink of curious form, shaped like a tiny barrel. One is lilac color and semi-double. In short in color there are samples of almost all the shades known to us. There is a tall, independent one, a sort of a blend of blue and maroon, lilac and rose color, showing that the pollen of several different ones had entered into combination to form one so fresh and rare.

Time would fail to describe them all. The Golden is less liable than others to enter into crosses. One reason is that it is so much later, and yet there are several that show its influence, and many of the golden ones have been somewhat swerved from their distinct form. These flowers commence blooming with the Tulips, and continue to flower for two months, while the Chrysantha will break out now and then all summer. Imagine if you can a blend of these charming colors in a mass of several hundred, some early, others late, some single and many double, many of them tall and others dwarfs. In color from purest white to deepest purple. 
There is a Columbine Society at Boston, hard at work to have these adopted as the national flower. They are Aquilegia, related to our bird of freedom. They are Columbines, which sounds something like our own Columbia. Then we have quite a number of native varieties. So the society is making a strong plea. Many designs in decorations are taken from these flowers. And as one of the states has adopted one of the family as its own flower, this may be the beginning, and perhaps ultimately the Union may follow one of our richest states.

HOW TO GROW THEM.

Get a quantity of mixed seed and sow early in the spring. The seeds are small, and of course must be planted shallow. But here is the trouble, especially in -the west-the ground dries before the seed can germinate. Contrive some way to keep the surface wet all the while, day and night, till they come up. But you would better trust to experts, who make it their business, and buy the plants, which can be had at very reasonable rates, three to ten dollars a hundred, and thus save a good deal of care and rexation and a year's growth, as they will bloom some the first season. Put in rows eighteen to twenty-four inches apart, and twelve to eighteen inches in the row, and they will soon stool out and cover the ground. It is best to mulch well with coarse manure after the ground freezes, and in the spring rake it between the rows. I do not always take this trouble, for they are very hardy. If the season 
is wet, some of the seeds, as they fall, may grow, and thus extend the area. The seeds have great vitality. Some sow them in the fall. Columbines are used a good deal for cut flowers, though they are not as good keepers as Paeonies. They are in season on the nation's great flower day, when we decorate the graves of our dead. Some late springs they are about the only outdoor flower we can use, as was the case in 1904, when they were in the full glory of their bloom in great massies.

So plant Columbines. There should be a flower procession from the opening of the Tulips to the hard frosts of autumn, and these should have a prominent place. The more you have of them the more you will admire them, and when you get well acquainted with them you could not get along without them.

\section{DELPHINIUMS.}

In our search for hardy perennials we have found this among the most showy and beautiful. If you travel in the Rockies you will meet these flowers in all their glory. In the rich valleys you often see them six or seven feet high, and the tall, strong stem lined with a covering of flowers of deepest blue.

This flower, sometimes called the Larkspur, has been much improved. In the Boston flower shows I have seen gorgeous specimens of grand, radiant flowers which seemed at great remove from our native plants. These tall ones are clothed with the splendor of sapphire, and so intense is the color it would scem as though all the 
shadings and tinting which could be extracted were there in a narrelous blending. I have some very rich specimens, which draw the attention of visitors. They are about six feet tall. Some are like great posts frescoed with bloom; others are branching, and all are grand. They follow hard after the Paeonies, and bridge the chasm between them and the Phloxes.

Over in England they have made great improvements in these flowers. By careful selection and hybridizing they have secured a race far superior to our native sorts: but though these choice strains may do well in the milder climate of that country, they do not winter well with us. But we have such a rich variety there is no reason why we also cannot improve, and thus secure hardiness with beauty.

I give the following as an English tribute to this flower:

Delphiniums-As permanent subjects in the hardy flower garden we have few plants more worthy of special attention than the Delphiniums. For producing a striking display over a long season they are probably unique. For general effect in groups or beds they are extremely valuable as a whole, but one is easily carried away on closer inspection by the exquisite beauty of their flowers, particularly those with clear, sky-blue shades. Indeed, they have many points of excellence, any one of which alone should entitle them to popularity. But to appreciate their beauty one must see them growing, for it is almost impossible to convey anything like an adequate idea of their worth by mere 
description, and it is equally impossible to place their towering and densely-flowered spikes before the public at the summer exhibitions in a manner worthy of them. Those who have not the opportunity of seeing these plants in flower, or a collection of them well established, may form some idea of a group with the flower spikes five to eight feet high, and densely clothed for about half their length with exquisitely beautiful blooms. Of course the plants do not reach such perfection in the first year, but in the second year they certainly constitute the grandest possible display. While making the garden gay for a long season, they are in the greatest perfection in June and July, but a judicious selection of them may somewhat extend that period. Where seed is not required the plants should be cut down as soon as flowering is over, and in the late summer months many of them will yield another set of spikes, not so fine, of course, as the first ones. The shades of blue, both light and dark, are very numerous; others, again, have flowers of the deepest indigo and violet, while less numerous are those with bronzy and metallic hues combined with other shades.-Gardening Illustrated.

I here give place for an excellent article from E. Hemming, in Florists' Exchange of July 9, 1904 :

Among hardy perennials the Delphinium, or Perennial Larkspur, has held front place for the past two weeks. Closely following the late varieties of Paeonies, they stand out as the most showy border plants blooming at the present time. A good, large collection of these plants is a sight to be remembered, especially 
when well grown and cared for. The exquisite shades of blue have to be seen to be appreciated. While the named kinds girown so extensively in England soon die out and require great eare to perpetuate them in this country, they are so easily grown from seed, and so invariably give good results if a good strain of seed is procured, that they should be better known among florists. A visit among the gardens along the Hudson revealed the fact that they grow exceptionally well in that locality; and spikes towering up to eight and nine feet high were not at all uncommon.

Delphinium Elatum, or Exalatum, is a native of North America. This is supposed to be the origin of the tall garden varieties, often called English Delphiniumns, that have been so much improved by Kelway and other nurserymen.

Delphinium Formosum is of more branching habit, seldom exceeding the height of three feet, but a prime favorite, owing to its beautiful color, which is a combination of indigo, violet and sky blue.

D. Grandiflorum, or Chinensis, as it is often called, is a very fine cut-leafed kind, having several varieties.

All the above are good, and well worth growing, being uscful for cutting and attractive in every way, and the same treatment will suit them all.

Of course it is neeessary to propagate named kinds by division or cuttings. This should be done in the very early spring. Growing them from seed, however, is the most satisfactory way. D. Formosum and D. Grandiflorum come fairly true from seed, producing 
very few poor forms if the seed is procured from a reliable source. The seed should be fresh, as it seems to lose its germinating power very rapidly. Sown in early spring, it will produce plants that will flower the first year. Of course the flower spikes are not very large, but sufficiently so to select the best to plant out in the position they are wanted to fill. When in a young state care should be taken to keep a sharp lookout for snails, as these pests seem passionately fond of the plants, and will make sad havoe of them in a short time.

Quite a percentage of Kelway's hybrids will come double from seed, but it is an open question if the double forms are superior to the single ones.

As regards the after treatment, or when they are planted in the open ground, deep, generous cultivation and good, rich soil is what they like; and, when planting, see that the crowns are well below the surface of the soil; one and a half to two inches is not too much. As soon as the plants have done flowering, unless they are wanted for seed, the flower stems should be cut down. This will induce a second crop of flowers. While perhaps not equal to the first crop, they will be found to be well worth looking after.

The seeds of this plant are quite small, and it is very difficult to germinate them, as the ground dries up while they are sprouting. It is perhaps as well to get the plants in the spring and give them the best of care. They will bloom in good season.

Intense blue among flowers is a striking color, and is needed to cover the range of beauty. Many of our 
choicest families, like the Paeony and Rose, aroid that color altogether. But when you see the Delphinium in all its glory, with those rich tints, and all the delicate penciling and tracing done with nature's most skillful touch, you will feel that you have the link you need in the chain of beauty.

I was delighted in a trip to the extreme north to find these glorions flowers in their perfection. They were in evidence in the parks of Wimnipeg, and in many private grounds. It was encouraging to see them like posts, six feet high, eovered in their robes of blue. Their extreme hardiness is a matter of great encouragement. In the border, set them back near the shrubbery, for they are too rank to place them near the walk.

When you can have such imposing flowers as these, you need not wait long to surround your home with as inuch beauty as can be found anywhere.

\section{THE LILY.}

There are about fifty species of this glorious flower, ranging in size from the attractive little Tenuifolium to the immene Giganteum, which must have five years to complete bulb, which throws up a stem six inches through and ten feet high.

There is also a wide range in the time of flowering, which covers a good portion of the summer. It is not practical to secure the whole of this family, but enough of the leading kinds can be planted to have a cheering variety. 
One trouble has been in understanding them-their nature and needs. Siberian lilies are covered deep with snow in winter, so are those of the Rockies, and the natives of Minnesota and the North. There are fine ones growing in the woods of Canada. All these are carefully covered up with the snow mantle in winter, and this is the best corering ever devised. Now, take these same plants from their own habitat and plant them on the open, bleak prairies of the West and many of them will perish. The bare ground freezes deep. They are often planted shallow, and so they die for want of protection. Many are so hardy they will endure anything.

This is true of the Hermorocallis family and some others.

Generally, the soil is not prepared thoroughly enough, and they are not planted deep enough. Some dig a trench, put manure in the bottom, then some fine earth, then plant a foot deep, and cover with sand or light earth, so the plant can readily push its way up.

C. L. Allen, in a recent work, gives the following directions: "To prepare a proper home for the Iily" the soil should be thrown out to the depth of two feet. Then, in the bottom of the trench, put six inches of cow manure; then put on twelve inches of well rotted sod; on this put two inches of clean sand; then plant the bulbs and cover with fine earth. But for the western prairies this is not deep enough." From my own experience, I think a depth of eight to twelve inches is preferable. Only be careful of the kind of earth with 
which you cover them. If you put on stiff clay it will be hard for them to bore their way through. Light earth, mixed with old and thoroughly pulverized manure, should be used. In no case allow the bulbs to touch fresh manure. Then, when winter comes, put on about six inches of coarse manure. In this way you will obtain protection for your bulbs, and, though the ground may freeze, they will not be near enough to "all out of doors" to hurt them. The bulb, like that of the Paeony, carries the life and sustenance of the plant.

Cared for in the way deseribed, the lilies will retain their vigor, and all up and down the stem new bulbs will form. Never plant them on wet ground. Though they need water in a dry time, they cannot endure wet feet.

I think there is no soil better for their propagation than our rich, light, prairie loam. Here they bloom gloriously, and propagate freely.

\section{TIIE TIME TO PLANT.}

The Candidum, or Annunciation Lily, with its bloom of purest white, should be planted in its dormant condition, which is the last of August and the first of September. After a brief period of rest it begins to grow, and produces quite a tuft of foliage before winter sets in. We cannot speak too highly of this exquisitely beautiful flower. It is often used for forcing, to produce flowers for Easter. Its purity of whiteness and delightful fragranee make it a favorite. It does not seem to be a hard plant to raise. I have planted them, 
when badly grown, as late as October, and they did well, in spite of the shock of moving at the wrong time.

The Lily should not remain out of ground long before planting, and must never be allowed to dry. There is a great advantage in securing home-grown instead of imported ones, for, unless properly packed, they must suffer for being so long out of ground.

Some kinds do best with partial shade, while others flourish in the open. I have a grand one from the North Carolina mountains, sent out by Fred Kelsey. It does not do well in the open; it does not grow so tall or flower so freely as those under partial screen and good surrounding shelter. These grow to be seven feet high, with glorious clusters of freckled yellow flowers. They have a rich, soft coloring, and give them forest or native conditions, with plenty of water in a dry time, and they will be all you can ask for.

The beantiful Golden Funkai, or Day Lily, is an early one. It has a clear, yellow color. There is another, much taller and later, which is very satisfactory.

One of the hardiest, most showy, as well as attractive, is the Elegans. It blooms along with the Paeonies, and goes into the wholesale business, covering the whole plant with a mantle of bloom. These propagate readily; the stem under ground has a string of bulblets on it. Dig up the whole; plant the larger ones for next year's flowering, and the small ones for another year's growth.

Then come the double and single Tiger Lilies. These are very robust, hardy and prolific of bloom. Up and down the stem tiny bulbs are attached, about 
the size of blackberries. Do you wish to multiply them as rapidly as possible? Then eut off these stems as carefully as possible, so as not to shatter off the tiny bulblets, and plant them in good, light soil, corering about two or three inches deep. The embryo bulbs seem to feed on the stem, and in the spring they come up good and strong. It takes a couple of years or so for them to be large enough to flower.

The Pardanthus Chinensis or Leopard Flower rather belongs to the Iris family, yet it is called the Blackberry Lily. It is rather late, blossoming in mid-summer. It has a very pretty little flower, and when that is gone a blackberry takes its place, continuing the attraction of the plant. These berries hang on a long time. If you wish for more of these flowers, plant the blackberries in the spring, and they will grow readily.

The Plantain Lily grows to have very large stools of beautiful foliage. They have snowy white blossoms, very much like the Candidum. They bloom in August.

The Homerocallis are strong plants. These do not have bulbous ronts, but are propagated by root separation, and also by seeds.

The Temnifolia is the sweetest and daintiest of all. Charming blooms hang like chandeliers around the stem. These roots are edible, and the traveler in the woods of Siberia finds a plant with a charming flower at one end and a potato at the other.

Many kinds do not multiply rapidly, though the root makes it up by producing seed, which can be planted 
in the spring, care being taken not to allow them to dry during germination.

J. Wilkinson Elliot, of Pittsburg, Pa., gives this description of a garden of lilies:

"A correspondent complains that we have told him too often of the lawyer's garden; but it is still the best garden in this vicinity, and a good garden cannot be told about too often.

"Our friend, the lawyer, has a garden of Lillies. Many other things he has in his garden-great banks of M[ollis and Ghent Azaleas that are worth a long journey to see; an entire hillside is covered with hybrid Rhododendrons and Kalmia Latifolia; Tulips, Daffodils and Crocuses are everywhere in the spring, and the glorious show of Japanese Irises in June is a sight not easily to be forgotten-but he has Lilies by the hundred and by the thousand, and in so many varieties that from June until November there is always a fine display of Lily flowers. Such a garden! By daylight it is splendid, by moonlight it is fairyland, and the air is filled with fragrance. Such a garden to visit, as we do visit it, and travel forty miles a dozen times a year, and come away with our arms filled with great stalks of Lily bloom; for this is a garden in which there are always flowers to cut and to spare. It is not the miserable garden of bedding plants in which its owner finds it difficult to cut a little nosegay to give to a friend. We wish you who are content to grow such commonplace things of so little beauty as Cannas, Geraniums, Coleus and Alternantheras, could visit this garden of 


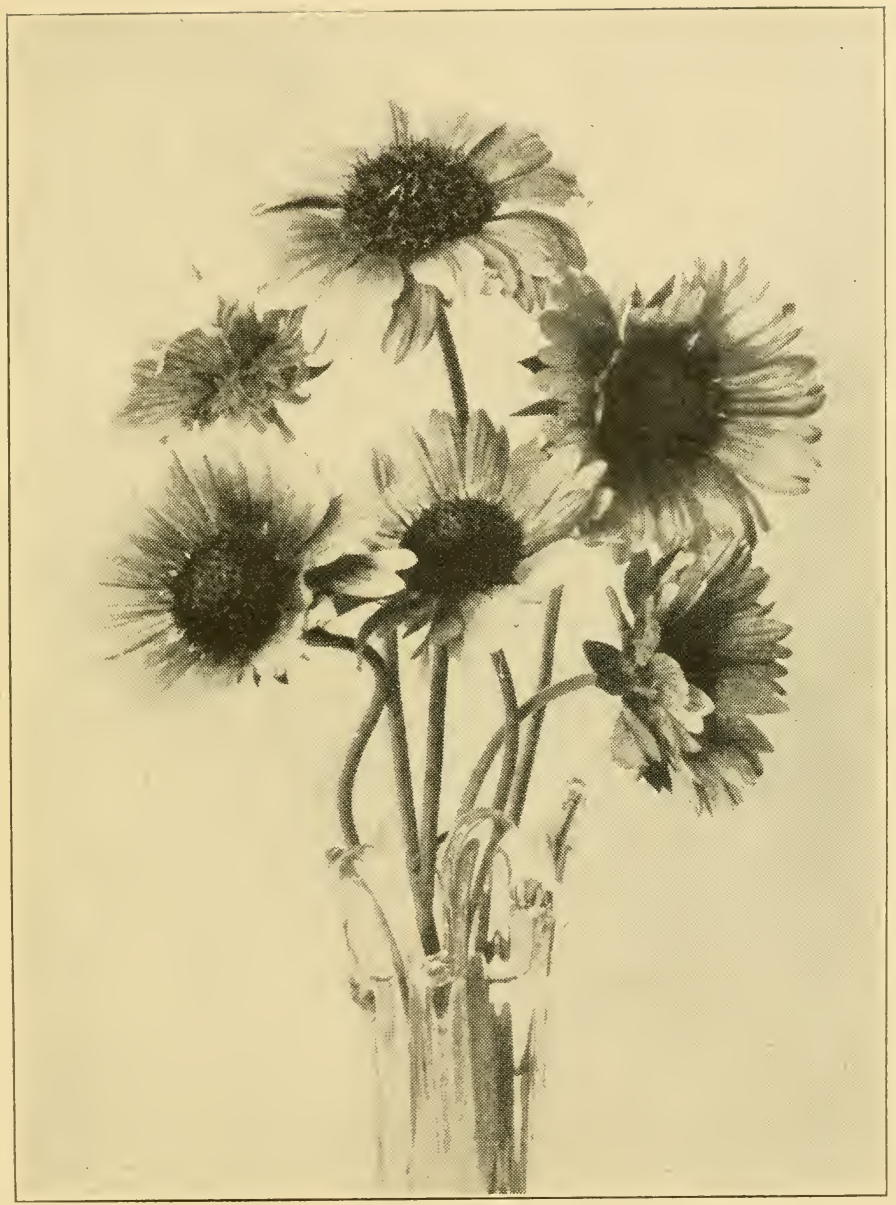

Gaillardia Grandiflora. 

Lilies, and then say what excuse you have to offer for rour poor taste. Not that of cost, for Lily bulbs are to be had for as little money as bedding plants, and as Lilies are hardy, their first cost is their only cost, while bedding plants must be bought every season."

We are to remember this was written of the east, and that Azaleas and Kalmias will not grow in the West.

\section{TIIE G.IILLIRDIA.}

This perennial is beginning to receive much attention, and with reason. There is no plant so susceptible of improvement. In England the Kelways have made marvelous suceess as regards size and color. They have prodiced some five inches across. A bed of them presents a very lively and brilliant appearance. They are prodigal bloomers. I doubt if there is any flower which can give such an abundance of continuous bloom as these. Commencing in June, they are clothed in heauty until the hard frosts of Autumn. They endure dry weather well, and seem hardy every way. As cut flowers they are brilliant and showy and among the longest keepers.

They need heary mulching with coarse manure when the ground freezes. It would be as well to leave the tops on and throw the mulching on them, thus giving ventilation as well as protection. The seeds grow readily. A portion can be started in the house and then set out after danger of frost is over. Of course it is better to get the plants, but the roots are small, compared to the upper growth, and seem insignificant. 
Seed sown in the open germinates readily, and the plants become very vigorous and commence to bloom as snon as large enough. These flowers you can depend on. Others, like Roses, Paeonies and Lilies, have their season and pass on. But the Gaillardias take all the season, and when others fail, you can count on them. Though new to most people, I find they take well when ordinary floral displays are needed.

The Grandifiora is a fine, large flower. In color it is a madrler, maroon and gold, often with other tints. Some will have very open faces and others will have petals compressed at the base and expanded in the outer rim. It is easy to see how, with such a variety of form and color, selections can be made, and they can be increased in size. The English have pushed things so far that the most highly developed ones are not hardy. I think perhaps if these gorgeous ones were crossed with our own natives, we might have some of hardier strains. Should you ever get imported ones, I would advise you to take up the roots in the fall and store in boxes of earth till spring. I had quite a quantity, and even heavy mulching did not save them.

I had for some time supposed that all Gaillardias were perennials, but I find they are not.

Lorenziana is a double with a full cushion richly variegated.

Amblydon is blood red. Sow these early in the spring and they blossom in June and keep at it all summer. 


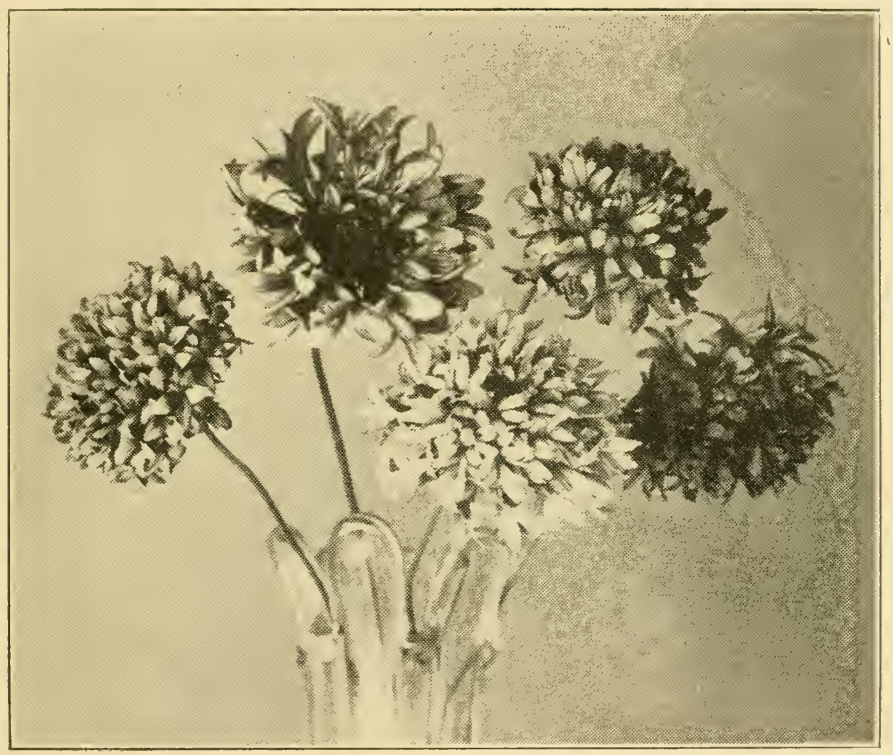

GaILlardia Lorenziana. 


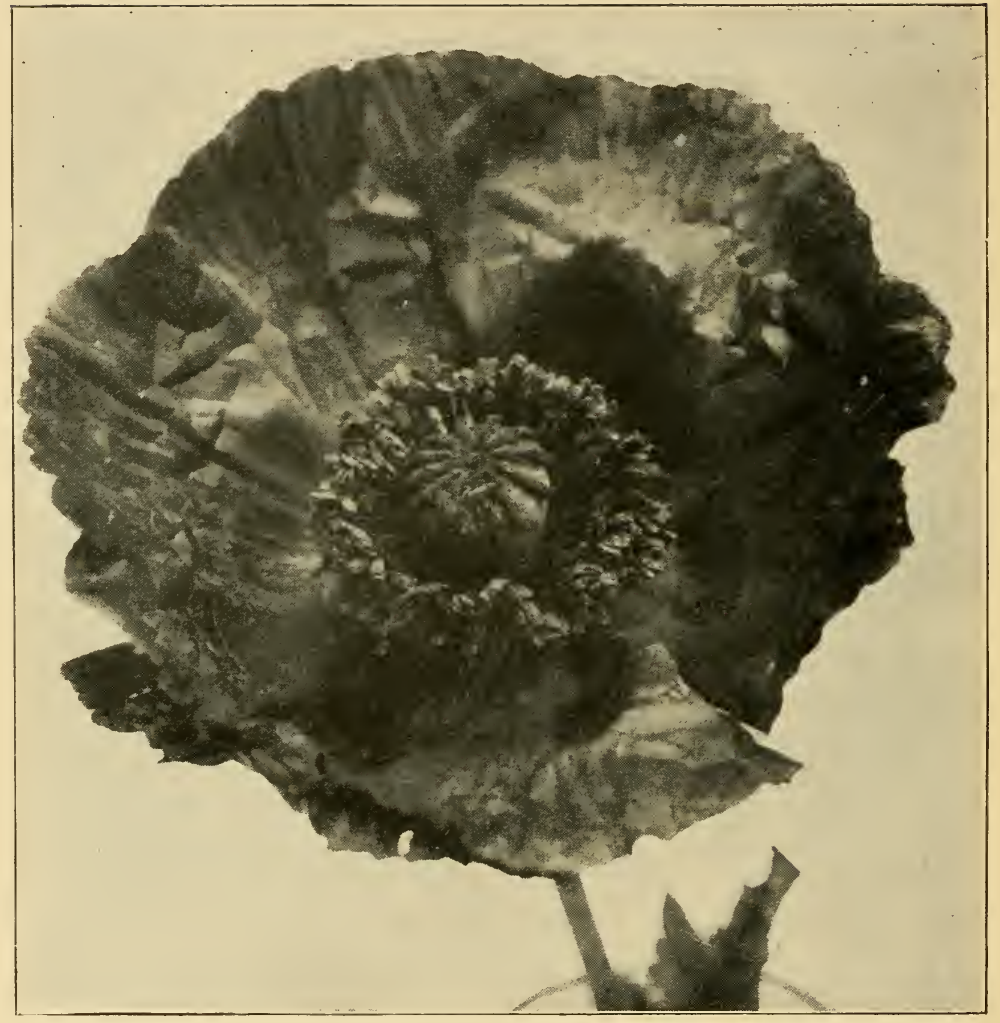

Oriental Perexnial Poppy. 
A native Gaillardia grows in Western Nebraska which flowers freely. This also secms to be an annual, blooming freely in the summer. Grandiflora is perennial.

THE ORIENTAL POPPY.

Years ago, visiting one of the eastern parks, I saw a marvelous flower. It was a very blaze of splendordazzling in its effulgence. The blossoms were of immense size, and of flame color so brilliant as to amaze you. They were often seven inches across, and within a seed pod of exquisite symmetry, and set around it were feathery and delicate stamens. The inner sides of the petals were adorned with the most remarkable tracery and peneilings, and all this inside work was done in ebony. Taken as a whole, its immense size and exquisite workmanship made it a marked flower. I had tried so many choice things from the east and found them failures in the west, I was a little afraid of this. The next year I secured some, and found to my delight that they are well adapted to all the West and Northwest. Since then I have seen them growing without winter protection in the Yellowstone Park in a garden near the Mammoth Hot Springs. They prove hardy in Minnesota, and I saw them in Manitoba, so that there is no doubt of their hardiness.

The root is in shape and color like a small parsnip. The seeds are so small it is a difficult matter to raise them. You must put them under a sereen, and put birlap over them, and water that every night till the 
plants begin to come up. Then take the eloth off at night, and water carefully with the sprinkler, care being taken to keep the screen on. I lost about 50,000 at one time by taking off the screen. The sun burnerd them up. It is as well to get the plants. They can be sent by mail. Get good one-year-old roots, and some of them will bloom the next year. The best time to plant is in the fall. If you cannot do this, plant early in the spring. A gentleman visiting our place from Illinois said that he had plants bloom twenty-five years in succession without any corering; but I think it is well to throw some coarse litter over them. After they bloom in June, the tops seem to droop and then die, and you might think the whole thing dead, root and all; but they are only going into a dormant condition for rest after producing those enormous flowers which scem to exhaust them. But about the first of September they begin to revive and send up new leaves and the roots put on new vigor for the next summer's work.

They bloom with the Paeonies. The individual flowers last but a few days; but if you have a good sized bed of them, there will be a succession of flowers for weeks.

Of recent years there has been great improvement in them. The Orientale is bright scarlet. The Bracteatum is deep crimson, and with a double set of leaves - a grand and stately flower. There are sometimes sports or variations; for instance, last summer I found one of salmon color, which I am saving with great care. Silver Queen is silver blush. Pilosum is pale 


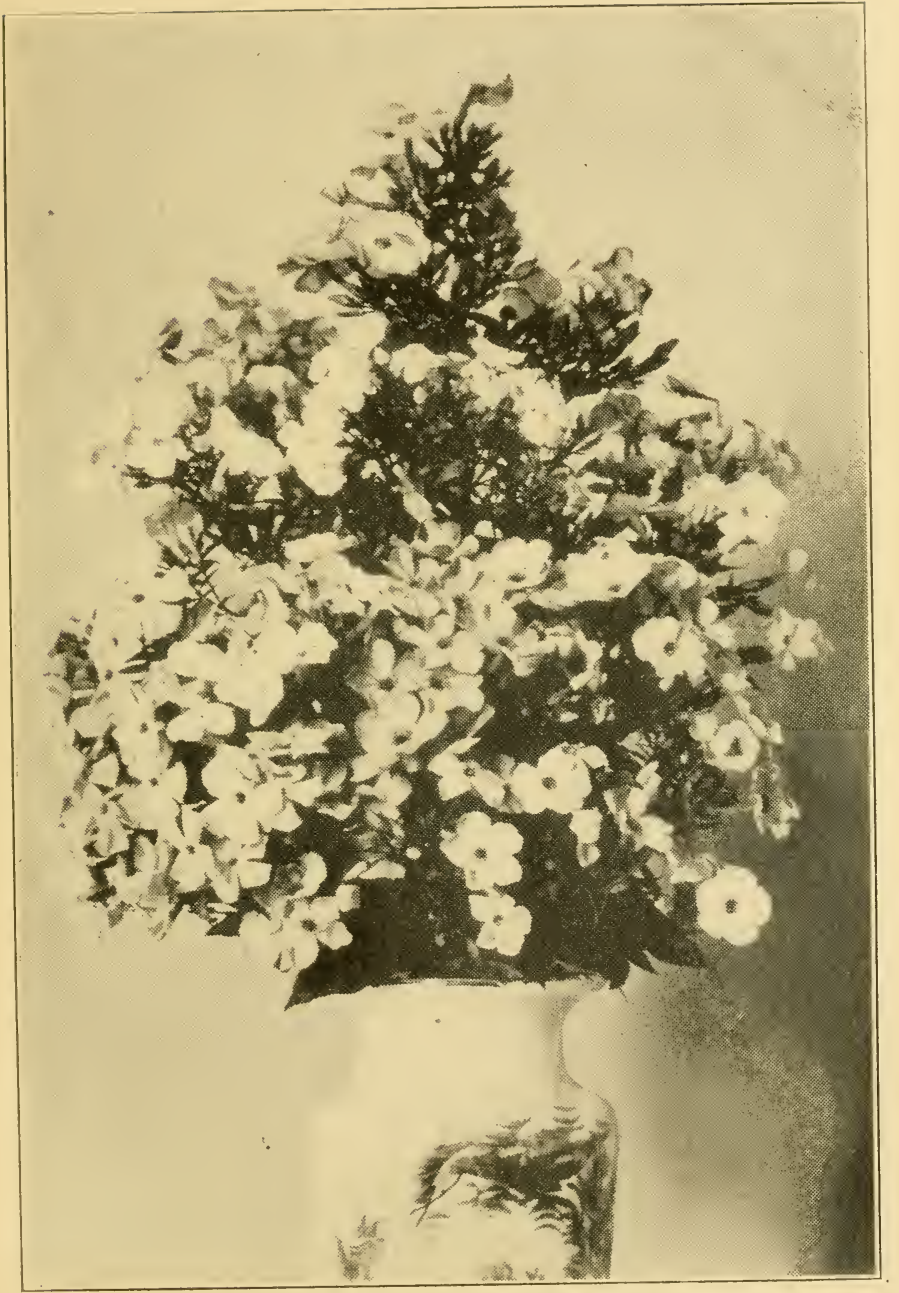

Seedling PHLoxes in York, Nebraska, in Bloom Nov. 1st, After Severat Severe Frosts. 

lurid searlet, rery showy and distinet, and of a coppery hue.

We are probably on the eve of great advance with this flower. $\Lambda$ s soon as they begin to turn from the original type, you may expect rapid and wide variations.

I have recently secured a few of the newer sorts and will soon see what can be done in the way of crossing them.

This flower is a native of Armenia.

\section{PHLOXES.}

I once gathered a lot of seed for planting and laid them in a vacant room upstairs. A few nights after, in the stillness of the night, we heard a noise much like popping coln. Going up to find out the cause, there was another sharp snapping sound, and I saw a phlox seed shoot across the room. Then I learned another lesson on the intelligence of Nature. I foumd out afterwards that in the garden the ripe seeds would snap out quite a distance from the plant. Of course the design is to extend their scope and area and gradually possess more ground. This opened my eyes to the possibilities of their improvement in raising them from seed.

This is not a diffienlt matter if you know how. If you don't, you will make a failure.

An old and careful florist who had rare success on other lines told me he never could raise phloxes from seed. I asked him what his method had been. He 
said he sent to the best florists for the very choicest seed, and he planted, it time and again and not a seed grew.

"Did you plant in the fall or spring?"

"In the spring, of course."

"Well, there is just where you missed it. If you will watch Nature, you will see that she throws the seed on the ground, where it lays subject to the heat and cold, lying in the slush and snow and freezing and thawing, and then the seeds will come up like hardy weeds in the spring. If the winter has been wet and cold with a good deal of freezing and thawing, you will see hundreds of little ones coming up all around the parent plants."

Sometimes these are hoed up for weeds, sometimes the gardener thinks they will amount to nothing; that they will be nothing but scrubs, and so he hoes them up, and thus thousands of promising little plants have been destroyed. The way is to pick the seed just before they are ready to burst from the pod; put them in a basket or large paper box with a cover on so they will not pop out. Sow them in the fall under a screen or where you can water them well in the spring. See that they do not dry when germinating, and you will have a fine bed of strong plants which will begin to bloom the first of July and continue till the hard frosts of autumn. The accompanying picture shows a group of seedlings in bloom November 1st-of course, after several frosts. 


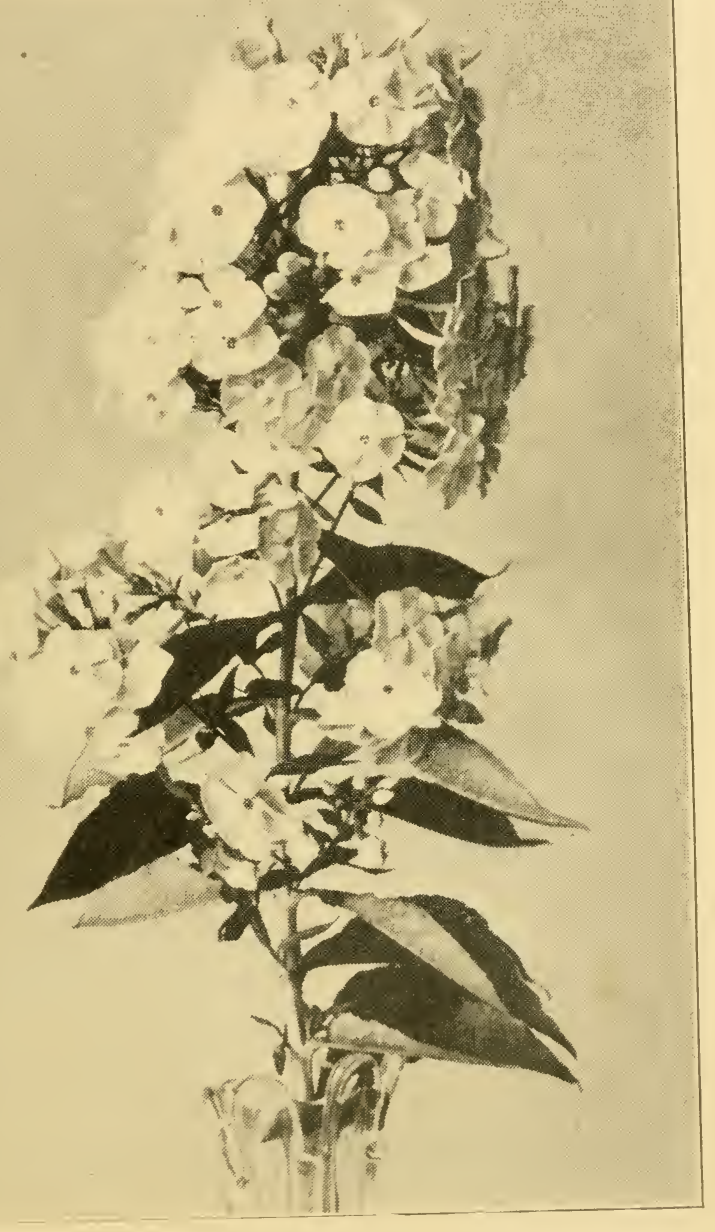

Crepuscule Phlox. 



\section{A DISCOVERT.}

It is a well known fact that some fruits and flowers have a marvelous degree of motherhood. The Concord grape, the Wealthy and Duchess apples have a numerous progeny. This is true in the floral world. For years I had been raising seedling phloxes. I found no deterioration, and often improvement. If you plant a choice kind away by itself, it will be reproduced from the seed to a large extent, and often when intermingled the progeny will surpass the parents.

Of course, it was necessary to have a mother with the choicest of characteristics. What was needed was a full head, large flowers and continuous bloom.

This was found in the Crepuscule of French origin. The flower is as large as a silver dollar. It has a com'pact, massive head, as though it was one large blossom. The bloom is white with violet shade and a large bright carmine eye. It is rather dwarf in habit, for it prefers to make bloom rather than stem or wood. Every way it is an ideal flower.

I planted this in the midst of others. Right by the side of it was the Coquelicot, also of French origin. This has blossoms of intense flame color, but unfortunately the flowers are small, and they sunburn badly. In themselves they are worthless. But Mother Crepuscule imparted both size and hardiness to the offspring of these plants. On the other side there were those that were red, some magenta and others of various colors. Seeds of these gave fine distinct flowers and 
large size. In short, as the result of that companionship I found I had at least twenty varieties, and most of them much finer than any I could import. A noted florist came to see them. Of course, it was difficult for me to keep still after my discovery. He was delighted. Taking out a silver dollar, he laid it on one of the flowers of one of my new creations. He found it. would not cover it, and then, to be exact, he said facetiously, "It would take just about one dollar and thirty-five cents to cover that single bloom." While that was the largest, there were several others which would strain a dollar to cover them. Of course, this opens a new chapter, and I ain now on the highway of other discoveries. I have sent for the largest I can hear of and intend to follow this matter up.

There is this difference between phloxes and paeonies. You plant the seed of the former, and you get your results within the year, often in ten months; whereas with the latter it will take five to eight years.

TIME OF PLANTING.

I find it is best to plant in the fall. Have your ground rich and friable-well pulverized so the plant can easily assimilate the food. If you want a plant to do its best, you must do your best by it. Always mulch in winter.

You may put the finest kind that money will buy in the sod, and give it neglect, and the flowers will be small. Then you say the florist has deceived you, when if you would go to his grounds you would find every- 
thing as he represented. Now if a plant like the phlox is to do its best work, it must have the very best chance. Put them about two feet apart each way and give them the best of cultivation, and you will have your reward. If you were fitting a lot of choice cattle for the show ring, you would not feed them on straw and treat them with utter neglect. Your great Holstein must have something besides rotten and mouldy hay if you expect a good flow of milk. So if your flowers are expected to go on dress parade, you must give them something to make their beautiful garments out of.

It is not wise to send for seeds. People often ask me for them. I refuse. It is hard to separate them from the pods. The better way is to get the plants, if only a few, and raise your own seed. You can have the time of blooming under absolute control from Jume till November. If you have a large bed, when they are six inches to a foot high, mow off a portion. This retards them, and you can vary this method to fit the time you wish them to flower. Again, you may have a bed a year old. These, if undisturbed, will bloom early. Then will come the fall planted ones, a little later in blooming. Then those planted in the spring. Lastly those grown from seed will take the remainder of the season, till the hard frosts of autumn.

It is well to take up and separate the roots every fall. Under good care they readily double every year, and some plants will give you three or four. Do not plant them in heavy clay lands, for the fibrous roots 
are very tender and will break as you separate the stiff earth from them.

THE NAME PHLOX.

The signification is flame, on account of the bri!liancy of the flowers. In the early days of Illinois, we used to see great fields of these plants in the fullness of their beauty. Along in the fifties I used to ride over the vast prairies of Minnesota, where there would be great flower gardens of thousands of acres, which filled the air with their fragrance; and the tonic of the fresh air laden with perfume, and the immense fields of grọving beauty would bring a new zest to life.

In the Yellowstone Park there is a beautiful creeping Phlox, which blooms in spite of the frosts. It spreads out in clusters, often covering the rocks. It is flesh, or light pink, in color, and a very attractive flower.

The Phlox is a native of North America. It was taken to Europe, and in the hands of florists there, it has shown variations of form and color that are amazing. Its cultivation has great possibilities for the amateur. The family is so large and the variations so extensive that hybridization is yet going on. Their improvement and development have reached that stage where, with a little care, we can have a marvelous diversity in form and color. Plant the choice varieties by themselves; save the seed, planting it under a screen in the fall, and you stand a chance of securing the same. Of course, if you raise for the market you 
should wait till they flower, and eliminate everything not up to the parental pattern.

The Paniculata. Is a strong growing native variety.

The Maculata. Is of a more dwarfish habit. These two have been hybridized by European florists, till now we have perhaps a hundred choice kinds.

The Divaricata. Is yet another variety of our natives.

Phlox Drummondi. Was found growing in Texas by a botanical collector, Mr. Drummond. He sent the seed home, but soon after died of the fever, so this varicty, which is an annual, was named from him. This has been greatly improved, and it is claimed that some of the finest perennials have a strain of the Drummondi. The plants should have the best of care. They need water in hot, dry weather. I have known them to stand up well under 110 in the shade, with the hot wind raging, provided they had plenty of water.

SOME OF THE VARIETIES-TIIE WHITE.

Independence. Is a full, snowy white, one of the early ones. It is a free bloomer and quite attractive.

Jeanne d' Arc. Is massive, fine and late, a great mass of purity.

The Pearl. Is another very fine one.

But the grandest of all is Fraulein G. Von Lossburg. This is far in advance of any white one yet produced. The flowers are of glowing, sheeny whiteness, and are of immense size, sometimes measuring nearly two inches in diameter. These are very rare, and so are quite 
expensive. But in this superb variety you have the very triumph of horticulture, showing the wide contrast between this new creation and the original stock.

Coquelicot. Is French for poppy. This is flaming, bright, orange scarlet, almost the color of the brilliant oriental poppy. They are the brightest of all, but our hot suns are almost too much for them. They should have some shelter from the fierce heat of July.

Crepuscule. Has a flower larger than a silver dollar. It has a compact, massive head, as though it was one large blossom. The blooms are white, with violet shade, and a large, bright, carmine purple eye.

Huxley. Is violet purple, with a large center of pure white.

Esperence. Has a lovely shade of light lavender pink, with great lustrous eyes of white; compact, a free bloomer, and very beautiful. The head is like a great, solid, symmetrical cone of beautiful shadings.

Cross of Honor. This is not a large flower, but is rery peculiar, on account of each petal having a clearly defined cross.

Eclaireur. Has flowers of immense size. They are bright violet purple, dazzling in their splendor. In the center are marks and stars. This, by some, is considered the finest of all. It is one of the earliest. The stem is dwarf, but not the flower.

Amarante. Is dark violet amaranth.

Bacchante. Has enormous flowers, deep rosy carmine, with purple eyes. 


\section{DUCHESS D'ORLEANS.}

This variety is remarkable in that it has variegated foliage, the leaves being bordered and mottled with white. Flowers are salmon color-a very distinct variety.

Emanuel. Is very rare and of unusual color-violet blue, with purple center.

Le Soliel. Is light rose, shading to white near the eenter.

Lord Kelrin. Is very large bright red.

Lothair. Is salmon red, with carmine eye.

Ornament. Is bright clear rose, with very large prramidal panicles. 


\section{IIBRAEYT. \\ Division of Horkiculture, \\ N. C. Don"t of Agrioyletres.}

\section{CHAPTER XVI.}

\section{THE PAEONY.}

This flower is the highest triumph of floriculture. It is the hardiest and has the widest adaptation of all. It flourishes north and south, east and west, and thrives up to the Artic circle.

Many varieties have the fragrance of the rose, often surpassing it in form and loveliness. Some have the odor of the pond lily, others the perfume of the heliotrope, and some are cinnamon scented. With a proper selection of early and late varieties they continue in bloom from six to eight weeks.

In handling them they are so hardy that losses can seldom occur, and invariably you plant a success instead of a failure. They multiply rapidly instead of growing less and less and going out entirely as is the case with many valuable plants. They are seldom troubled with disease, and they do not suffer from insect pests such as often destroy the rose.

They are both patrician and plebeian in character. They will grow and bloom as well in the gardens of the poor as in costly estates of the rich. They are the joy of the poor girl as well as the lady of fashion. Their cheerful faces are an antidote for the blues. 


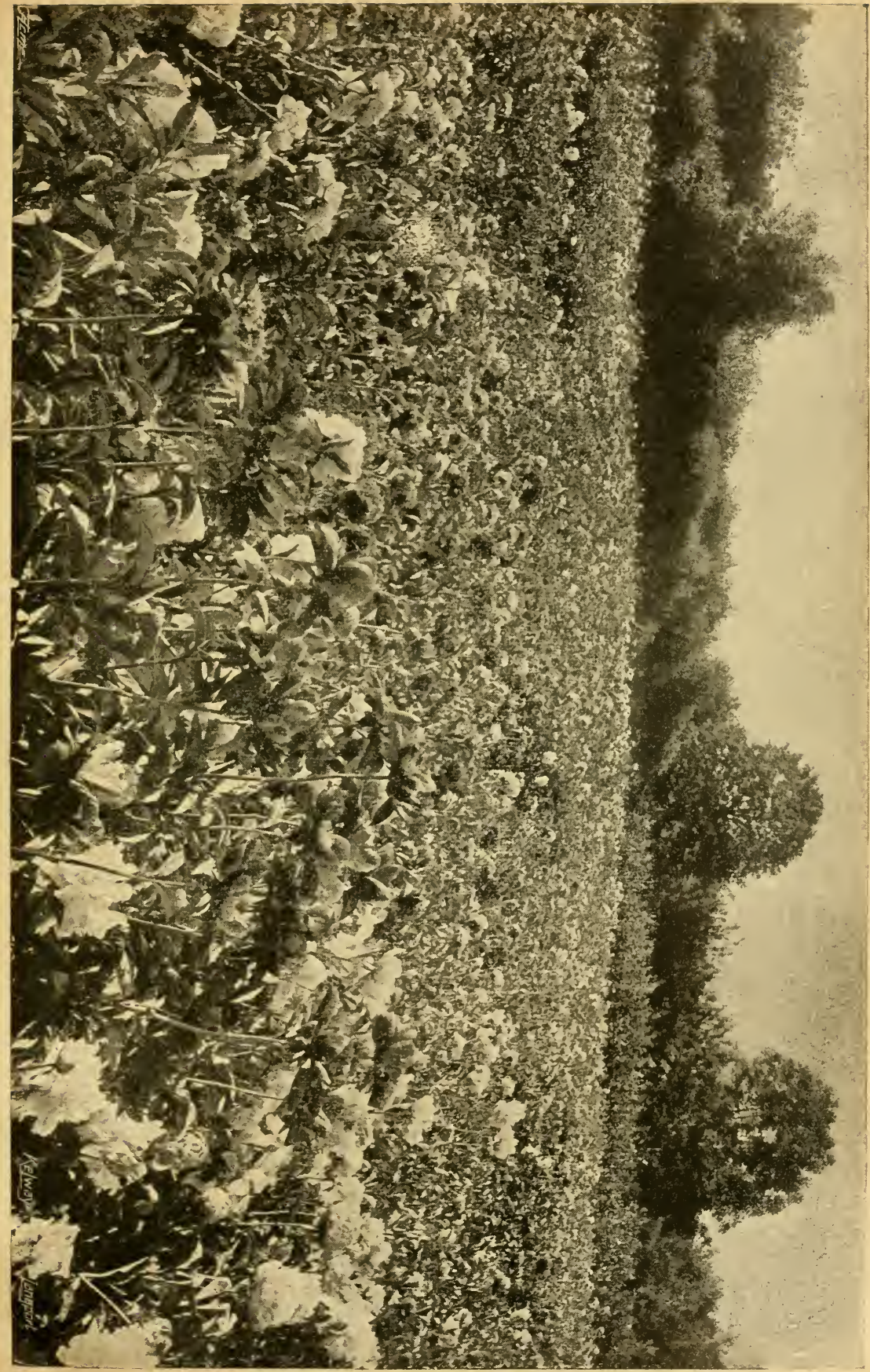



Every blossom is a smile of Providence, showing that God is near, giving choicest gifts to men.

They are the interpreters of the unseen love which is lurking in the shadows waiting for a revelation to the toilers and the despondent.

No more heroic flower ever bloomed.

In the great prairie empire, so dreary and vast, Where roses are slain by the terrible blast, Where siroceo and blizzard in tournament vie, And flowers of the Eastland grow homesick and die; Where gardens are lonely and homes are forlorn, There bravely our queen lifts her beantiful form And laughs at the tempest and smiles at the storm. And mothers whose eyes have grown weary with waiting,

And girls whose sweet spirits for beauty are aching, Shall smile on the march of our glorious flower, And souls that are hungry her beanty devour. No more shall the homestead be sad and forlorn, An invasion of beauty the land shall adorn. How sweetly her blossoms the senses beguile, And the weary revive with the breath of her smile.

What tremendous strides have already been made, and the successes of the past are only prophecies of the future. Fifty years ago there were only twenty-five varieties. Now there are over 2,000 named, besides thousands of others in the background. An interest is being awakened unknown before.

One man has recently planted 35 pounds of the choicest seed he can gather, and hundreds of others are 
endeavoring to call out of the unknown, choicer ones than have yet been discovered. No flower so richly rewards the propagator. Among a thousand seedlings there may be only one of superior excellence, yet each one will be distinct from the rest, and not a poor or worthless one among them all.

To show the awakening interest in the fall of 1904 the leading papers of the West, aggregating a circulation of over 300,000 , have given special illustrated issues awakening an interest in the great empire of the Northwest, where such flowers are so much needed and where they succeed so well.

There is no plant or flower on earth which gives so much pleasure and profit and so richly rewards its friends.

CLASSIFICATION OF THE ORIGINAL VARIETIES.

I have spent much time in the endeavor to search out the original families of this remarkable flower. From the number we judge that there is yet great room for progress, and perhaps we have only just begun with our hybridizing. By permission I quote from J. W. Manning, in "American Gardening," of March 5th, for which I tender grateful acknowledgment:

"Until the forthcoming Paeony list of the American Paeony Society is published, I believe quotation of variety names should be used with great care, and believe that the best interest may be served by giving the following list of species and their distinctive characters: 
Paeonia Albiflora, Pallas. A Siberian species introduced about 1756 , and one of the forerunners of the hybrid herbaceous forms, two to three feet high, with deep, rich green, often veined red, leaflets, and bearing clusters of three or more very large, broad, overlapping petaled white to light pink single flowers, and showing globular masses of golden anthers in the center of each. June. Reevesiana, Fragrans, Whitleyi and Festiva show close affinity to this species.

Paeonia Anomala, Lins. From Europe and Asia, with finely dissected, smooth foliage. Solitary, single, bright crimson flowers, and distinct in the large size of the petals and the peculiar compound, leaf-like sepals. Two feet. May. Its varieties, Insignis, Peter Barr, Smoutti and Intermedia are now recognized, being more distinct in the character of foliage than otherwise.

Paeonia Arietina, Anders. A tall south European species, distinct in the stems, being hairy toward the top; the foliage quite glaucus and downy beneath. The flowers are large, dark red and solitary, and the seed pods are prominently covered with hairs. The varieties range through shades of pink and red.

Paeoni Browni, Dougr. A northwest American dwarf species with glaucus foliage and dull, brownishred flowers, borne on re-eurved stems.

Paeonia Broteri, Boiss and Reut. An early-blooming, European species, similar in foliage and habit to Paeonia Officinalis, with red flowers varying to white.

Paeonia Coccinea. A reported species in the Royal Botanical Gardens at Glasnevin. 
Paeonia Corallina, Retz. Asia Minor. A vigorous species, two to three feet high, with dark green foliage, the lower leaves of which are only twice divided. Bright crimson flowers, with short, rounded petals and seed vessels of a bright red color.

Paeonia Coriacea, Borss. Similar to Paeonia Albiflora, with even broader leaflets, bright crimson flowers, purple stigmas and smooth seed vessels.

Paeonia Corsica, Sieber. Closely related to, if not the same as, the last.

Paeonia Decora, Axders. From southern Europe. A close species to Paeonia Arietina, with peculiar horizontal foliage diminishing toward top of the stems, which are two to three feet high. The crimson flowers are small, with few narrow and small petals. Pallasii, with narrow leaflets, and Elatior, with broadly oblong leaflets, are recognized varieties.

Paeonia Emodi, Walu. A Himalayan species, two to three feet high, closely related to Paeonia Anomala, with smooth, finely cut foliage, pale beneath. Flowers pure white, borne in clusters of four or more.

Paeonia Humilis, Retz. A French species of low growth, with somewhat velvety foliage, and with bright red flowers on short stems, and borne in clusters of three or more, with smooth seed pods.

Paeonia Lutea. Recently discovered species from Yunnan, and introduced by Abbe Delavay, growing about two feet high and bearing small, bright yellow flowers. The plant is somewhat shrubby in habit, and 
allied to Paeonia Moutan. Not sufficiently tested as ret as to hardihood.

Paeonia Microcarpa, Boiss axd Reut. Closely allied to P. Humilis, with even dwarfer habit and more downy foliage. Presumably a native of France.

Paeonia Mollis, Axders. A dwarf Siberian species, with dark green upper surface to foliage, and distinctly glancous and velvety below. Flowers pink or red, and borne singly.

Paeonia Moutan, Siss. The well-known Tree Paeony, a native of China.

Paeonia Officinalis, Lrsx. The oldest cultivated species, first grown in 1548, with dark green foliage above, pale green beneath, growing two to three feet high and producing single, dark crimson flowers, and with recurved crimson stigmas. Early blooming, and a parent of many double anemone-flowered and semi-double varieties. A native of Europe.

Paconia Paradoxa, Axders. A very dwarf, almost tufted, Turkish species, with three-lobed incised foliage and purplish red flowers borne singly, and with seed ressels closely pressed together. There is a variety, fimbriata, with double purple flowers and projecting purple stamens.

Paeonia Peregrina, Mrtu. A European species similar to Paeonia Officinalis, but with very smooth, deep green foliage abore, pale green, hairy beneath. Flowers bright crimson. This has given rise to two good double forms and a number of varieties with single whorls of petals. 
Paeonia Obovata, Muxim. A little known species, with "lower leaves not more than twice ternate; flowers large, red-purple, and glabrous sced vessels."

Paeonia Pubens, Simss. Allied to Paeonia Arietina. Leaves hairy below, margins red.

Paeonia Russi, Brovox. A Sicilian and French species varying from Paeonia Corallina in decidedly hairy undersurface of foliage.

Paeonia Sessiliflora, Sims. Nearly related to Paeonia Mollis; very low; flowers short-stemmed, pure white.

Paeonia Tritemata (Daurica) Pallas. Three feet. Differs only from Paeonia Corallina in the rounded leaves, greener stems and rose-colored flowers. A native of Caucasus.

Paeonia Sibrica. A little known species in the Glasnevin Royal Botanic Garden list.

Paeonia Tenuifolia, Lixx. (Abbreviation of Linneus.) A Caucasus species eighteen inches high, with light, soft green, very finely divided foliage, and dark crimson, yellow anthered flowers and spirally recurved stigma. The earliest blooming species. There are double and semi-double types of this.

Paeonia Wittmanniana, Stev. A Caucasian and north Persian species about two feet high, with coarsely divided, dark green foliage, downy beneath and bearing showy, incurved, pale yellow flowers, one to a stem. Rare. 
PROPAGATION.

It is highly important to know how to multiply these valuable flowers, for the process is slow at best.

Tou buy a choice Syringa or Philadelphus, and you can divide the roots and plant cuttings and increase them very rapidly. You can, in a few years, run a new kind of a fruit tree up into the millions, but you cannot rush the Paeony. One of the best on the list originated in 1835, and it is impossible now to supply the demand. If you raise from seed you never reproduce the original, and it takes from five to eight years to know what you are getting. But with care, by root division alone, you can secure from one to two thousand in ten years. There are three modes of propagation,-by division, from roots and from seed.

We have a different system, where we raise for roots, than where we propagate for flowers. By the best of care on the richest ground you can hurry them considerably. But there is a great difference in them. I'Esperence and Victoria Tricolor multiply rapidly, while J. Discaisne, though a glorious flower, wants about four years to double itself. Others equally as good in bloom are much more profitable. From Baroness Schoder, La Tulipe and Richardson's Rubra I have cut thirty roots in four years from one. By dividing every two or three years you have perfectly healthy and vigorous roots. I have bought those that must have stood twelve or fifteen years. The buds were partially decayed, and they had great, club-like roots. There is no advan- 
tage in such large roots. A two-year-old plant, sound and vigorous, is much to be preferred.

A neighbor wished me to do something for his Paeonies. They had been twenty-five years in grass and weeds. They were crowding and exhausting each other. They would bud, but had no vigor to expand the bloom. I took up great clumps, and found them much decayed. I cut them up, planting the buds and what little root I could secure with them, and in two years had as strong and vigorous stock as I ever saw. My land consists mostly of city lots, so I must plant closely in rows, about eighteen inches apart, and eight inches in the row. Of course they could not stay long. I have the advantage of irrigation if necessary. I have often planted buds alone, with no root whatever. One fall I put in thirty, and the next year had twenty-seven fine plants.

DIVIDING THE ROOTS.

This is difficult, and requires patience and judgment. Some have a distinct cleavage, and are easily separated. Others, like Marie Lemoine, have no cleavage, but are gnarled and twisted. Some, like Princess Ellen, have roots like a ball. Many are very tender, and as you begin to divide, they will snap like pipe stems. This is bad, for there are the roots, and you need them to go with the buds. If you lose them it will take a year or two to replace them. Let them lie in the shade a few hours and wilt. This toughens them and does not hurt them a particle. You can immediately restore them 
to their plumpness by putting them in wet moss, or keeping in or planting in moist earth. This is a very important matter. I got onto this process after a good deal of annoyance and vexation. In planting, have your ground in the best of order. I have deep, rich soil, fertilized with hen manure when I can get it; only prepare your ground beforehand, so the fertilizing will be assimilated. Make a deep, wide hole with the spade, insert the root, press the earth close about, put the bud two or three inches below the surface, and be careful not to bruise it. It is a good idea to put a coat of manure over them in winter.

\section{PLANTING FOR FLOWERS.}

You can raise roots and blossoms at the same time, but you cannot multiply as rapidly as where you raise solely for the increase. Of course you will raise many flowers while you are propagating. The ready bloomers will get in their work the second year, and at that. time we often have quite a burden of bloom. Some sorts require time to come to their best. Usually the largest and latest sorts need a year longer than the others, while some kinds will bloom on the least provocation. Tictoria Tricolor is noted as an early, prolific bloomer, and a ready multiplier. It often blossoms the first year.

To raise the largest and finest flowers, the ground should be very rich. We often cart on soil and manure to increase the depth. Rich, bottom land, well manured, is best. The ground to be planted in the fall 
should be prepared in the summer. It should be spaded two or three feet deep. Plant in rows four feet apart and three feet in the row, so you can cultivate with the horse, if necessary. Sometimes I have prepared ground in this way: On an eighth of an acre there were scattered eight loads of hen manure, and a strong team plowed it two furrows deep and took the whole day for it. This thorough preparation is necessary for the best results and the largest blooms. Of course you do not have to be at such expense. They will grow, thrive and bloom on good corn ground. By this process you are raising roots as well as flowers, and at the end of ten years you will have an enormous crop of the former, but they will be large and not so easy to handle.

In planting to raise flowers, be sure to take good, strong roots. Such will come into bearing much sooner than small ones. I should not plant clumps, but heavy ones, and they will make the clumps soon enough.

I have gone into detail because I deem the Paeony the queen of flower's, and it should have the best possible chance.

RAISING FROM ROOTS.

I have watched this process closely for years, and have found one thing, perhaps not discovered by others. The root is small where it joins at the top; it swells in the center and then tapers. Now if a root is broken at the center, the lower portion never can form a head. It will try hard. A callous will be formed 
at either end. The poor thing will do its best to put a head on itself, but cannot make it. At the end of the first year the root will yet be sound, the second year the top will begin to decay, and the third year it will be rotten. The upper portion of this same root, where it breaks from the plant, will have a good show for forming a head. Kinds differ. The Edulis Superba and others of its class are stored with vitality. I have often stripped off ronts, like fingers from the hand, and planted them, and almost invariably a bud would form the first year and be ready for business the next spring. Sometimes it will take two years to form a head, but in the main you will succeed better to carefully divide and plant root and bud together.

A good way to accelerate the development of roots and latent buds is to pack in moss or moist earth, and keep them over winter in a cellar which does not freeze. I have often known roots to develop twice the buds they had before, and those with no buds at all by spring would have some fairly well started.

\section{PROPAGATION BY GRAFTING.}

The propagation of the pacony as compared with fruit trees and shrubs is slow at best, so grafting is often resorted to.

Understand, every paeony root is anxious to live. We show elsewhere how a root will work three years forming a callous at either end in the effort to live. Take a root far enough removed from what we term the crown, so it cannot develop a bud of its own, and 
by the cleft graft system insert a bud of some choice variety. The root will rather rejoice that a head has been given it, and will throw out roots to match it, while there will be no danger of its reproducing itself. Thus the roots of common vigorous sorts can be made to accelerate the production of the costlier kinds. Grafting should be done late in the fall or winter. The grafts and cleft in the root should be carefully waxed and laid away in damp moss. Then place in a cool cellar till spring. It would be better not to have them freeze, though freezing would not seriously injure them.

A paeony specialist just writes me, "I have some plants the eyes of which alone are worth $\$ 1$ to $\$ 2$, and what shall I do with them?" I gave him the foregoing process, which I am sure will succeed.

Suppose you get a choice root of some variety for which you pay $\$ 3$ to $\$ 5$. It has only one good vigor= ous root, and perhaps half a dozen eyes-more eyes than the root can carry to advantage. Now you can cut off the eyes and put in moist earth in the cellar, and each one will throw out tiny roots, and in the spring you can put it out carefully. Shelter it a little from plunging rains, and it will make a plant. It may take two or three years to make a saleable plant of it. By grafting you would have speedier resilts.

\section{RAISING FROM SEEDS.}

We must pay more attention to this. There is no reason why we should not produce more rare sorts. 
There is a fascination here. You never know what is coming. Just beside you, in the unknown, there is a rare, lovely and fragrant flower waiting to surprise you. You wish to give it a chance to materialize, so you are on the alert to welcome your new creations. One in a hundred will be fair; perhaps one in a thousand will be superior.

How about hand pollenization? I should let the bees attend to that.

Note this fact: You must secure seed from the VER CIOICEST KIN⿴囗十. Tere we are handicapped. Great, splendid ones, like Festiva Maxima, Tecumsch and Richardson's Rubra Superba, can go no further. Those grand, double ones have reached their limit. It is well-known that the single and semi-double are very prolific, and yield any amount of seed. When Terry and Rosenfield, in the west, commenced their work, they secured seed from the very best. Thirty vear's ago Mr. Terry began with seeds from the choicest flowers that would yield any, and he has given us some fine ones. So with Rosenfield, who gave us Floral Treasure and Golden Harvest, that now stand well at the head of the procession.

Other propagators I know of have used, I am sure, seeds from inferior plants, and as like begets like, they have very inferior strains. One grower, by a good deal of enthusiasm and fulsome praise, lias sold sevcral which prove to be a disappointment. The whole stock, with a few exceptions, is coarse and cheap, and does not sustain itself. It is remarkable that you may 
raise a thousand seedlings, and there will be no two exactly alike.

What shall be done with the thousands of rejected ones? We have too many named ones already, abuut two thousand. Shall we throw them away? By no means. If you had never seen a Paeony and were introduced to the thousand left behind, you would call them fine flowers, and so they are. In the hosts of these common, ones I never saw a really poor one. They are all good, but there are the better and the best. I would say keep them. They can be used for parks and in masses. Put them on your cheap list and classify them in colors. There are many people who insist that a "piny" is a "piny," and that is all there is of it, and they will insist that you keep a "bargain counter," for they think they are terribly cheated if they have to pay more than twenty-five cents for a "piny." They are much like the young darkey who, by mistake, got a license to marry Lucinda, when he had agreed to marry Katie. It would cost him something to get a new license. He proved equal to the occasion, "Dere ain't no $\$ 1.75$ difference between dem two niggers, and I'll just marry Lucinda."

We are glad to note cheering success in originating new varieties in America. We need to go in on a larger scale. Mr. Kelway, of England, and Mr. Terry, of Iowa, have given us over 100 each. The main difference between them is, Kelway has used the most ink. I think Terry has never photographed one of his grand creations. We are happy, however, to present some 


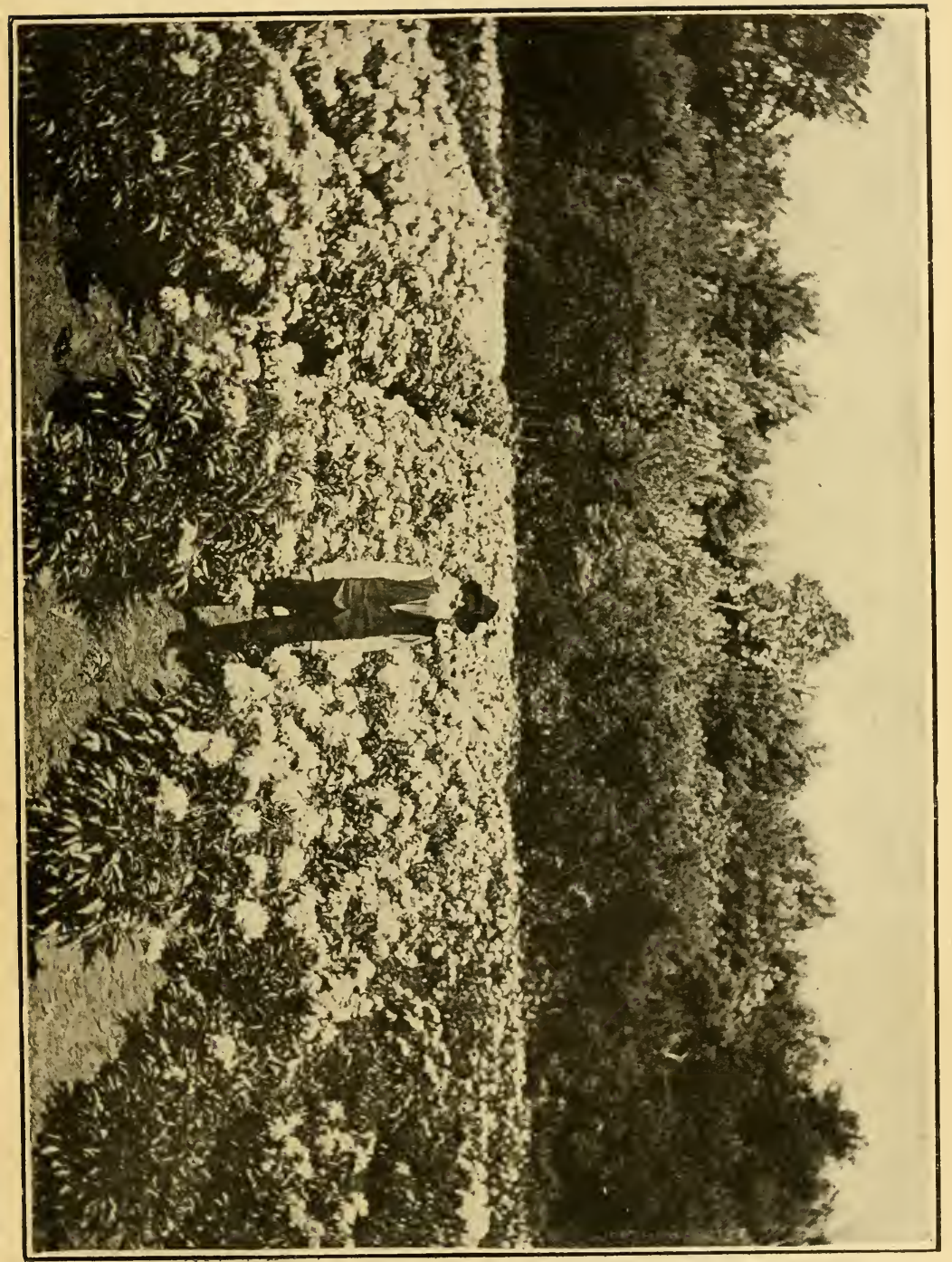



in this Manual. I think it would be much better to go heavily into the business of propagation than to send so much money to Europe and import so many disappointments.

There is a future for this industry. For instance, the new Japanese, with their peculiar stamens, are very unique. I have about twenty-four kinds. They seed readily, and, having them hemmed in with other fine varieties, I have great hopes of a new race of hybrids. I also intend this fall of 1904 to plant about two quarts of the very choicest seeds that I can secure. I have large quantities of my own and have engaged more, and from the coming thousands I hope to see some of superior merit. As to those which will not be named, keep them. The great empire of the Northwest will need them. Most of those raised by Western growers yet go East, and the bleak Northwest is waking up to their merits, and will yet absorb millions.

\section{CARE OF SEEDS AND PLANTING.}

It is better to gather the seeds before they get thoroughly dried, and plant immediately, or mix them with moist sand and plant just before the ground freezes. In the West, often our falls are so dry that seed, at the ordinary depth, would dry out. Those can be planted that are thoroughly dried, but it takes two, and even three, years for them to germinate. They should be planted in rows about two inches deep. If, in the spring the ground should incline to crust, it may need pulverizing with a rake, so that the little plants can 
come up readily. If sown in a seed bed they can be removed when a year old. Though the roots will be small they will be full of vitality. If far enough apart so they can have a fair chance to develop, it is better to let them remain till they bloom. But it takeș some years for them to fully show their individuality so you can know what to depend on. Don't be in a hurry. I have known rejected ones to develop flowers equal to almost any, and I have one which was discarded while young, which is now near the head of the procession. Young plants do not often go back, but show up better as they grow old. The Paeony has almost infinite patience, and you must have a little even in this age of steam and lightning.

\section{THE HARDINESS OF THE PAEONY.}

We know of nothing in the vegetable world which has the vigor and hardiness of this plant. The root is like the gripsack of the traveler, which contains the supplies for his journey. It will come to us from Europe and bring in compact form foliage, flower and life. We know of nothing that will stand more hard treatment, exposure and neglect. It may be left on the ground, exposed to the sun, for days, and be badly withered, and yet it will revive and grow. Often we find, where we have cut up plants in the fall, that tiny buds, so small as to escape notice, after freezing and thawing all winter, will throw out shoots and tiny rootlets, and we have often saved them. One spring two roots of La Tulipe were left in the barn two months, 
till, to all appearance, they were dead. They were planted the first of June, and they immediately revived and grew.

One winter we had several boxes stored in a root cellar. They were poorly packed. 'Some one left the door open and they were all frozen solid. The door was closed, and they remained frozen till spring, when they were planted, without the loss of one. It is no uncommon thing to keep a lot in boxes seven months at a time with but slight packing. I once had a remarkable experience with a lot from Kelway, England. They came over in reasonable time, but were delayed in a warm office at Lincoln, Neb., a month before I was notified. The box was dried out and full of cracks, and the moss was dry as powder. The roots were black, and snapped like sticks. The buds were shriveled. I had the expressman look them over, and all pronounced them dead. There were thirty roots, some of which cost $\$ 2.50$ each. Of course the express company had to pay damages. Taking them home about the first of November, I cut off the dead roots and planted the buds in moist earth in a box in the cellar. At the end of a month the buds began to swell. December 1st, they were planted out, and were frozen all winter. They all grew but one, and one of them bloomed. Of course it took an extra year to form new roots. They seemed much like the Mexican resurrection plant.

'They are like the Rocky Mountain burro that bear's any amount of misuse or neglect, and yet patiently 
plods along. Often for years they must bear neglect in grass, or the hard earth tramped solid about them. And yet they hang on, doing the best they can. Yet while they patiently endure so much, there is nothing that responds with more grateful alacrity to generous treatment. A neighbor had an Alba Sulphuria, which had bloomed in utter neglect for twenty-five years. I bought the clump, he retaining a couple of roots. He planted his in the grass and hard earth, digging but a little space for them. In four years they have not bloomed or grown. They could not. They could only live. I planted my part in the richest ground, and how they increased and blossomed. In about four years I had nearly one hundred plants.

All the great West and Northwest are well adapted to them, and. it should be a matter of encouragement that the finest flower that blooms will give its cheer to a vast region where other flowers cannot grow. They are hardier than the pieplant. We pay out millions for choice roses, and other things which cannot endure our winters. It is much better to plant an absolute success than a sure failure.

\section{"PLAYING POSSUM."}

Possessed of a marvelous patience, this plant will often bide its time, and seem dead, when it is only gathering its forces for a vigorous push.

One fall I planted quite a row of the splendid Princeps. Next spring not one of them came up, nor did they show any signs of life during the summer. I was 
preparing to use the ground for something else, when, after lying dormant for eighteen months, the whole row pushed up and commenced a vigorous growth.

When you dig a lot from the ground, there will be many spring up the first year, and often more will show the second year, having taken so long a time to form a head. It is my custom in cutting up, to replant the same row to the same kind, to aroid any mixture, and if I cannot do this I am careful to plant between where the rows were, so the strays will not come up in the same row with those I am planting, but between them.

\section{THOROUGHBRED LIVE STOCK AND THOROUGHBRED}

FLOTVERS.

I used to keep thoroughbred Jerseys and Shorthorns. Though I enjoyed it they were a constant care. One night I was awakened by a fearful crash. I wakened the boys and told them to bring the lanterns. Rushing out, I saw in the barn two balls of fire. They belonged to the Shorthorn. He weighed a ton, and every pound of him was in fighting trim. Aiming a pitchfork a suitable distance below those blazing orbs, I caught him in the nose. Then the lights came. We secured him and led him back to his stall. It seemed the Jersey got loose and thought it a good time to take revenge. The Shorthorn tore himself loose, drove the Jersey back to his stall, and, with one tremendous thrust, hurled him through the side of the barn. I was younger then, but I don't want any more. I have 
seen men who had built up a fine, choice herd of hogs; then came the cholera and wiped them out. Beautiful flocks of fowls melt away with disease, become the prey of sneaking beasts or the chicken thief.

It is different with thoroughbred Paeonies. They do not tear themselves in wire fences. You know where they are nights. They do not eat their heads off in winter. The food costs nothing. You can go off on your summer vacation, and they will be there when you come back. They multiply as fast as live stock. There is more money in them, legitimate, honest gain. Sixteen years ago a man laid out $\$ 50$ for choice strains. For some time he has been selling $\$ 1,000$ worth a year.

I bought a fine plant for $\$ 1$. In five years I sold $\$ 18$ worth, and had eighteen roots left. One choice variety in the same length of time brought in $\$ 34$, and I had fifteen roots left. One fall I had an order for 500 common mixed sorts for $\$ 6$ per 100 . It took but a small piece of ground to furnish them. My man, who had worked on the farm, was astonished. "Here," said he, "we have dug $\$ 30$ from a few rods of ground, and if we got that from two acres of farm land we would do well."

Is Paeony raising a fad, that will soon pass away? It cannot pass; people will not allow it. In staid old Europe the interest has fairly commenced. In our Eastern states, where they can raise Azaleas, Kalmias and Rhododendrons, the demand is on the increase. Most of the stock of Western growers yet goes East. In the West we cannot raise the flowers above men- 


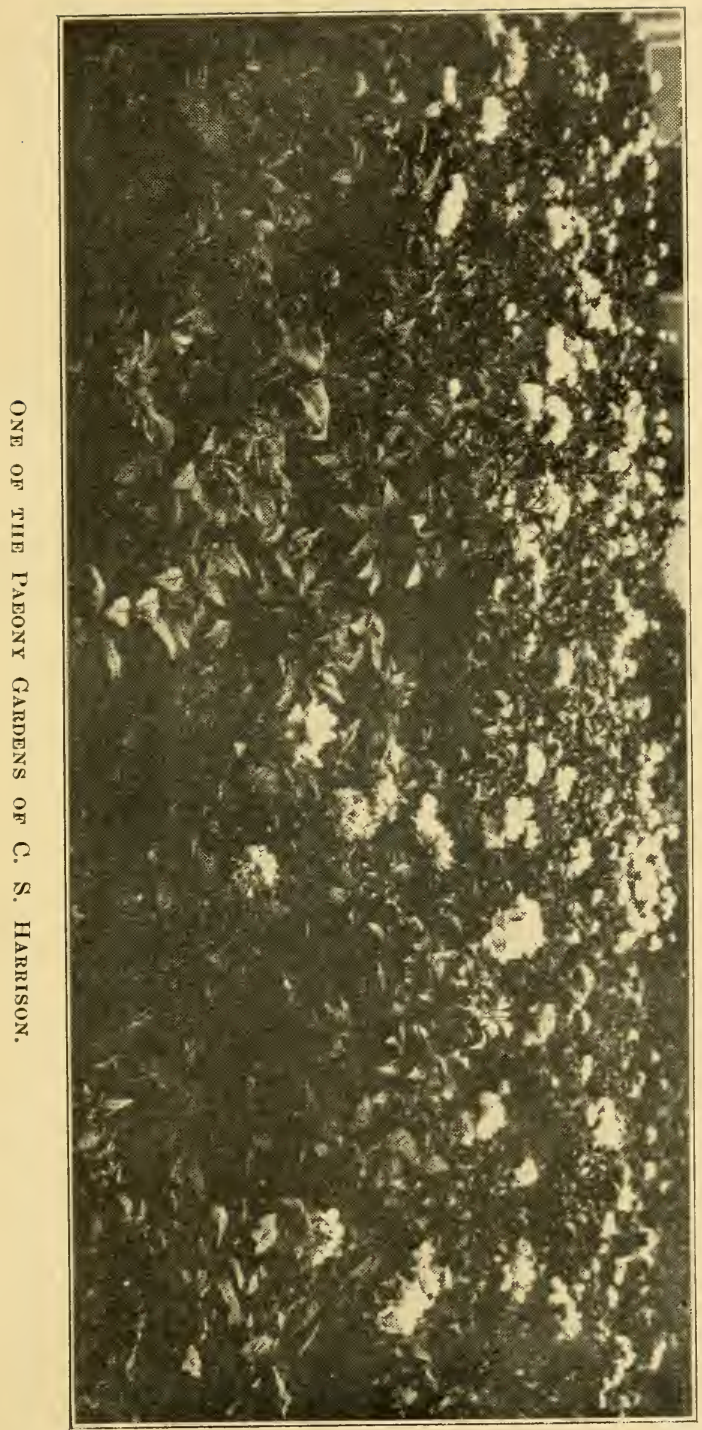



tioned. They will have nothing to do with us. They are aristocratic Easterners that will die before they will live with us. I thought our hot suns and drying winds too much, so I got 1,000 of the hardiest kinds I could hear of, and put them under a screen. Kalmias, Azaleas, Rhododendrons, all died in a year, despite the tenderest care. Do you wonder that we love a flower that will step in and take their places, one that never grumbles or pines, and is never homesick, that is more fragrant and lovely than the best of them? I have attended some of the most famous flower shows of the East, and here in Nebraska we can raise as fine Paeonies as anywhere on earth. We plant roses, and they kill down and dwindle away, but the Paeony stays by. us. Millions are needed for our Western states. Billions are needed for the Dakotas, Minnesota and Manitoba, where they do as well as in England. When the finest flowers on earth are fitted for such a vast empire, and they will grow and thrive where other things will not, you can depend on them.

Talk about Ginseng for profit! Go to raising Paeonies. This is work for ladies. Already many are going into it. There is much less care and expense than in raising chickens, though as light work the two go together. The hen is mightier than the sword. She seems insignificant, yet her produce and progeny every year are greater than the ontput of all the gold mines, and the more eggs and chickens you raise, the higher they get. The two enterprises are in woman's realm. Mrs. Pleas, of Indiana, has raised some fine 
new sorts. One she sold for $\$ 100$, and another for $\$ 150$, besides having thousands of dollars' worth of enjoyment from her floral friends.

When you take into consideration the growing value of cut flowers, you have three harvests from your Paeony bed, one in the spring, the blossoms in summer, and again root sales in the autumn. This delightful and profitable employment, together with the fascination of raising new kinds from seed, will give a zest and joy to living which cannot be found in any indoor employment. There is the delight of seeing a transformation going on, the brown earth putting on robes of beauty while you are calling forms of loveliness out of the unseen, taking the rainbow and moulding into shapes of wondrous fascination.

ADAPTATION.

The Moutan or Tree Paeony does remarkably well in England and in our Atlantic States. It blooms grandly and grows to be quite a bush. I have grown them in Nebraska for more than fifteen years, and find them very shy bloomers. They will grow and increase all right, but I think the buds are sensitive to our trying climate. It is possible these will do well where the herbaceous ones are not satisfactory. I think, as you go south into the Gulf States, especially into the sandy soils, the Chinensis will not be satisfactory, and perhaps those regions will be just the place for the Moutan. 
I understand they can be used successfully for forcing, and think this would be feasible. The trouble with those grown out doors is supposed to be the severe spring frosts. This difficulty would be obviated by bringing them into the greenhouse. In those sections where you can depend on them, the blossoms are of resplendent beauty, some of the newer sorts almost as large as a dinner plate.

They are usually propagated by putting a slip into the fleshy root of the herbaceous kinds. It will use this for a time and then discard it for its own. The stools can be readily separated, and if you wish to increase faster, graft the tops on their own roots much as the nurseryman does his young apple trees, using the lip or splice graft. Care must be taken, however, to let them knit well before planting out. But if you have patience you can wait for the root division.

The Tenuifolia are the earliest of all. They are single and double. They are not quite as hardy as the Chinensis, as they need mulching in the West in winter, where the cold will be excessive and sometimes there will be no snow. I have had them bloom as early as May 5th. The blossom is like a rose, seated in that delicate, soft, fern-like foliage. The only drawback is, it is not fragrant. Yet it has an important place to fill.

The Officianalis is the "piny" of our mothers. I remember with a shudder the steeping of the "piny toes" for the ills of childhood. For years I looked with contempt on the whole family on account of the 
rank and disagreeable odors which came down out of the past. Though this has been one of the mothers of the new and fragrant race, yet much of the indifference regarding the modern flower dates back to the memory of the sickening odor, so indelibly impressed on childhood.

Again, they are not hardy in the West and Northwest. Thousands have planted them and failed, and think the whole family a fraud. We get letters from Minnesota, telling of failures, and in every instance you trace it back to the same old "piny." Six years ago I planted a dozen good, strong roots. The first winter eleven of them died, and it took the survivor six years to furnish one bloom. No wonder, when people judge from these, that they are prejudiced against the whole. The Officinalis multiplies slowly. Others, beside this lone one, have blossomed gloriously and increased rapidly.

I know there are clumps here and there in Nebraska, and when once established and not disturbed, they give early blossoms, following hard on the Tenuifolia. Both these kinds have an entirely different system of roots from the Chinensis, - - something like clumps of sweet potatoes. In separating them, as in case of the dahlia, you must have a bud go with the root. So please bear in mind, if you live in the bleak Northwest, that you are never to order the Officinalis. 


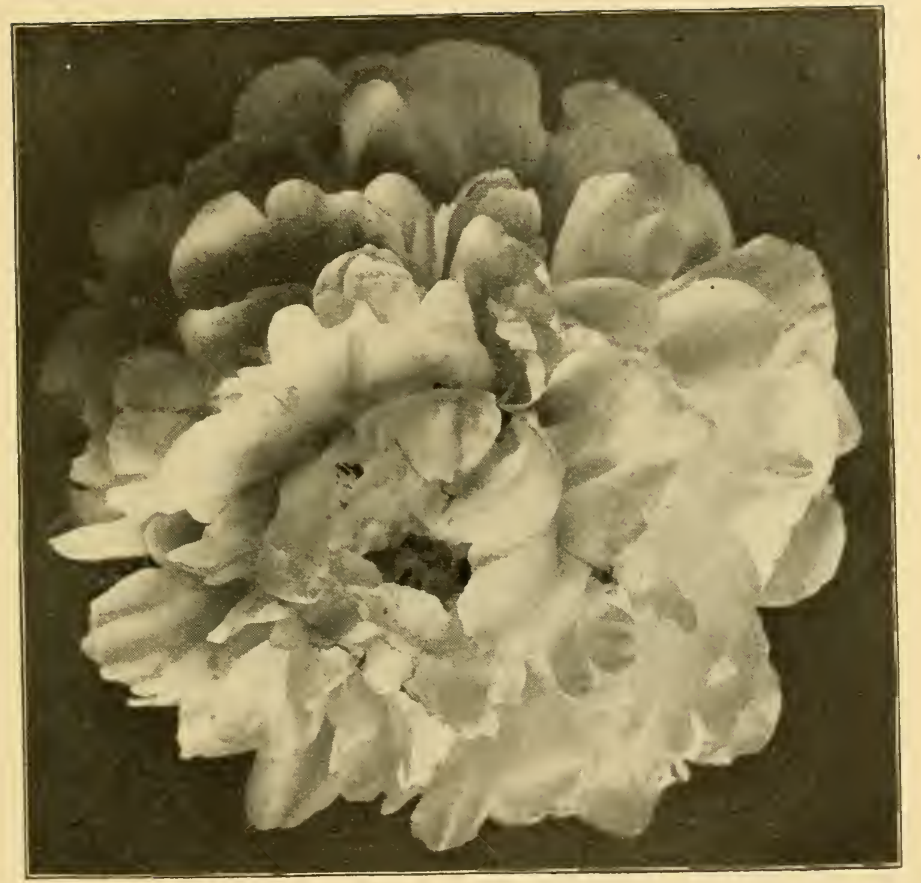

The festiva maxima. 



\section{CHANGES OF SOIL AND CLIMATE.}

Some kinds are more sensitive to their conditions than others. Many varieties of fruits which do well in one locality are worthless in others. Some of these flowers will do better in certain. soils and climates than others. Baroness Schroder is called flesh colored in England. In Massachusetts, sometimes, instead of being pure white it has a grayish tint. In Nebraska it is of snowy white, and one of the most perfect flowers that ever bloomed.

Charlemagne is called an enormous flower in Rochester, but it has been something of a disappointment in other locations. We must not condemn a variety as a fraud if it does not meet our expectations, for it may be a success elsewhere. While we say this, there is probably no flower that does so well under varied conditions. Difference in soil will have something to do with it. Of course it cannot do as well in light sand or stiff clay as in the rich loam of the West.

For instance, some apples which do well in the East are of no account in the West. It is so with all kinds of hardy fruits. So we must give a little chance for the Paeony to show its preferences. Giganthea is a fine, early pink, producing an enormous flower. It is popular and satisfactory in the Atlantic States. Testing it three or four years, it does not come up to its Eastern standard. A large single one said to be nine inches across and a splendid flower in Indiana has absolutely done nothing for five years in Nebraska. It 
may rally in time. Generally, Paeonies will do the best they can, but some do seem a little sensitive to their conditions.

\section{MISTAKES AND MINTURES.}

There has been no end of trouble from these causes. As we have had no Paeony society till recently, we have had no check on loose methods. So one name has been given to several different sorts. Often the choicer the kind the more substitutes it has. At least six kinds have been sold for Festiva Maxima, and one of our best firms innocently sent out Grandiflora Alba for years for this variety. There has been no end of confusion regarding the genuine Humei or Thorbeckii, one of our rery best. I have bought from many of our leading firms those bearing this name, which were not even distant relatives of it. It is so with the Duke of Trellington.

Holland firms are notorious for their carelessness. I bought of - They were not what I sent for. They insisted that they were, when I returned their own labels and my order. Then they were not true to name. About that time I bought quite a bill of an American firm, and they proved the worst mixtures I ever saw, though they were packed with the greatest care. I notified them. They supposed they were all right, for they got them of —- So many of the Dutch firms are so umreliable that we are sure of nothing. Before me lies a letter of one of our leading growers. He has had no end of - rexation. Such 
methods are in wide contrast to most of our American firms. Visiting the grounds of Rosenfield, I found he had the different kinds in beds by themselves, and while blooming every plant was watched, and if perchance there was a stray, it was marked with a stake.

A noted firm in England, which has done more to bring this flower to the front than anyone else, has fallen into careless ways. So one dealer says, "TTe get only the sweepings of their ficlds." This is bad, for we supposed we had a firm we could absolutely depend on. 'Their prices were very high, but we dirl not care so much for that, provided we got pure stock. Some time ago I sent for two roots of Lady Alexander Duff, supposed to be the best Paeony on earth. 'They were five dollars a root. I watched them grow, and had my friends look at those plants which were to surprise us with the grandeur of their bloom. When the flowers opened we looked on in a daze of expectancy, when lo, they showed us some inferior single blossoms, on stems about a foot high. They were very short lived, the petals falling in two days, along with our expectations. They were just fair 10-cent plants. When I ordered, I charged them to return the nomey if they did not have the genuine plants.

What is the lesson from all this? Patronize American growers. They are responsible. They keep as good kinds as the world produces, and will gladly correct mistakes. They do not hide behind an ocean. TWe must go to raising new rarieties on a large scale. Our 
growers have now hundreds, soon to go on the market, as fine as we import.

\section{DIFFICULTIES.}

Where one has several hundred varieties it is hard to keep the stakes all right. The weather will wear off the names in a few months, and they must be re-marked with care. Sometimes the stakes will be broken down. Perhaps an inquisitive visitor may pull one up to read the name and set it back facing the wrong way. So, with the greatest care, mistakes are inevitable. I have bought of the leading firms of America and Europe, and have never yet found one which did not have more or less mixtures. Of course, among the most careful, the strays would be insignificant. Anything serious, of course, is corrected as soon as possible. This goes to show that very few of us are infalliblc. One. of our western growers was sick, and hired a man to plow out his plants, and he, like a "wild bull in a china shop," knocked down most of the stakes, so the plants had to be sold as a mixed lot.

\section{THE PROPER WAY.}

is to wait till the plants bloom before stock is put on the market, unless you have it from some reliable firm. If mistakes occur, rectify them as soon as possible. I find the best way is to have good, strong stakes, at least two feet tall, painted, with the bottoms dipped in coal tar.

I know one dealer who received a very abusive letter from a purchaser who bought two years before, and 
claimed that in quite a bill they were all spurious, and he wished he could find an honest man to deal with.

The dealer replied he supposed he had received the stock from a reliable firm, and was sorry for the disappointment. He told his customer he could not afford to and would not receive any more such letters, and he immediately packed and sent quite a bill of choice varieties which he had tested, amounting to twice as much as the original bill. Of course confidence was established after that.

Never denounce a man till you have given him a chance to rectify mistakes. I have bought certain kinds from four different dealers and every one of them were different, though the dealers may have been honest. You might send to three men for Queen Victoria and each would give you a different kind, and honestly, too, for there are three bearing that name.

KEEPING TIIE PAEONIES BACR IN TIE SPRING FOR SELIING.

We do not all of us have cold storage, and unless very cold, they will start, if kept moist, at a very low temperature. I have kept boxes of Paeonies frozen, and as soon as the frost was out they began growing. It will not do to leave them in the field if we expect to sell them, for buds grow rapidly and are very tender, and often orders come in when the plants are two feet tall. Of course it is not a good time to plant, yet cus- 
tomers want them as late as May, and are disappointed if they cannot get them.

It is very easy to keep them back. Instead of packing them in wet moss, which would bring them forward immediately, keep them cool and dry; even if wilted a little it will not hurt them. One spring I received a lot from France. They came late, and were packed dry in an open basket. They were badly wilted. Placing them in water a short time revired them. They lived and grew, and some of them bloomed the same season. Of course it is not necessary to keep them very dry. They can be placed on a rack, like cannas or dahlias.

\section{LATE BLOOMING.}

If you wish to continue the flowering season into July, take large roots with plenty of buds, and keep them partially dry, as noted above, or in cold storage, and plant out from the middle of May till the first of June. But there may be this trouble about July blooms: In Kansas and Nebraska the sun gets very hot, and delicate flowers might have the sun scald. I have seen this sometimes in the case of Madam Chanmy, which is a large, late and very beautiful flower; also with Richardson's Perfection. Where there is any danger, set up stakes and stretch gunny sacking over them. It is well to plant those for late flowering in groups, so they can be easily protected. 
IN PLANTING, THE CONDITION OF THE BUD MUST BE TAKEN INTO ACCOUNT.

This is very important. The Paeony usually goes into a dormant condition about the middle of Angust. I have had excellent suceess in planting at that time, for the buds that form for the next spring are small and tough, and they ean be handled withont danger of injuring them. As a general thing, however, September is the best time, for if very hot in August it will not do to ship. If packed too moist they might rot. When planted at this time little rootlets begin to grow and the plant is all ready for its spring growth. You will notice that those left in the ground and apparently dormant are making a fine growth of fibrous rootlets, and the longer they are left the more numerons they will be. The buds are growing too, and often old roots will have a net of rootlets around them, and the buds will be much larger and more liable to damage than if planted earlier. Of course Paeonies can be planted any time from the first of September till the middle of the following May; but we are speaking of the best time. I have often planted strong, left orer roots from the first to the midlde of May, and if the ground is rich and in the best condition, hare cut good crops of flowers from them a few weeks after planting.

There are varions ways of lengthening the flowering season. A lady had occasion to dig a cellar, and eightcen inches of dirt were thrown over a strong clump. She supposed of course they were dead, but two weeks 
after the rest were up these came on, blooming so much later than the rest. It would not do to try this, save on strong, well established clumps. I have heard that mowing off the tops when they are a few inches high would retard them, but never wished to try it.

This plan works well: Suppose you have a row ten rods long. At one end you have no mulching; then you put on a little, increasing it till you put it on a foot deep at the farther end. The covering should be put on when the ground is frozen solid. You will note quite a difference in the same row in the time of blooming. On the other hand, up in Minnesota, some Paeonies that were not mulched were very late in coming up, after a severe winter. What was the trouble? One fall in that state I had oecasion to dig up a large clump. to transplant for a friend. The previous winter had been bare of snow, and very cold. I found that the exposed buds had all been killed. But the plants would not give up. They had absolutely formed new buds, and of course that took time. Though as far north as Manitoba they come out all right with just a snow mulching, yet it is much safer to put on a covering, because some seasons the snow may be light. When I can do so I mulch in this latitude. It is not necessary for root protection, and yet a good coat of manure pays. Many are at the trouble of using liquid manure; but if you have plenty on the ground, every rain will do the work for you, and if it is dry, irrigation will serve the same purpose. 
NON-BLOOMING PAEONIES.

The following is such a characteristic letter that I insert it here. It is a sample of the scores of inquiries that come to me along the same line:

"Mr. Harrison:- What is the matter with my Paeonies? They will not bloom. I surely paid enough for them,- - a dollar for six. I have had them five years, and only one bloom all this time, and that a little, inferior thing. I bought them for different kinds, but from the looks of the foliage I believe they are all one kind, and I guess they are afraid to bloom, because of the deception. The most aggravating thing is, my neighbor has some of the most beautiful ones I ever saw. They are loaded with the choicest flowers every season. I have had manure spaded around mine, and have mulched them in winter, with no result save great clumps of leaves. What shall I do, and what is the trouble?"

\section{ANSWER.}

"My Dear Woman:-I am afraid you have been patronizing the 'bargain counter.' If you paid only one dollar for six plants, you could not expect to get good ones. You have what you bought, a cheap lot. What will you do with them? Dig them up and throw them away. Be sure you dig deep enough to get out all the roots so you will not hear from them again. You have probably been insisting that a "piny was a piny," and that was all there was of it. Now you see your mistake. There are thoronghbreds in flowers as well 
as in cattle. A $\$ 15$ scrub cow bears no comparison with a choice, thoroughbred Jersey, which costs ten times as much.

"Think what economy there would have been in starting right. Had you bought one glorious Festiva Maxima with your dollar you would have had blooms worth while, and fifteen or twenty good roots by this time. You might have bought the beantiful l'Esperence or Andre Laures for 50 cents each, and had early and late blooms, and a wholesale lot of them. Your experience was worth all you paid for your worthless roots, and remember there are many dealers who keep just that kind of stock for just such customers. It pays to get the best. We have several that cost $\$ 2.50$ a root, wholesale, in England, and some that cost $\$ 5$ a root; but it pays."

Is it not strange, that in fitting up a home, one is so lavish on the furnishings and so parsimonious on the outside adornment? I have known a man with large and beautiful gromds and a home that cost thousands, to throw up his hands in horror at having to pay $\$ 40$ for choice trees, shrubs and flowers for the lawn. You build a costly house, and the moment you enter it, it begins to depreciate in value. You fill your yard with choice things, and they begin to increase. There is a gold mine there. Work it, and you will be rich in the beauty it gives. Don't be content with a single flower. Get masses of them.

I look out on thousands of glorious columbines, mingling their beauty; hundreds of the oriental poppies, that 
blaze in their splendor; a host of gaillardias, that are always in bloom, from June till November; and there are 5,000 phloxes vieing with each other. Why not be generous with yourself out of doors as well as in the house? If you were furnishing a new home, you would not go to a second hand store and get old rag carpets because they were cheap, and rickety chairs and other furniture, with a lot of old bedsteads.

In fixing up your front yard, why not have the best, and plenty of it? A 25 cent Paeony does not match that fine parlor set, and a lone flower or two will look cheap compared with the $\$ 50 \mathrm{rug}$. It is much better to put less in the house, and more on the outside, where it will grow in value, while the house and everything in it begins to deteriorate as soon as you enter it.

\section{CUT FLOWERS.}

More and more choice flowers are growing in favor. It is amazing how great the demand is for roses, carnations, lilies and others. The Paeony stands among the best. Properly handled, it keeps a long time. They should be cut in the evening, just as the buds begin to open. Use a long stem. Strip off the lower leaves and put the stems in water over night. They absorb moisture enongh to feed the flowers and keep them from wilting. These are carefully packed in a box and sent to their destination. If there are too many in the box and the flowers are wet they will heat in a few hours. In wet weather it is hard to get the remaining blooms and leaves dry enough to ship any distance. We have 
found the safest way is to put moss and oiled paper around bundles of twenty-five, packing them as carefully as possible, and leaving the box a little open. When the flowers reach their destination they are put in cold storage, where they are kept dormant till needed. White flowers are much used for weddings and funerals. When Mark Hanna's youngest daughter was married the house was most beautifully decorated with white Paeonies. There is a great difference in the keeping qualities of these flowers. The single ones are much admired while growing in the garden, but they are much more short-lived than the large double ones. Then there are some that grow old gracefully, like La Tulipe, Baroness and Festiva Maxima. Others are very dilapidated and ugly in their dotage. Richardson's Rubra Superba and Tecumseh are fine keepers. . So is Grandiflora Rubra. The former can be kept in cold storage a long time.

Usually the first flowers of a plant are the best. If you wait for some to bloom, and then cut the buds of those that follow, you do not get as good specimens. If you are shipping, watch them closely, and the first harvest will prove to be the best.

This is the most popular of all the flowers for Decoration Day. Some seasons they are then in their full glory. There is much call in our northern cities for those raised further south. In most of our northern states early bloomers can be secured. L'Esperence, a lovely, fragrant, French pink, is generally on time with great masses of bloom. Florists should especially draw 


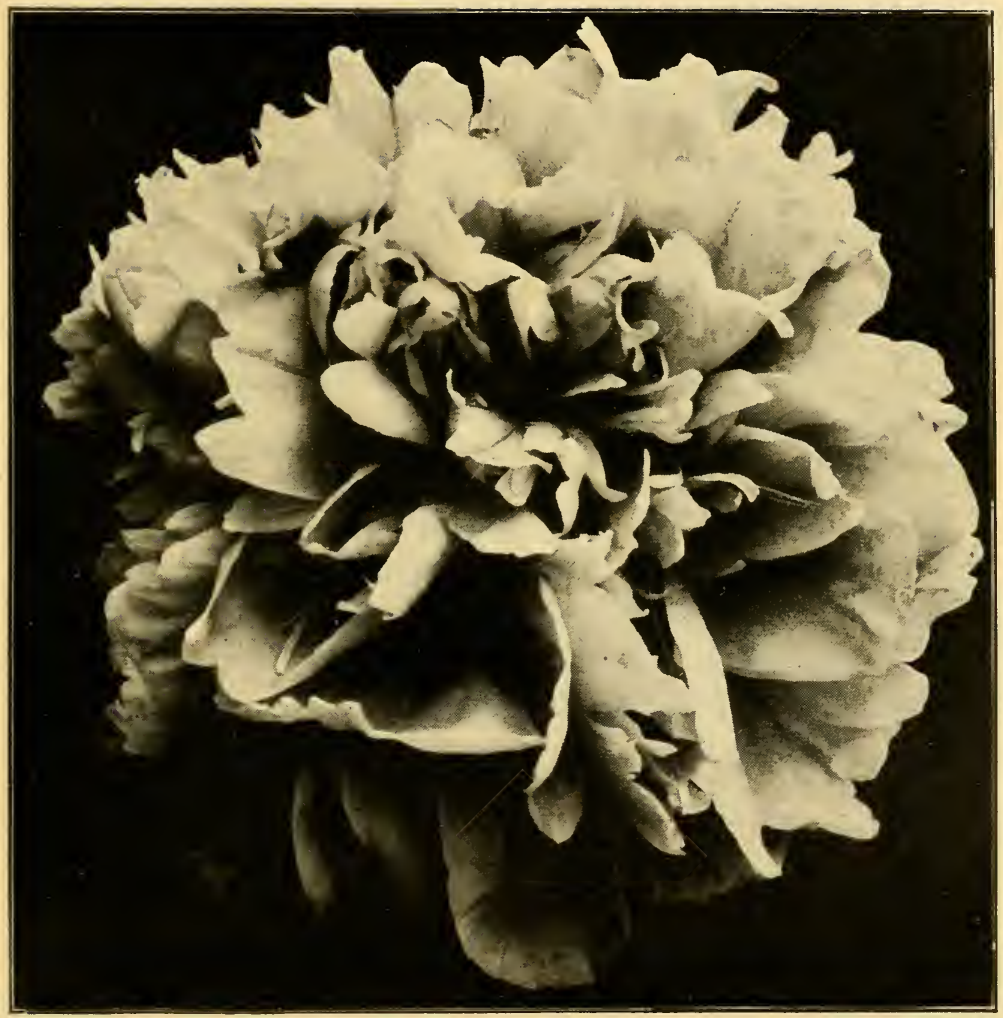

By Courtesy of W. A. Peterson, Chicago. 

the attention of their customers to these flowers for decoration, and create a demand by giving their names and characteristics. I know of one florist who secured a fine lot from Europe, but lost their names, and when he went to sell them he called them "pinys," which of course recalled the rank odor's of childhood.

Let the florist keep the finest. What rose ean put the Solftare to blush, or shame the Thorbeckii, with its cinnamon fragrance, its sumptuous beauty, grand in size, with its rich coloring varnished into its petals?

\section{CUTTING FROM NEWLY PLANTED ROOTS.}

Where you have strong roots, planted in the fall in very rich ground, on some varieties there will be quite a crop of flowers. Some growers carefully nip off all the buds the first year, thinking it will exhanst the plant. Other's will cut them close. We are to rememher, however, that it is impossible for a plant to do its hest the first season. It takes three and sometimes four years for some varieties to show what they can do. I often receive pitiful letters from ladies who are so disappointed that their Paeonies have not done better, when they had been planted but a few months. One lady, hearing this Manual was to be published, hastened to order it in the hope that it would throw some light on her trouble. Inquiring what that was, we found she had planted some Paeonies a few months before and the foliage was not as rank, or the flowers as large, as those of her neighbors. An excellent remedy in such cases is to wait. 
Beware of cutting your flower's too close. I have known plants to be killed by cutting off every flower stem with all the leaves, and others sadly injured. Don't be too greedy. Always leave some foliage to go with the plant through July and August.

\section{PAEONIES AND INSECTS.}

It is said truly that these plants have the fewest insect enemies and diseases of any of our flowers. Yet complaints come in regarding ants. These often cover' the bud, and sometimes, it is said, injure the flower. What is the reason for this? I once forced some Paeonies, and had a chance to watch them closely. I found the buds exuded small drops of purest honey. Tasting it, I could not tell the difference between it and the genuine article. After that I noticed that ants and bees and all sweet-loving insects. were very busy in blooming time. Perhaps it is not generally known that a field of Paeonies is one of the finest of all bee pastures, and for weeks the air is filled with the hum and buzz of honey gatherers. This honey is what the ants are after. They are in evidence mostly before the buds open. Sometimes they invade the flower for the nectar hidden there. The bee is busy then mixing the pollen, so that we can have a larger variety. One remedy is to have more flowers, so the insects will not concentrate on the lonely few. Those who grow them in quantities are never troubled. Another remedy is to put an old saucer at the base of your plant, with syrup mix- 
ed with a solution of arsenic. But as this is hardly fair for the bees; you had better try the first remedy.

Perhaps in time people will learn to plant in masses. Have a few choice ones; and then you can always get cheap ones that will flower, too, for $\$ 6$ to $\$ 10$ per hundred. Flowers need company. They are social things.

\section{DISEASES.}

While remarkable for robustness and health, yet sometimes when it is very wet, the foliage will rust badly. This was the ease in Nebraska in 1903. The remedy is to spray with Bordeaux Mixture. I did not do this. It is only a transient affair, and the next spring and summer I never saw more vigorous foliage.

Recently there has come to us an account of what is called the "drooping disease." A white mold forms on the diseased stem and clings to the root over winter. The remedy is to remove the stems and the earth and put fresh earth around the plant. Lime would probably be of assistance. We know nothing of this in the west.

TIIE FIVE POINTS OF EXCLLLENCE.

A first-class Pacony should be: First, symmetrical and beautiful in form; second, fragrant; third, a good keeper as a flower; fourth, a prolific and ready bloomer; fifth, the plant, to be profitable, must be vigorous, and propagate readily. We have many that score well on all these points. 
MISSION OF THE TOPS.

It is a wise provision of Nature that the tops should fall down and shelter the roots and buds in winter. They make a good covering in the absence of other mulching. If they grow in the open the snow naturally drifts in, detained by the fallen tops, and so you have a snow bank for additional protection, and also spring irrigation when the snow thaws. Yet in a visit to one of the finest Omaha cemeteries I found they mowed off the tops, to have the surface uniform, and to prevent the snow drifts, and the plants were blooming beautifully. This might do in our present cycle of wet seasons, but when years of consecutive drouth return, it would be better to leave the tops.

\section{FREAKS.}

Though generally sedate, yet this flower is sometimes erratic. I just received a severe censure from a man because his Rubra Triumphans, blooming a few months after planting, came singly instead of double. He bought of me because he thought I would be reliable, and he didn't buy any single Paeonies, and wanted the wrong righted. Now this flower, as well as many others, is ambitious to show bloom as soon as possible, and not having strength to produce a great, double flower, gives a single one. Victoria Tricolor will bloom anyway. If the root is small and out but a few months it is bound to bloom. That seems to be its mission. But it always cuts the coat according to the cloth. If 


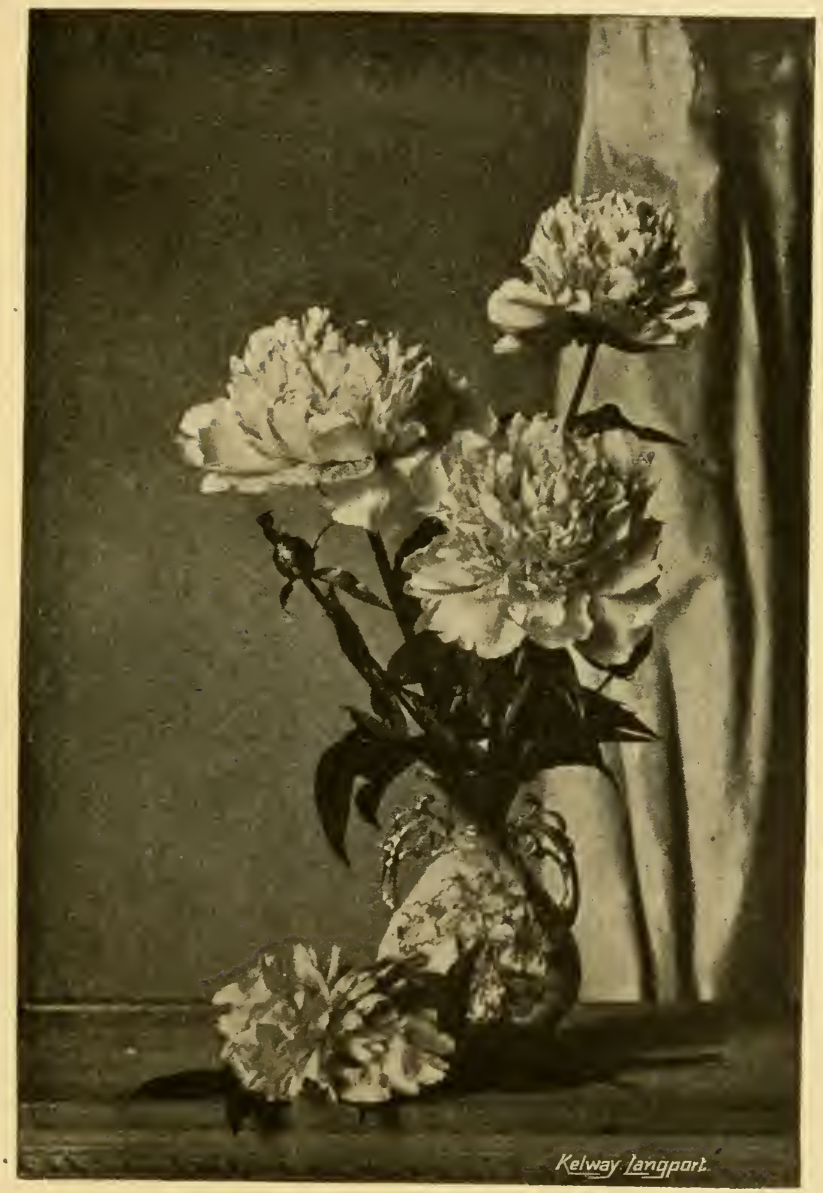

Kelway's Paeonies. 

it has material to make a great, double flower, it will gladly make it. If, however, it is short of capital, it will do the best it can. Seedlings will often bloom single for years, and then turn double. We have the record of one that blossomed single for twenty years, and then bloomed double. It is not wise to discard seedlings till. fully tested. Absolutely the finest crimson I ever saw was found in a lot of rejected seedlings. After a hard freeze in spring some flowers will refuse to bloom at all, and others, damaged in the bud, may have inferior blossoms. Others, like Floral Treasure, will do their very best after the worst abuse. Very often the last, out of season blooms of our best double ones will be little, inferior, single flowers.

Do not sit in harsh judgment on flowers at their first blooming. You can tell little about them except their color. A white one should not be red or "crimson. As to form and size, suspend judgment. There is such a confusion in names. You buy a genuine Humei, an M. Valliant and a Thorbeckii, and you have one and the same flower, yet one of our very finest. You get Bryant's Humei, Andre Taures, Fragrans, Fragrant Rose and Late Rose, and if you don't get the same thing every time, you come very near it, and all the parties honest in it, too. Our Paeony society is very busy getting the tangle out of all this confusion.

\section{WILL ANYTHING KILL PAEONIES?}

They are called hardy as paving stones and as tough as Scotch thistles. Yes, it can be done if you know 
how. Plant them in low, wet ground, where the water can stand on them, and you will succeed. Put them in wet, undrained soil. Let the snow drift on them before the ground freezes, and then it can be done. I have known some in grass and weeds during three years of consecutive drouth to be absolutely dried out and killed. It has been done by driving over them or tramping on them till the earth is like a brick bat. But they will stand all that any plant can and offer patient and quiet resistance as long as possible, and let go of life reluctantly.

The spring of 1903 gave them the hardest test I ever knew, and showed the different degrees of hardiness. April had been prematurely warm. There was a prospect of very early blooming. The stalks were some of them two feet tall and the buds were swelling rapidly. Then on the night of the 29th there came a genuine, wintry, sleet storm, and the plants in that tender condition were frozen solid in a coat of ice for two days. When they thawed out they all looked tired, drooping and water soaked; but to our surprise a few days after they stood erect and went right on with their preparation for blooming as though nothing had happened. But I noticed that some varieties on low ground took such treatment to heart. After the freeze came floods. Fifteen inches of rain fell in May. Ground usually well drained became a quagmire. Some kinds could not endure it. The Duke of Wellington could survive Waterloo, but not such treatment. Why the name of a grim, old warrior should be given to such a flower I 
cannot understand. Little, delicate Purity was too tender for such a world. Drop White dropped white, and everything else. The loss was not heavy,-just enough to show that they could be killed.

Right beside the tender ones were Ia Tulipe, Thorbeckii, Alexander Dumas, Model of Perfection, Baroness Schroder and fifty other sorts. The main plantation was in a rich, well-drained valley, but the railroad built a bridge, which proved to be a dam, and this gave way, flooding the field four feet deep. So you see what they had to go through. Sleet storm when near blooming, a flood and three terrible hail storms, and yet there was no loss of plants in that field, but a good crop of flowers.

A GOOD LIST FOR BEGINNERS.

We often receive letters asking for advice on the best kind to plant, something hardy and vigorous, that will increase rapidly and that will bloom freely. Victoria Tricolor, Reine Victoria, Victoria Modesta, Thorbeckii or Genuine Humei, l'Esperence, Edulis Superba, Rubra Triumphans, James Vick, Andre Laures, Late Rose, Grandiflora Alba, Compte de Nantuel. These should be had at quite reasonable rates; good, strong roots. One need not be entirely confined to this list There may be an abundance of others as good.

WIAT OF THE FUTURE IN PAEONY GROWING ?

Evidently the cheaper sorts will remain at about the same price, for the number will be swelled by rejected 
new ones. The standard varieties will remain about as they are, with a slight advance. The new or rare sorts of especial merit will keep up at the present high rate, or even advance, for thousands of people will be found who will have the very best, and the high priced ones will be as sure an investment as a poor man can make. An invalid lady can engage with success in this industry. If you go into carnations or roses you will need costly green houses. If you wish to raise Paeonies, which will be just as profitable, the directions in this book will give you just as good a chance as the millionaire has. There is probably no industry so inportant and profitable that can be carried on with such little expense as this. You may be poor, with only a little home and a small garden. You have a baby girl, and you look forward to the time when she will enter on womanhood, and shudder as you think she will have nothing with which to begin life. Buy a genuine Baroness Schroder, or Lady Alexander Duff, or Marguerite Gerard; one good, strong root, and let it grow, and take care of it. One thousand in ten years. How many in twenty years? A thousand multiplied by a thousand. You would in fifteen years have enough to retire on. This is not comnting chickens before they are hatched. There are no broken or addled eggs among them, and they will grow for the poor man as well as the rich. "The business may be overdone in twenty years;" then all the flower business will be done for, and there will be no more call for carnations or roses. Festiva Maxima for more than half a cen- 
tury has been on the market, and the market is hungry yet, and will be. If you are a young man and have a little ground, and want to insure your life, buy a Pacony, the best you can hear of, or take what you would require for your first payment and purchase several, and they will take as good care of you as the insurance companies could. These companies live on lapses, and those securities don't lapse. Should you die, you are sure of what you paid in, with compound growth, which means compound interest.

The English say this is the flower for the "millions and the millionaire." I think they would grow better" for the poor man than for the rich, for he would regard his bed of choice plants as his gold mine, and would take the best of care of it. It takes years to learn a trade and learn it well, a trade that will lay up money for old age. It takes a good deal of cash to go into business which will bring in adequate returns. But it takes but little time, or cash either, to get a few of these choice plants, and then love them and care for them. A little capital invested in this way can be kept sacred for the future, and insure comfort in old age. There are no doubtful and uncertain board of trade complications about the business. Set a little aside, and how much incidental enjoyment you would reap from it. Those worshipful flowers in queenly garments saluting you, and they are all your own, and their numbers increasing as the years go by; an income from the 
blossoms and a greater income in the way of princely enjoyment. And though poor and hard working, your flowers will treat you as well as if you were rolling in wealth, swelling with pride and riding in an automobile. 


\section{CHAPTER XVII.}

\section{A LIST OF SOME OF THE LEADING SORTS.}

In giving this list we have aimed to give some out of the 2,000 named, so the reader can have an idea of the marvelous variety in this great family. The fragrant ones have not all been marked fragrant. We have not always given the names of the originators. Most of these we have tested ourselves; others we have taken from leading French, English and American catalogues.

It may not be satisfactory to the connoiseur-probably will not. The idea of this book is to introduce this flower to the masses.

I confess we have given some prominence to western productions, because their merits have not hitherto been brought to light. Raising them for years, side by side with imported ones, we feel they should have a fuller recognition. All honor to Father Terry, now 78 year's old, who, in a quiet, patient way, for over 30 years, has been hard at work, giving us the best results of his persistence and skill, from which, as yet, he has reaped but little benefit.

DESCRIPTION OF OVER 200 CIIOICE KINDS.

Admiral Dewey-Guard petals deep rose, with center of pink and cream. 
Alice-Blush rose, changing to white, center with straw shadings; fine flower.

Agnese Mary Kelway-Guard petals of light rose, yellow petaloids.

Andre Laures-Perfect rose in form and fragrance. Alba Sulphurea-Fine white with sulphur center.

Alexander Dumas-Mixed pink, double center, very double, quite fragrant. This is every way satisfactory, scoring the fine points readily.

Baroness Schroder-In England this is called fleshcolored; in Massachusetts it is sometimes grayish white; in Nebraska it is the purest, softest white. In the central petals there is the faintest lingering of golden tints. It is as sweet as the rose, and in form and grace of outline surpasses any of the rose family. Withal, it is so fluffy, sprite-like and ethereal, it seems as if it might float away. It is vigorous, and a ready bloomer. After it had grown two years I cut one root into eight, and six of these bloomed the next spring. They are very scarce, and spurious kinds are put on the market. This exquisitely beautiful flower scores the five points easily.

Beauty's Queen-Is a large white; outer petals blush rose.

Bunch of Perfume-Full double, vivid rose, very sweetly scented. This does not do as well in the west, probably, as in England.

Bioni-Guard petals light blush, with thread-like petals; not as vigorous as we could wish, though a lovely flower. 
Bicolor-Outer petals white, with rose tinge; cream center, fringed; crimson blotch on center petals.

Belle Hough-Large flower, light crimson, late and fine.

Bertha-Brilliant crimson, full double and late; a very satisfactory flower.

Belle of Crescent-Bright rose, free bloomer, large double, very showy.

Belle of York-Large, flesh-colored, a strong, robust flower, new.

Baron James de Rothschild-Semi-double pink.

Bridesmaid-Fine, semi-double, fragrant, white.

Blushing Maid-One of Rosenfield's latest, fine blush and sweetly perfumed; not yet fully tested.

Canisto-A large lovely flower, light flesh in color, fading to white; fragrant.

Carnation-Bright crimson outside petals, broad inside finely fringed, very fine. Grand, late bloomer. Very striking in appearance.

Clara Barton-This is one of the earliest. It is of purest white, like the spirit of its namesake. Its petals are delicate and almost transparent in their tissue-like form, not quite full double, but exceedingly attractive.

Crimson Queen-Both petals and petaloids are of the same deep color. It is finely fringed, but the whole flower is of that solid, intense coloring.

Commodore Dewey-Is deep, dark rose, of intense color. It is a large and attractive flower, one of our finest new ones. 
Col. Wilder-Is bright rose, very double, blooming in clusters.

Compte de Paris-A vigorous and imposing plant. Flower on strong stem. Guard petals pink. Yellow senter. A mingling of pink, cream and gold with a dash of red.

Charlemange - Very large flowers, double, flesh white center, tinted lilac and chamois. This does not always sustain its reputation, being: apparently sensitive to soil and climate.

Compte de Nantuil-Blush white, center tinged yellow. Having tested this for years I can commend it for beauty of bloom and vigor of plant.

Chrysanthemefolia-Rosy white guards, with a delicate chrysanthemum folded in the center.

Comptesse de Montalivet-Flesh, fading to white. Fragrant.

Cardinal Richelieu-Solid red, no stamens, large guard, very fragrant.

Carnea Elegans-Large, variegated pink, rather light color, with rose guard petals. A strong plant.

Duke of Devonshire-A very large flower of striking appearance, crimson in color, with satiny finish. One of Kelway's best.

Delicatissime-Very beautiful, light brilliant crimson.

Duc de Wellington-Soft white, with pale, creamy white center. Very lovely, fine form. Plant not strong and vigorous.

Delacheii-Fine, dark crimson. 
Drop White-Pure white, splashed with crimson, fragrant and full double.

Double Decker-Is a fragrant and beautiful twostory flower, named Pallas by Terry, the originator. First it appears single; in a day or two another blossom sits in the lap of the first-a charming and unique flower.

Duchess of Orleans--Pale rose, with salmon center. Defiance-Brilliant crimson, tall and fine. Single. Dr. Lindley-Large flower, tall and strong. Dark crimson.

Ella Adams--Light crimson. Very attractive.

Etta-Bright, satiny, light rose. Strong grower, late bloomer.

Euphemia-Flesh colored, with erimson blotches.

Excelsior-Dark crimson, large, fine, symmetrical flower, very striking in appearance.

Esther-Outside petals deep rose, inside white, rose tinted, a full bloomer.

Edulis Superba-One of the standard varieties. Shell pink, large, well formed, fragrant flower, and a very rapid multiplier.

Emperor of Russia-A magnificent, leep crimson. Very handsome.

Edulis Plena, or Albiflora Plena-White.

Eclatante-Is deep rose.

Fragrans-There are three that bear this name, one named by Kelway, a light purple; another is solid pink, with rather full petaloids, all the same color, and 
yet another, which is the late rose Paeony, nearly, if not quite, identical with Andre Laures.

Francoise Ortegal-A striking French crimson. One of the popular old sorts.

Fulgida-Is another purplish crimson.

Formosa Alba-White, with cream center. Very fragrant, and one of our fine ones.

Faust-Is rosy white, large and full double. An exceedingly attractive flower.

Festiva Maxima-Is the queen of all. Almost without exception it is placed at the head of the list. It has every point of excellence. The plant is one of the most robust. You can usually tell the genuine by the shape of the large leaves. This, we understand, was introduced from Belgium in 1835, and all this time it has been propagated, and it is impossible to supply the demand. The Joliet Paeony farm, one of the largest in the world, wholesales them at $\$ 1.00$ each, or $\$ 60$ per 100. I am informed that the flowers bring $\$ 2.00$ per dozen, wholesale, in Chicago. The flower combines great size with wondrous beauty. I have raised them seven inches across, a glorious form of purest white, flecked here and there with crimson, which seems to bring out the white in clearer relief. This flower seems to have reached the ultimate, beyond which we cannot go. It is so full double it seldom, if ever, produces seed. Nature, all along the line seems intent on reproduction, but in a case like this she seems to say, "I can go no further." This is a good pattern to work by. Feed this grand flower. Let it do its best. And the 
resplendent form of beauty secms to say, "Beat this if you can." Men have tricd for seventy years, yet we will keep on trying.

Festiva-Is fragrant, pure white, globular in form. A beautiful flower.

Floral Treasure-This is one of Rosenfield's, and it reveals the fact that we need not always go to Europe for choice ones. It was first put on the market for $\$ 12.00$ per 100 , but as soon as people found out its merits it shot up to $\$ 50.00$ per 100 , and the supply was short. It is a splendid hemisphere of fragrant loveliness, a good keeper, and has a long, strong stem to uphold the splendid bloom, which will sometimes be nearly seren inches across.

Fairy Queen-Is one of Terry's. Outside petals broad, inside fringed, full double, large flower, regarded by Mr. Terry as one of his best.

Fragrantissime-Beautiful white; very fragrant.

Grandure-A very fine, large, semidouble lilac rose, fragrant. We have had this several years. It has peculiar tints and shadings, which add materially to the attractions of a general collection.

Grizzel Muir-This is among Kelway's best. Pure white, good form and very fragrant. We are well pleased with it.

Grandiflora-There are several wearing this name, of different colors. The most striking among them is a late, immense, full double flower, blush in color, very solid and compact, with a stem not strong enough to hold the immense weight of beauty. These should be 
planted in a mass and should be sheltered with a screen from the burning sun. This is probably one of Richardson's

Glori de Doual-Deep crimson, semi-double.

General Jacqueminot-Color like the Jack Rose. Large flower, fragrant and a good keeper.

General Grant-One of Terry's fine ones. An immense flower of dazzling red. The only trouble is it does not furnish stem strong enough for the flower.

General Sherman-Another of Terry's. A strong, vigorous grower, rose color, tinged with purple: Late bloomer.

Grover Cleveland (Tecumseh)-This in another of Terry's. It is a little freaky. One year it was described as follows: "It is a system of deep colored, rich flowers, packed and pressed together into a shapely ball of dazzling red, the solidest of all. You could almost stone a dog with it. It is one of the best keepers we have." Cut while the bud is opening, it retains its beauty a long time. Sometimes it is more open in form, but always a splendid flower. Another season it will open with a broader bloom, but whatever form it assumes, it is fine.

Grandiflora Carnea Plena-This is one of our best, and hard to describe. It has pink guard petals, with a mingling of many tints in the center. It is fragrant; globular and compact in form. It gives a long sucession of bloom, and the flowers are fine keepers. The early ones grow lighter with age, and new ones come on, clothed in their showy tints, so that a single row gives 
such a variety of shadings that one might think there were several kinds in one fine blend of loveliness.

Golden Harvest-Rosenfield's. The more you see of this the better you like it. It is a free bloomer. You can depend on flowers the first spring after planting, even in six weeks after spring planting. At that stage of development it shows a center of pure gold. The next year it shows the same, only more. In the center is a miniature, snowy white flower, like a condensed Festiva Maxima, with dashes of carmine. The next year the whole plant seems to break from all antecedents and give you a wild, rollicking prodigality of beauty, in blush and white, in cream and gold. The flowers are large and almost smother the plant, so great is their profusion. The bloom may not keep as long as some others, yet it will score all the points, as it is very fragrant withal. This and Floral Treasure are Rosenfield's advance guard. He has fifty to one hundred more in the procession, and we can take off our hats as they pass by and cheer for beauty and Nebraska.

Golden Wedding-We have long been looking for a pure golden flower, and here we have it. It is fragrant, semi-double, with extremely delicate bloom, and a very attractive flower. It is a very vigorous plant. Singles and semi-doubles do not keep as long as full doubles. This is the only drawback to this lovely flower.

General Cavignac- Very fragrant, rose pink, of solid color, compact head, imbricated with a deeper shade, like a carnation.

General Lawton (Pleas)-Bright rose pink, edged 
with white, often triple headed, which gives it a massive appearance. It is very robust, flowers large and slightly fragrant.

Globosa Grandiflora-Large, globe-shaped, white and very fragrant.

Grandiflora Rosea-Is a host in itself. The outer and center petals are red. It is slightly fragrant. It is a very prolific bloomer, robust and vigorous. The flowers turn lighter in a few days, and remain on the stem a long time. Looking at the bed you would say there were several kinds. In this respect it is much like the "Seven Sisters" among the roses.

Grandiflora Alba-There are several kinds that bear this name, but the best is a strong, vigorous plant, with a good stem, and a large, fragrant flower. Pink guard petals, sulphur center, splashed often with crimson, the whole changing to snowy white in a short time. It is a good keeper and a prolific bloomer. These have been sold by the thousands, innocently too, by some of the best firms, for Festiva Maxima, which in full bloom they closely resemble.

IIumea Alba-A very fine and rare variety. It has the beautiful blush of the morning. The guard petals are light pink. The center has a thread like collar of light flesh petals. It has a delicious fragrance. There are two Paeonies which bear this name.

Humei Carnea-There has been an infinite amount of confusion regarding this Paeony. At least six kinds have been sent out under this name. Many of our lead- 
ing growers are at fault, and some writers also. Andre Laures has been sent out for it, and other varieties entirely at variance, and a recent work on Bulbs is at fault. Yet it is one of the most distinct types of all. It has a foliage peculiar to itself. The color is a rose pink. The petals look as if the color was varnisher into them. It is a large, compact, solid, glorious flower, of symmetrical form and cinnamon scenter. It ranks among the best, and scores the full five points. This is often confounded with the large M. Yalliant. It should probably be ealled Thorbeckii.

Halseus-Is a French white. It first opens with a pinkish flush, gradually growing lighter.

Hesperides-Is white, with flesh guard petals.

Henry Demay-Is a striking and beautiful flower. Light crimson, fine form and symmetrical.

Hercules-Terry's. Is tall, light rose, tipped white. Herman-Terry's. Is a tall, strong grower. Petals broad. Pale, purplish rose, inside straw-tinted.

Irma-Soft rose, flesh tinted. I secured this from France, and am well pleased with it.

Ilion-Has white guard petals, and also narrow white center ones.

Insignis-Described in French catalogue as a grand flower, of brilliant carmine.

Jeanne d'Are-Had a slight mention in former bulletin. We now hasten to do her justice. Some plants do best when the stools have had three or four years in which to become established. 'Then they burst forth in a very splendor of loveliness. Thus did our Jeanne. 
The flower opens light pink, but gradually grows white as the soul of the war maiden. The center of the flower rises like a crown, and the pure whiteness seems sprinkled with drops of blood, symbolic of the cruel death she suffered. It was a delight to visit those fragrant and lovely flowers and linger over them and drink in their sweetness.

Jennie Lind-Has suddenly sprung into prominence and value. Clear, rose pink, long stem, fragrant and good keeper.

Jugurtha-Is a dwarf, ,bright pink.

James Kelway-Very fine, white, beautifully scented.

Joan Seaton-Double, bright cherry rose, each petal edged with lighter color. A rose-shaped flower, showing anthers among the petals.

Juno-Is fiery, flashing crimson.

Jupiter-Is large, full double crimson, tipped light. Kelway's Queen-Light pink, a most delicate and lovely sort. Very fragrant.

Kitty Green-Rosy lavender, large flower. Fragrant.

La Reine-Terry's. Delicate blush, changing to snowy white. Center light yellow, sometimes touched with crimson. We are well pleased with this fine, fragrant flower.

Lucretia-Light blush, good size, shapely, with a sort of twilight lingering in its petals.

Lady Curzon-We are favorably impressed with this flower. White guard petals, with cream colored inner 
petals, a faint blush permeating the whole flower at first. It is of good size, and delicately perfumed. Every way worthy of the lady whose name it bears.

Lady Alexander Duff-This flower has been spoken of as the very queen of the whole family. It is described by Kelway as lovely French white. One of the grandest in existence; tall, robust and highly perfumed. The roots of this flower are worth $\$ 10$ each and hard to get at that.

Lady Bramwell-Is silvery rose. A most charming flower, perfect in form, compact, symmetrical and exceedingly fragrant. It is one of our fine ones. It wears well on a long acquaintance. There are hardly enoug? to keep up with the demand.

Lady Beresford-Described as a large-flowered variety of soft lush shade, delicate and beantiful. The petals are tipped in carmine. I sent for two of these. One was an inferior, little, single one, and the other a small pink.

Lyde-Is rose color, with pink center.

La Coquette-Is on the diamond list of Paillet, of France. Center and guard petals pink, balance salmon. A fine, large flower and a good keeper.

La Tulipe-I know of no flower so attractive in the bud as this. First a ball interlaced with green, red and light. As it grows, these interlacings are more pronounced. There is no bloom whose unfoldings you watch with greater interest. Men, women and children gather around it in delight. Finally it opens, a solid ball of softest blush, with streaks of carmine. There it 
sits in all its beanty, a glorious flower in a chalice of veined marble, emitting a delightful perfume. Gradually it fades to purest white, looking much like Festiva Maxima. It is a splendid keeper and scores the five points to perfection.

L'Esperence-Said to be almost, if not quite, identical with Duchess de Nemours. This is an excellent variety. In the first place it is a pink rose in form and fragrance. It is especially valuable in the northern states, as it is a strong, hardy and robust plant, and often is on time for Decoration Day. It is a good keeper. It is on the diamond list of the leading French dealers. It scores the five points.

Limosel-Very bright, clear lilac rose. A large flower, full double, with broad guard petals and narrower ones in the center. Very fragrant. Having had these for several years they stand up well to the description.

Lonis Van IIoutie-Is a splendid, rich crimson, a magnificent bloomer. It stands well at the front.

Morning Star-Is one of the most dainty of the whole family. Though exceedingly delicate looking, the plant is hardy. It is well named. Starry rays radiate from its heart of gold.

Mrs. Fletcher--Terry's. Is an attractive flower of deep, dark rose color. We have found it very fine.

Mrs. Rudd-Outside petals broad and white, inside straw color, petals finely fringed.

Nigra-Is one of the rarkest crimson, full double.

Marie Crousse-Very large, full, globular bloom; 
soft salmon pink, shaded with glossy lilac, very fresh color.

Marie Stuart-Beautiful anemone-shaped flower, with collar of bright clear, pink petals; center sulphur white.

Madam Chaumy-Is a large, symmetrical, solid pink flower, fragrant and very charming. In form and color much like Lady Bramwell, only it is much later and larger.

Mme. Camille Bancel-Described by Ward: Very full, enormous, globular flower, color lively blush lilac pink, with center shaded with salmon.

Madam Geissler-Is light purplish rose, solid color, massive and very fragrant. One of Mr. Peterson's favorites.

Margnerite Gerard-Deseribed by Ward: Immense flower, with very large, well formed petals; color clear flesh, fading to tender, creamy white. Center creamy white, with petals oceasionally spotted and tipped with earmine. Ward \& Shaylor place this high on the list. It is one of the more recent French productions.

Modeste Guerin-Large, anemone-shaped flower; color uniform, bright carmine. Very attractive, standing well up on the list.

Mons. Jules Elie-Described by Ward: Very large, full, globular flower, with broad, imbricated petalage. Color glossy pink, deepening at the base of the petals; reflex silvery pink; flower of nice form, and quite fragrant. 
Mons. Paillet-Probably named from the noted French florist. It is a very large flower, light pink, shading to white, with pond lily fragrance.

Mons. Rousselon-Guard petals are rosy pink, center petals the same color with delicate shadings, slightly flaked with carmine - a very distinct and beautiful flower.

Madam d'Vernville-Father Terry goes into raptures over this flower. It is well at the head in merit. Described by Thurlow as a very valuable new Paeony; globular form; white center petals tipped with carmine; very fragrant, vigorous and floriferous. I was happy in securing a quantity of these and shall watch them with intense interest.

Model de Perfection-Described by Peterson: Far superior to the sort generally sold under this name. A solid, clear pink, with crimpled center, set on large guard petals, forming immense globular buds and flowers on strong stems. Years ago we secured some of these from Mr. Peterson. They are eminently satisfactory. Hardy, full bloomers, fragrant and good keepers. Marie Lemoine-The Lemoines are noted florists, but their names are a little too numerous. We have several among the Lilacs, also among the Philadelphus, and here the name is stretched to cover two entirely distinct varieties. One fathered by Calot is lovely, ivory white, an early bloomer, emitting a delicious fragrance, with a root tangled and twisted, and hard to separate. The other, fostered by Crousse, has a large, full double bloom; color sulphur white; center petals 
lightly edged with pink. Very late and one of the very best.

Madam Breon-There are two flowers bearing this name. One, outer petals rosy pink; pale yellow center, changing to white; and the other is fine, shapely, solid crimson. This latter was sent out by T. C. Thurlow.

Magnifica-Described by Kelway as delicate pink, turning to blush white; large, full and free. That usually sent under this name is nearer red, turning to pink.

Magnificent-Is a medium sized flower and fragrant. It is of the pink, cream and gold order, with drops of carmine. Much like Triumph de Paris, only smaller.

Madonna-Outer petals rose, center creamy chamois.

Moonbeam-Is one of Kelway's newer ones. Large, white, tufted in the center.

Mme. Schmidt-One of Paillet's; is rosy, lightly tinted white, large flower; does well in Nebraska.

Marie-Is white, in light rose tints.

Maxima-Is white, with short petals.

Nymph-New. It opens a single flower, with white petals. It has a pond lily fragrance. In the center are incurved snow-white petals and these are dotted with crimson, making it a most attractive flower. Later, the inner petals expand, forming another perfect flower sitting in the lap of the first, separated by several rows of stamens. It continues in bloom a long time, and it is a delight to watch its varying forms of loveliness. 
Noblissima-Is a fine flower of rosy lilac; very attractive.

Ne Plus Ultra-Is a fine flower, peach-color, edged with white.

Nivalis-Is pure white.

Princess Ellen-Opens delicate flesh, changing to white; large flower and a good keeper; very desirable.

-Princess of Wales-Terry's. Large, white, mottled with rose; a fine flower.

Prince of Wales-Terry's. Purple, edged silver, large, full double, often in clusters.

Prince of Wales-Kelway. Soft lilac rose; large flower, rather shy bloomer.

Princess Beatrice-Pink guard petals, inner petals yellow and pink; a fine variety and free bloomer.

Peter the Great-Is deep, rosy purple. Sunburns badly in Nebraska; needs shelter.

Plutarch-A satin crimson, exceedingly brilliant and striking, with pond lily fragrance; a very choice flower.

Pulcherima-Light, satiny rose, center blush white.

Pulcherima Odorata-Shaded pink, with yellow center, and fragrant; very fine.

Pottsi-Purple crimson, with thread-like petals; a very conspicuous flower and in great demand.

Pomponia-Fine large, flesh colored blossom fading to white.

Queen Victoria-There are three distinct flowers which seem to be wearing this name. One that has been raised by Terry for 40 years is described by him dark 
rose with lighter edges, center straw color, large flowers. Kelway describes his as flesh colored, large, compact center, and red blotch in the central petal-a grand flowr.: The other in most common use is identical with the Whitleyi, which is blush white with cream center.

Red Jacket-As several deep crimson, new Paeonies have come into the writer's possession, he has named them after Indian chiefs. One is King Philip, a tall, robust plant; one is Red Cloud; one named Shabona; an extremely fine one is Pocahontas; and a dainty little single is called Pappoose. Red Jacket is a finely formed flower, deep rich color and very fragrant, which is a little unusual in deep crimson. I think it much surpasses both in form and fragrance the new Bunch of Perfume. The only drawback is it may be a tardy bearer.

Rubra Triumphans-This is the earliest of the crimson family. It is not quite full double. It has a golden center. It is valuable in that it is often on hand for Decoration Day.

Richardson's Rubra Superba-This is one of the grandest of the whole race. It is very robust and of immense size; as Peterson says, one of the finest that ever happened. It is among the very latest, deep crimson in color, of immense size and firm form. It is very valuable as a cut flower. Taken just as the buds swell and put in cold storage it will keep for a long time.

Richardson's Dorchester-Is another very fine one, beautiful, soft cream color, with pink tinting, rather 
dwarf. A beautiful flower. This was taken to England and appears in Kelway's list as a $\$ 2$ flower.

Sunbeam-New ; fragrant; radiant silver, ethereally beautiful; very striking.

Sainfoin-Kelway. Described as the most striking of all. The flowers full, large and brilliant self rose.

Snowy Coles-Blush white, with narrow, thread-like petals; very sweet.

Souvenir de la Exposition-Blush outside petals, with white, narrow central petals. A fine, large, imposing blossom.

Splendida-Light lilac, edged white.

Sada Evans-T'erry's. Outside petals broad, delicate rose, inside fringed and straw-colored, the whole melting into a beautiful white.

Stephania-Considered by Terry as one of his finest. Pale rose, nearly white; center pure white with crimson stripes.

The Bride-Is a charming white flower.

Thomas Meehan-'Terry's. Light rose, silver tipped; large double flower, worthy of the noble man whose name it bears.

The Amazon-New. If you wish size and show and a good deal of it, this is the flower. There is nothing: refined or delicate about it. It is exceedingly prolific and robust, and bears an enormous burden of great, rose colored flowers. It is full, free, hearty and generous, and a good one for beginners.

Victor-Terry's. Deep red; a fine, fragrant, solid flower, and a good keeper. Very desirable. 


\section{Virgo Maria-Pure, snowy white.}

Victoria Tricolor-Is one of the most vigorous and prolific bloomers we have. The first year it will put out small blooms, according to the material it has. The next year they will be larger, and the third year the plant will be fairly deluged with bloom. It is also fragrant. Though the flower cannot rank among the finest, yet it is very desirable.

Victoria Modesta-Is a very fragrant flower, borne on a long, strong stem; outer petals pink, inner ones white.

Reine Victoria-Is a fragrant pink. These three Victorias, while not ranking among the very best, yet on account of their fragrance and vigor should not be omitted.

Zoe Callot-Is Grandiflora Rosea on a smaller scale.

Grandiflora Rosea. A fine flower with light pink outer and inner petals.

Zenobia-Is one of Terry's. A full double rosy crimsoll.

Zonvon-Is a deep, dark, bright flower from Holland.

SINGLE PAEONIES.

These are very beautiful in the bed, but not so desirable as cut flowers. They are not as long-lived, and have a tendency to fold their petals at night, yet some of them are of marvelous beauty. They are not as popular in the west as in the east. I name a few of the leading ones from Kelway's list: 
Bridesmaid. Single white.

Captain Holford. Clear rose.

Countess Cadogan. Lovely flesh color.

Countess of Warwick. Delicate, soft flesh.

Doris. Bright rose.

Duchess of Sutherland. Large, flesh pink; a lovely flower.

Earl of Morley. Light purple.

Earl of Powis. Cherry rose.

Earl of Onslow. A good purple.

Flag of Truce. Pure white.

Flag' of War. Deep, blood crimson.

Ideality. Deep rose; grand.

Kimberly. A very pretty, rosy pink.

Lady Helen Vincent. White; tinged flesh; very beautiful.

Lady Jemne. Blush white; very delicate.

Lord Annaly. Deep crimson; a fine, rich shade.

Meteor. Bright, dazzling crimson.

Other single ones of American birth:

Defiance. Terry. Brilliant crimson; tall and fine.

Full Moon. New. This is one of the most striking, immense crimson, with strong outer petals and a full moon of golden stamens. A hearty, open-faced flower.

Terry. Is a sort of lilac rose, very rich color.

St. Sophia. Terry's. Is deep rose, and has the longest succession of bloom of any of the single family.

Wild Rose. Pleas. Is a fine, open-faced crimson flower, with a large, golden cushion.

May Davidson. Is a large pink, stripeå with silver. 
The Queen. Terry's. Large white, with cushion of pure gold.

We have several others on the way, whose merits are not fully established.

\section{THE JAPANESE PAEONIES.}

These are a distinct family by themselves, single and semi-double, with very pronounced golden centers. They are prodigal bloomers, often covered with a profusion of beauty. They are very hardy. Some of us are endeavoring to raise a new race from seed, and here there is a vast field. The nomenclature of this whole family is in a chaotic state, and the Paeony Society is hard at work naming and classifying them. I have in all some thirty kinds. I append Henry Dreers' list:

Apollo. Deep pink, shading lighter toward the edges.

Diana. Blush, with creamy white center.

Exquisite. White, with yellow stamens.

Fabiola. Delicate blush.

Neptune. A fine shell pink.

Ophir. Dark carmine.

Saturn. Rosy pink, with yellow stamens.

Souvenir. Flesh pink, creamy white center.

Titian. Soft, delicate pink.

Vesta. Purplish red.

Topaz. Deep rose, shading lighter at the margin.

Undine. Bright pink, with darker shading. 


\section{CHAP'TER XIX.}

\section{GLADIOLUS, THE SWORD LILY.}

The diminutive of "gladus," the sword. The meaning is "little sword."

There are about 90 varieties of this beautiful flower. They are found growing in the region of the Mediterranean, in Asia and most of the species are from South Africa. Marvelous improvements have been made in recent years in this flower. Blossoms of immense size have been produced and these are of great beauty.

It is true the bulbs must be planted every spring and must be taken up every fall. Yet, there is no hurry in the spring. These with dahlias and cannas are planted after the rush of spring work is over.

\section{SOILS.}

Our Western rich prairie loam is just the thing for them. Some people stake the stems. As a general thing this is not necessary if properly planted. The soil should be heavily manured the year before so the manure will be well incorporated and the ground fine and friable. Then plant at least 4 inches deep. When I first commenced I had a good deal of trouble with the long heavy stems tipping over. I found the trouble 


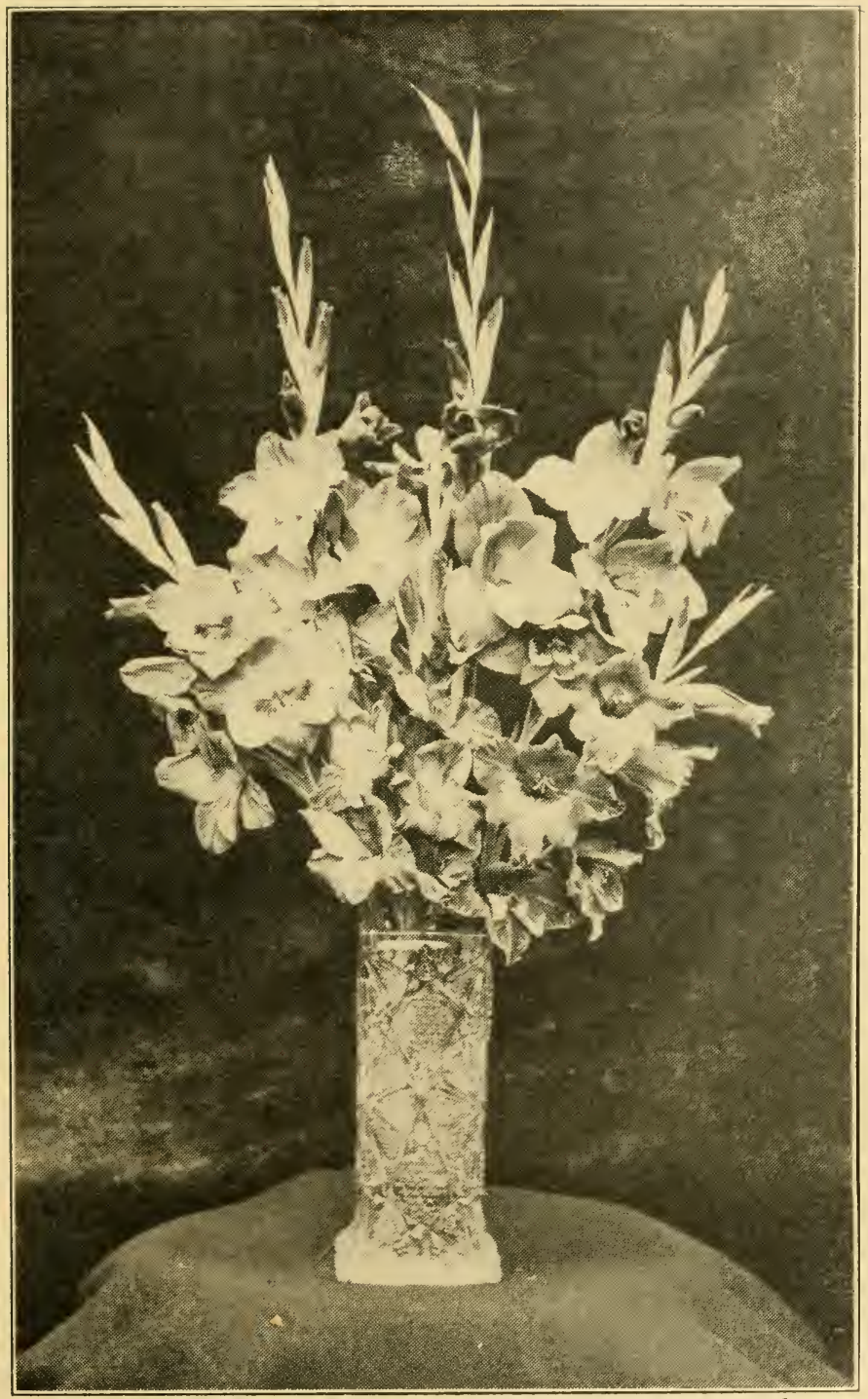

Presented by Arthur Cowef, Berlin, N. Y. 

was I had not planted deep enough. You can have your rows about two feet apart and put them four inches apart in the row. They need thorough cultivation. When they first come up, before they are very high, go over the whole ground with the rake. That lightens the soil and kills the weeds while the plants are set deep enough so they are not disturbed by the rake. Never grow anything in partnership with weeds. Irrigate with the hoe and eultivator. More and more we are finding out that constant cultivation is absolutely essential to suceess. This keeps the ground from drying out and kills the weeds. Cultivate after erery rain if possible. This closes the pores in the soil and retains the moisture.

\section{PROPAGATION.}

It is easy to raise them from seed and then you have the charm of discovery. You are sure of something new. Save seed from your best plants, prepare a bed thoroughly, put the seed in shallow drills and cover about an inch deep. See that they do not dry out in germinating. If in the open it is well to cover them with burlap till they begin to come up. In the fall dig and dry them and store in a dry cellar. Plant again the next spring and they will be large enough to bloom the year following.

Do not plant on the same ground in succession. Choose a fresh place each year.

When you take up the bulbs in the fall you will find rows of tiny bulblets attached to them. Sometimes 
there will be from one to two hundred of these tiny corms attached to a single bulb. You take these off and plant them as you would peas the next spring. Of cour'se these will be like the parent root, while the seedlings will give you something new.

We are often asked if paeonies, dahlias, cannas and other flowers will not mix and change color by being planted near together. Never. This is impossible. The seeds will of course bring different results, but merely growing side by side will never effect any change.

\section{THE FLOWERS.}

While in Minneapolis in the summer of 1904 the florists told me there was no sale for the flowers and they went begging everywhere. Looking at the blossoms I did not wonder, for they were little, out-of-date affairs. Not much like the grand, full, radiant ones of more modern types.

The Childs \& Groff's hybrids and Burbanks outrank the old sorts and by constantly selecting seed from the best there is a chance for great improvement yet.

When the first flowers begin to open, cut off the stem and put it in water and it will keep on blooming a long time.

There is an almost infinite number of named sorts.

Arthur Cowee of Berlin, N. Y., is quite a specialist in this line and sends out a very neat little booklet with various approved varieties and directions for obtaining the best results. He has immense fields of them and seems to keep at the front. 


\section{SUCCESSION OF BLOON.}

This can be regulated both by varieties and also by the time of planting. In a bed of several hundred some will bloom very early and others late. I have had them bloom in November while others of the same planting will blossom early in July. For a succession plant about the first of May. Plant another lot the first of June and you can plant again in July. In fact late blossoms are the best because they come on after the intense heat of summer has passed. If you wish the best results while they are blooming in the hottest part of the season and it is very dry, shelter them with burlap or muslin.

FORCING THEM.

Having had no experience in this line I quote from an expert, C. L. Allen, of Floral Park, N. Y.: "The gladiolus for decorative purposes during the winter season has of late been considerably used; many growers having been very successful in bringing it in at the proper time, making it a profitable branch of their industry. This had the tendency to induce others who had not sufficient knowledge of its requirements to make a success of the enterprise, to plant on a large scale. Like all other undertakings, with hope, rather than experience as a guide, it has not been as profitable as might be desired." But a few men have been successful, among them John Thorp of Peal River, N. Y., who knows the gladiolus well and acts accordingly. 
The flowers he produced reach the full measure of their capabilities. We quote what he says:

"The gladiolus when grown as a forced flower is appreciated to a greater extent than when grown out of doors. Like many other flowers it is better under the protection of glass. When well cared for the flowers are larger, the colors purer, and the spikes longer. To force them successfully, however, requires attention at just the right time, and its wants should always be anticipated and supplied. Here is the routine of $\mathrm{my}$ practice. The bulbs I forced this year were also forced last year. They were planted February 8 and the first flowers were cut the 30th of May. This year's work began December 27 by putting each bulb in a four-inch pot, using sandy loam without manure, and placing the bulb on top, pressing it down to hold it without any other covering. They were watered and then placed under the benches of the carnation house until the beginning of February. At that time those plants which had grown four inches were brought to light and again watered. Placing them close together on a bench near the light, a little water was given them from time to time, retarding the top growth and encouraging the root action as much as possible.

"My soil is rather of a heavy sandy loam, and in this the bulbs were planted; the depth of the bed being a little over four inches. The bulbs were scarcely covered at this time and this I find prevents the plants from damping off during the dull days when they have commenced to grow rapidly. By the middle of March each 
plant was tied separately to prevent its falling over. A light mulehing of stable manure was then put on and well watered.

"Three things I find necessary to suecessfully force the gladiolus:

"First-The pots must be well filled with roots before the plants are finally set out in the benehes.

"Second-The nearer the bulbs are to the surface the less liable the plants are to damp off.

"Third-The bulbs must be well ripened before using."

You will note the entirely different system used in the greenhouse or indoors. In this case you plant near the surface. In the open you must plant at least four inches deep.

UNNAMED VARIETIES.

These are very numerous. I think the better way is to get choice mixtures. They come cheaper and you get the different shades and colors. Different dealers I note advertise the Groff, the Child's, Lemoine and Burbank mixtures, and they are all fine and come cheaper than the named sorts.

SOME POPULAR KINDS.

Canary Bird is a large fine yellow flower.

Shakespeare is called one of the best. Flowers large on a long spike, creamy white, with delicate carmine rose tintings and quite a blotch on the lower divisions.

La Candeur is fine and large with strong spikes well lined with beautiful blooms, nearly white. 
Romulus is very early, dark red, with pure white blotches.

Isaac Buchanan is clear yellow.

John Bull is white.

Napoleon III is a bright scarlet flower striped with creamy white.

A good way is to get the finest mixtures. Mark the best when you take up the roots. Save the bulblets from them and keep them separate. Name them if you choose. Keep at it year after year and you will soon have quite a stock. If you wish entirely new ones save seed from the very choicest and begin at the foundation and develop something entirely new.

\section{CANNAS.}

There is a growing interest in these flowers. They make an imposing appearance in the garden. At first they were used largely for foliage effect. The leaves are large, and some deep green, some light green and others of bronze color. But great improvements have been made of late years so that now they are highly prized for their blossoms as well. They are not of much value as cut flowers, but for imposing effect of bloom and foliage they are not surpassed.

When you have a collection put the rankest growers in the rear. The Pillar of Fire is immense in growth and a fine bloomer. Plant next to this those of slower growth, then come down to the dwarfs and you have a stairway of beauty, rising till they reach the Pillar of Fire, which overlooks them all. 
They multiply rapidly. One root may have 15 or 20 divisions. You separate these and plant about the first of May or earlier perhaps, as it takes some time for them to come up. It is sometimes difficult to keep the roots. Of course being tropical plants, they never get ripe. They are always killed down by the frost and of course the roots are green. If they get too dry they do not like it, and if too wet they will rot. You must watch them and perhaps bring them out and air them on mild days in winter. They are much harder to keep than the dahlia, which you can treat as you would potatoes. I have received the latter when almost entirely dried up, but they would grow all right. Cannas should be planted four or five inches deep in very rich ground. Put them about 18 inches or two feet apart. They must have rich ground as they are rank feeders. If very dry you had better mulch heavily if you cannot water them.

RAISING FROM SEED.

This is an easy matter. Some will put seeds in a pot and start them early. I have planted, however, in the open in the latter part of April and had blooms of marvelous beauty and heavy roots the first year. Some were fully up to many of the named sorts. Some were fiery scarlet, others were red and gold, some yellow and highly freckled-in short there was a menagerie of beauty and a perfect surprise of loveliness.

The seeds are very hard. I brought water to the boiling point and then took it off a few moments to 
take off keen edge, then poured it on and stirred rapidly for several minutes; then covered them up and left them standing a day or two and had a beautiful stand. Soaking in quite warm water a few days and changing the water twice a day will do well and you take no risk of overheating. Plant about two inches deep in light fine soil.

The following are described by — \& Co., Tarrytown-on-the-Hudson, N. Y.:

Mrs. Kate Gray-This is an extraordinarily grand canna in every way. Flowers are of gigantic size, measuring six inches in diameter, much larger than Italia or any of the Italian varieties. The Italian varieties, in fact, are not to be compared with this variety in any way-size of flower, freedom of bloom, or substancethe flowers of this variety lasting as well as almost any of our leading standard sorts. In color, the flowers are very brilliant, deep orange, round and full, and are thrown high above the foliage, making them very showy and effective. It is one of the most effective bedders we have. It is a very free bloomer, and bears a large number of flowers on each spike. It is also a very strong grower, and would be valuable on account of its beautiful and luxuriant foliage alone, which is tropical in its luxuriance, much resembling the Abyssinian Banana; but added to this are its gigantic flowers, borne in large clusters, towering on large flower spikes high above the foliage, and produced in the greatest profusion. Notwithstanding its immense size, it is as free a bloomer as any of our best standard sorts. All who 
have seen it in our grounds the past summer unite in pronouncing it the finest thing in cannas sent out for a long time.

Pennsylvania-Another new, grand, giant-flowered variety, fully as large as Mrs. Kate Gray and an equally free and abundant bloomer, but entirely distinct in color, being a deep, rich scarlet.

Betsy Ross-We consider this the finest pink canna ever introduced. It is a fine, strong grower and an exceedingly free bloomer, flowers being borne on large, erect trusses, held well above the foliage.

Buttercup-Almost absolutely pure golden, or buttercup yellow-pure yellow except for the very faintest possible markings on the lower petal. Very free bloomer, producing large and handsomely formed flowers on large trusses, which are always bright and clean. This variety is valuable on account of its exceedingly bright color, and particularly so on account of its very dwarf habit, growing not over three feet high-about the same height as Pierson's Premier-giving us a first-class dwarf yellow sort, which has long been needed.

Black Beauty-By far the handsomest of all the dark-leaved cannas. While the flower is insignificant, the exceeding beauty of the foliage more than compensates for this, and whero foliage effect alone is desired, nothing richer and handsomer can be found. Foliage is large and massive, of the richest bronzy purple color, shaded with black, with beantifully crimped or undulating edges. Foliage is almost as rich and striking in color as a dracena. 
Pandora-A rich dark-leaved variety - as highly colored and as glossy as a dark-leaved dracena. Next to Black Beauty, the most beautiful dark-leaved variety. Besides its beautiful foliage, it is a large-flowered variety of the Italian type, with flowers as large as Italia or Austria, scarlet marked with orange,-almost the same color as Mrs. Kate Gray.

Tarrytown, the Finest of all Cannas-This variety sent out four years ago for the first time, was very highly recommended, but we are glad to state that it has exceeded our anticipations in every way; we believe we can justly claim it is the finest canna for bedding grown today. No variety approaches it for display. The flowers are large but its particular value lies in the earliness with which it blooms, the abundance of flowers produced, its branching habit, and the lengths of time the flowers remain after they open. Another point of superiority is the fact that the flowers are thrown well above the foliage, and the heads of bloom are held very evenly, and so freely produced that the foliage is almost hidden. One characteristic of this variety which largely gives it its value is its wonderful branching habit, two or three spikes of flowers being in bloom on the same stem at the same time, producing a mass of bloom. The flowers, which are an exceedingly brilliant carmine crimson, have decidedly more substance than any other variety, and last for an unusually long time. The stem carries no withered, dried-up flowers, but is always bright, clean and fresh. There is so much substance to the flowers that heavy wind and 
rain storms have no effect upon them, leaving them bright and fresh, when other varieties have been knocked to pieces. It is a fine, strong, healthy grower of moderate height. No variety compares with it in any way for a constant, continuous display; it is perfectly safe to say that it showed six times as many flowers for the same amount of space as any other variety in our fields. Wherever it was planted, it stood out prominently among the best. Many canua experts who have visited our trial grounds invariably pronounce Tarrytown unquestionably the finest of all bedding cannas introduced up to this time. It cannot be praised too highly. It is as much ahead of all other cannas today for bedding as Mme. Crozy was ahead of all its contemporaries at the time of its introduction. Notwithstanding the fact that this variety has been offered for four years, the demand for it last season exceeded the supply.

Rosemawr-A grand pink variety. Rich shade of soft rosy pink, slightly dappled with deep rose. One of the freest-blooming cannas that we have, either inside or out. Flowers are very large and of good shape, with broad, well-rounded petals, frequently two inches across and uncommonly thick and of good substance, and the trusses are enormous. Dwarf habit, averaging about three feet in height. A wonderfully fine acquisition; no up-to-date collection is complete without it. It occupies the front rank among cannas of any color.

NEWER AND SCARCER SORTS.

Improved Pillar of Fire-An exceedingly brilliant variety-fiery crimson scarlet. A giant of its class, 
growing six to seven feet high, and a very free and early bloomer. Invaluable for centres of beds.

Crimson Bedder-A grand bedding canna. Intense crimson scarlet, dazzling in the extreme. An exceedingly free bloomer, quite dwarf in habit and very bushy and when in flower makes a perfect blaze of color. Few if any of the newer cannas equal this variety for effectiveness as a bedder.

L. Patry-Orange salmon, showing a pinkish sheen on the older flowers-an entirely distinct color; very bright and effective. Large flower and truss. An exceedingly free bloomer.

Luray-A very fine new pink variety, with flowers and trusses of the largest size. Flowers are as large as Rosemawr, but are very much darker, being a dark rosepink. An exceedingly free bloomer, and a fine thing in every respect.

Martha Washington-A grand new pink canna with extra large flowers. Very deep, bright pink. Most of the flowers have five petals, which are very broad and long. Trusses are of the largest size, and are perfectly erect. A grand variety. Very distinct and very superior.

Michel Favrichon-An exceedingly free and early bloomer and a very strong grower. Flowers are exceedingly large and very showy; bright orange, slightly shading to carmine and dotted with carmine.

Philippe Rivoire-Bright scarlet, mottled and tinged with carmine, with a very narrow golden margin. Very 
handsome and distinet flower. Rather tall grower with beautiful foliage. Free bloomer.

Souv. de Mme. Nardy-A beautiful mottled variety -bright golden yellow, heavily spotted with the most intense scarlet. The variegation is similar to that of Florence Vaughan, but the colors are much deeper and brighter. It is entirely distinct : from Florence Vaughan and is one of the most beautiful variegated cannas ever raised. Tall grower.

Pres. Max Michelli-This is the finest and largest flowered of all the dark-leaved varieties. Bright orangescarlet, shaded earmine, with bright carmine splashings. Flowers are as large and fine as any of the greenleaved cannas. Dwarf grower.

Admiral Avellan-A fine dark-leaved canna. An exceedingly free and early blooming variety, being a mass of color all summer. Deep orange, much darker than J. D. Cabos. Fully as free a bloomer as Egandale and considerably taller.

Alphonse Bouvier-One of the earliest, showiest, and freest blooming varieties grown today. Tall grower; under good cultivation grows from seven to eight feet high. The heads of bloom are of the largest size, brilliant scarlet crimson; very effective.

Alsace-The only white variety; the nearest approach to a pure white canna yet introduced. Flowers at first are a light sulphur yellow, changing to a rich creamy white. Flowers are not so large as some, but it is an immense bloomer, being loaded with blossoms all through the season. 
Beaute de Poitevine-A fine dwarf, compact grower. Flowers are of good size, crimson scarlet, with no shading of any kind. A free bloomer, throwing up large trusses of bloom. Foliage is very distinct-glaucous green.

Egandale-This is a dwarf, very compact, freeblooming dark-leaved variety. Foliage is dark greenish maroon; flowers bright cherry. An exceedingly free bloomer, and a favorite sort.

F. Neuvessel-A fine dark-leaved variety; foliage is very handsome. Orange scarlet flowers, showing a pinkish tinge on the older blooms. Tall grower and very free bloomer.

Florence Vaughan - A very effective and showy variety. Flowers are of the largest size, brilliant yellow spotted with scarlet. This is the finest variety of its color and the standard spotted sort today.

Mlle. Berat-This is a pink canna of French origin. Dark carmine pink. Heads of bloom are held erect and well above the foliage. A showy, effective bedder. Tall grower and exceedingly free bloomer.

Mme. Crozy-Scarlet, with golden edge. This variety is the one that tended to popularize this beautiful class of plants, and is still considered very desirable.

Philadelphia-Exceedingly brilliant; a bright, glowing crimson, very rich and velvety. It is very early, very dwarf, and a very profuse bloomer. Extra good and extra desirable in every way.

President Cleveland-A fine, compact, vigorous grower, throwing up numerous flower spikes of im- 


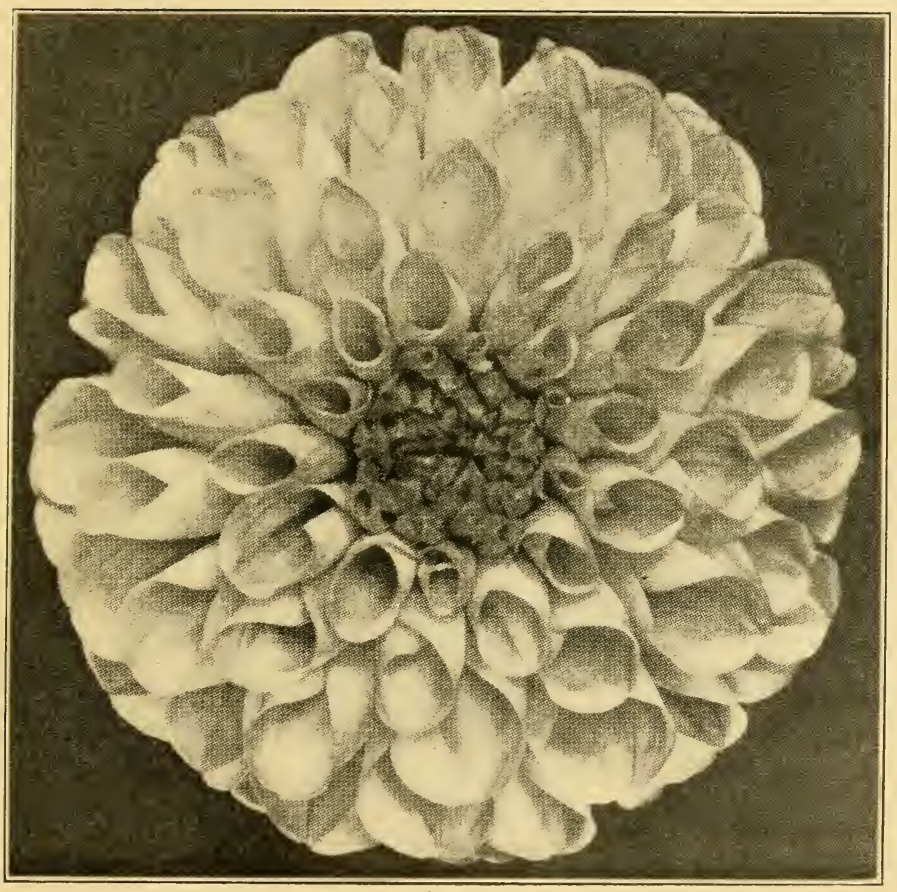

Mrs. ROOSEVELT IMHLIA, 

mense trusses and flowers of very large size. One of the showiest varieties. Color, bright orange scarlet-about the same shade as Robt. Christie.

Duke of Marlborough-Darkest of all cannas-very dark crimson. Very free bloomer and a tall, strong grower. Very desirable.

Sour. d'Antoine Crozy-This is a superb rariety in every respect, and is one of the rery finest that we have today. In color it is an intense, vivid scarlet, bordered with a narrow band of the deepest golden yellow, the yellow border intensifying the brilliancy of the scarlet. The effect of a group of these flowers in the sunlight is dazzling. It is an exceedingly free bloomer. The heads of bloom are very large, and the flowers are retained upon the spike more than an ordinary length of time. It grows about six feet high. Those who wish to have the best cannas should certainly have this variety.

\section{THE DAIILIA.}

When the procession of the earlier flowers, like the tulips, columbines, paeonies and roses have passed by, we need a companion to the glorious phlox which falls into the line and cheers us till frost comes.

Today is the 20th of October, and before my window are great masses of Dahlias in full bloom. They commenced in June. They give off an immense amount of cheer. They are easy to raise, and can be kept like potatoes through the winter.

The Dahlia, more, perhaps, than any other flower, shows the wonderful skill and patience of the florist. 
It was first discovered in Mexico by Baron Humbolt and was sent by him to the botanical gardens of Madrid. It was named Dahlia in honor of a noted botanist, Dahl. After its first introduction it seems to have dropped out of sight. It was reintroduced into Holland, the land of flowers, in 1804. It was single at first and I suppose there were almost countless efforts made to improve it and finally after long experiments a double form rewarded the florist. Then improvements followed thick and fast until we have the almost infinite varieties of form and color. Almost every shade but the blue has been produced. There is growing in Mexico the Dahlia Excelsa, which grows 30 feet high, covered with a profusion of bloom. Dahlia Imperialis is a distinct species growing 10 to 15 feet high with fine branching, treelike form, producing in the fall pure white drooping, lilylike flowers three inches in diameter. Of course these last named are too tender for our northern climate, and the seasons are not long enough for their development.

A few years ago there was a decline in the demand for this flower. But as prosperity returned and the love of flowers has grown, a need was manifest for a flower which would reach from the paeony to the time of frost and so the want grew and the Dahlia grew to mateh it; till now one man in New Jersey has 80 acres and the flowers were sold by one firm in Philadelphia.

Our small cities and country towns are very slow to take up things of merit. Flowers may be ever so beau- 
tiful, but if they are not roses or carnations from the greenhouse there is little call for them, while the larger cities appreciate things on their merit.

For cut flowers some of the finer forms are of exquisite beauty and the marvelous variety of shape and color make them all that we can ask for.

\section{PROPAGATION.}

There are four methods. Division of roots, by cuttings, by grafting, and by seeds. Increasing by cuttings and grafting is done mostly in greenhouses. The other two processes can be used by the amateur, for they are very simple.

One day I was in the store of a florist in Omaha and a lady asked: "Why won't my Dahlias grow. I separated the roots and planted the tubers; but not more than a fourth grew at all." 'The florist replied, "Were you eareful to have a bud on every root?"

"No; I never thought it necessary."

"Things can't grow without a.head," was the reply. Now a large paeony root, broken off near the crown forming a perfect tuber, will take a year to put a head on itself; but the dahlia cannot do this and so must have a head to begin with. Note this then: in dividing your clumps have a bud with every tuber and if some tubers have no eyes leave them to help out those that have, thereby giving it extra force. Take up your roots in the fall before the hard freezes or frosts come on. Dry them and store them in a cool cellar where they will not freeze. If there is danger of the 
frost creeping in, take a box, line it with paper, wrap up your roots in paper and carefully'store them away. Throw loose paper on the top and put some old blanket over them.

They should be planted as early in the spring as it will do, about the first of May. Put them in about four inches deep.

They are rank feeders and do best on the richest ground. If you cannot water them thoroughly, then irrigate with the hoe, by giving the best of cultivation.

Dahlias love the sun and cannot thrive in the shade, so give them a good chance.

\section{SUPPORTS.}

Usually frames are made.for them, but for extensive cultivation this is not feasible. Instead, they are severely trimmed. When the branches appear cut them back as you would in planting a young apple tree. This makes them grow more stocky. I find this system works well where they stand in exposed places. They adjust themselves to the winds like a tree out in the pasture. But if they are planted rather close in secluded places the stems will be weak and they. must have supports.

\section{VARIETIES.}

There are two general divisions, the single and double, and these again are subdivided.

The doubles are grouped in sections something like the following:

The Cactus-These have peculiar petals quilled and 


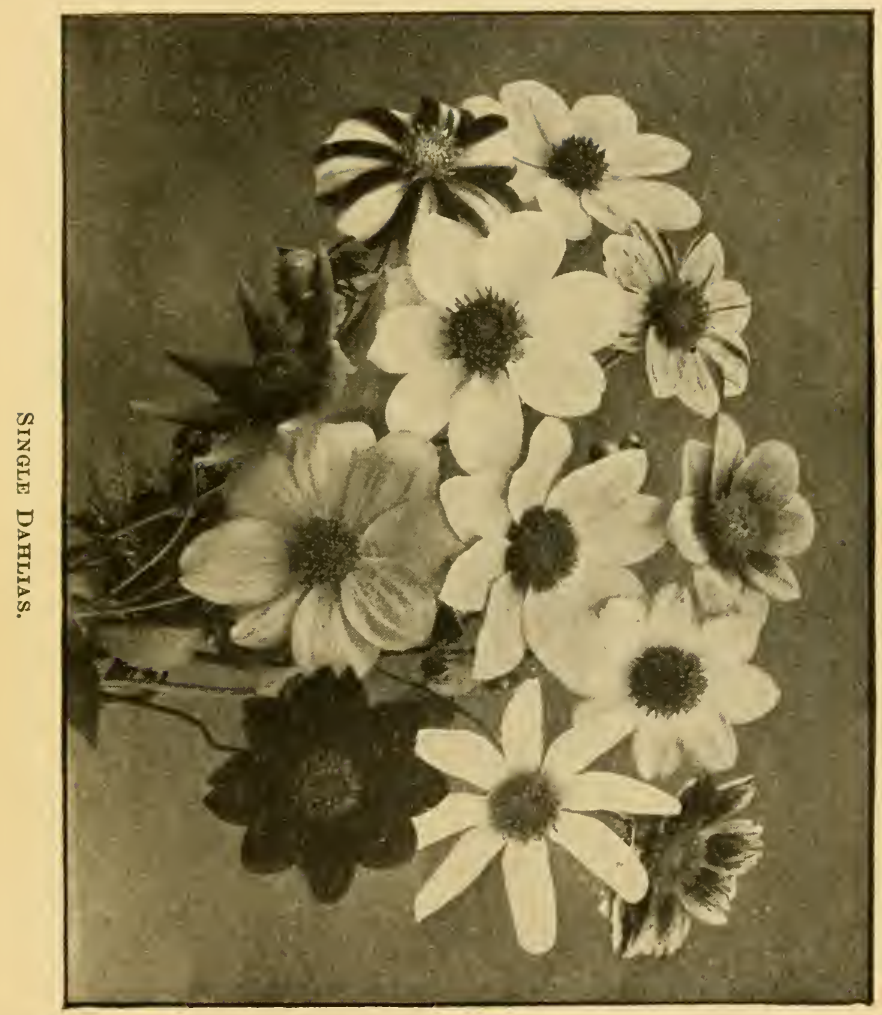




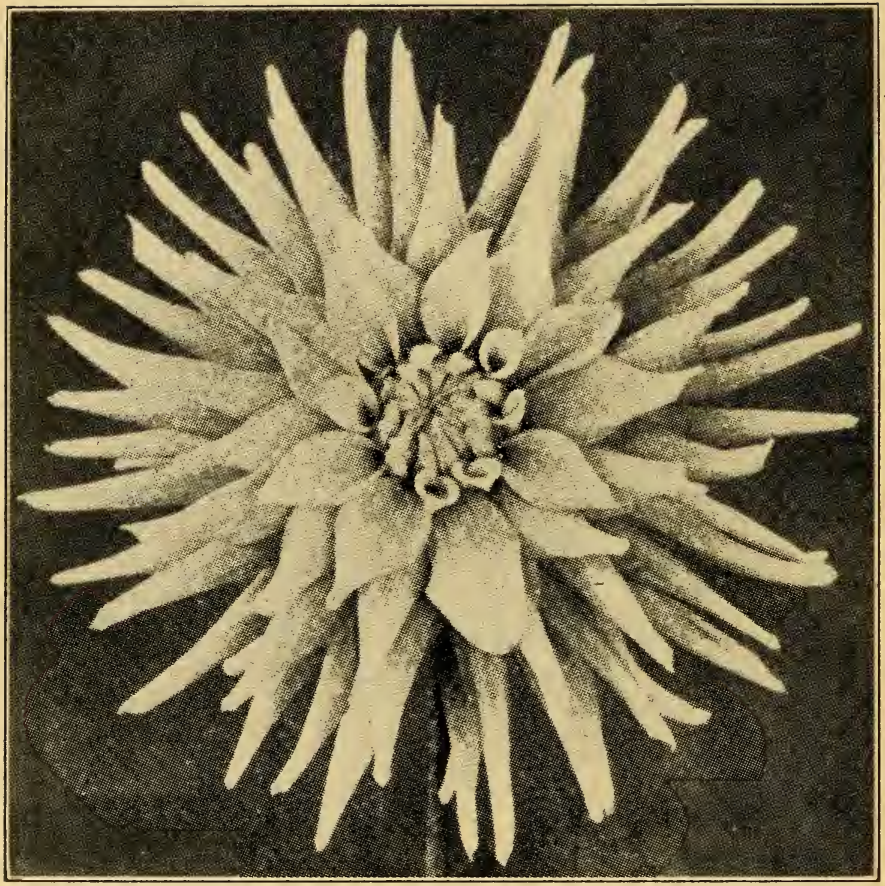

Cactus Dahlia. 
twisted, having a shape entirely unique and different from anything else. I give a few of the leading varicties:

Alpha is mainly white, sprinkled with purple, crimson and lilac.

Beatrice is deep rose color, with long pointed petals.

Cinderella is beautiful flame-like crimson.

Gabriel is described by Peacock as follows: "The ground color is soft velvety crimson, having a faint cinnamon liue at the bases of the florets. The upper part of each floret for about half its length is snow white. A very showy flower."

Henry F. Mitchell is very large and irregular in form with colors varying from soft yellow to intense orange red.

Juarezi is the mother of the eactus group. It is deep scarlet, with long, narrow, twisted petals.

Lady Penzance is pure yellow, with long twisted petals.

Miss A. Nightingale is deep yellow, tipped red and semi-double.

Matchless is a dwarf, strong and vigorous, of branching habit, flowers large, rich, varnished crimson, overlaid with maroon. Quite early, and a wholesale bloomer.

Sea Queen is purplish, with a bluish sheen.

Spitfire is scarlet, with clawlike petals.

I give only a few of the 120 mentioned by Mr. Peacock-just enough to give an idea of the character of 
the family. If a man has 80 acres, as he has, in Dahlias, he can take care of the whole group, but the rest of us with small spaces must be content with a few samples.

Then there is an extended list of the

DECORATIVE DAHLIAS.

These have large flowers and are very imposing in appearance and $I$ have watched them with much interest.

Over forty-five kinds are named and these are not all; for new ones have been added all along.

Black Beauty is a fine maroon. It is of such deep color as to be almost black.

Clifford W. Burton has large golden flowers. I have watched them unfolding till late in October. They are fine and symmetrical, like a large chrysanthemum. In color bright, clear yellow and the flowers are continuous and very large.

Maid of Kent is cherry red, tipped with white.

Mrs. Roosevelt is a large flower of superior beauty. The blossoms are double-six inches or more across. The color is delicate bluish white.

William Agnew is a great favorite. Flower seven inches across, full center, fine form, color clear shade of intense red.

\section{SHOW DAHLIAS.}

These are of compact ball shape. Some of them are wonderful in their exquisite tinting and shadings. It would not seem possible that so much delicate beauty 


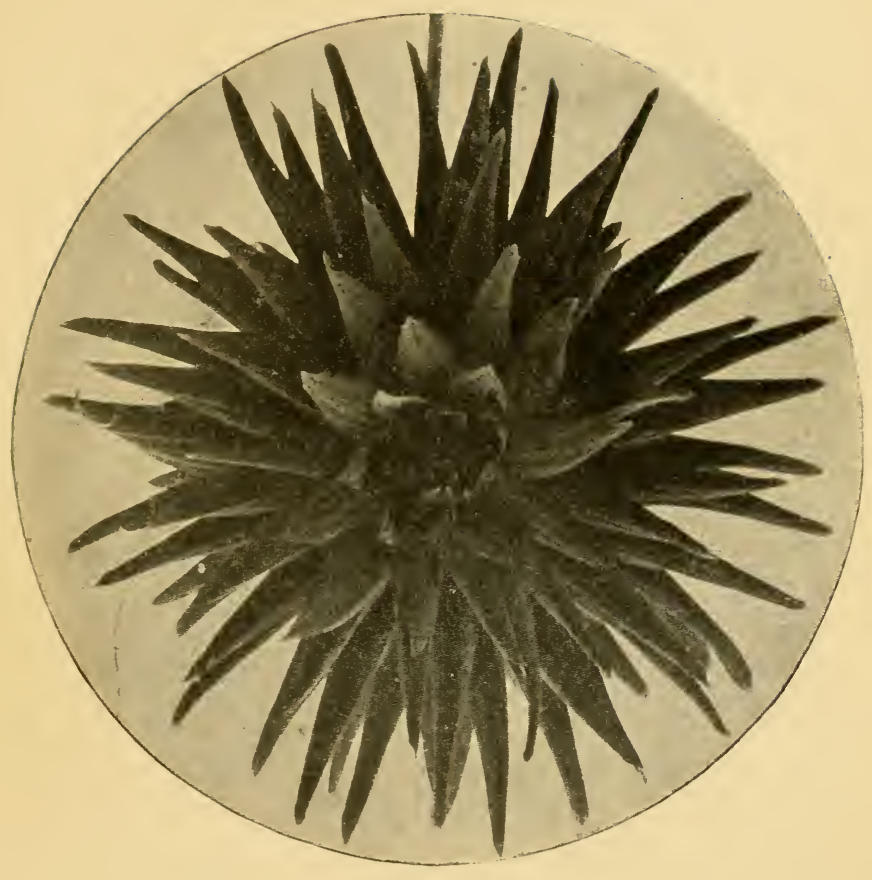

Mars-Bright, Rich Cactus Dahlia. 


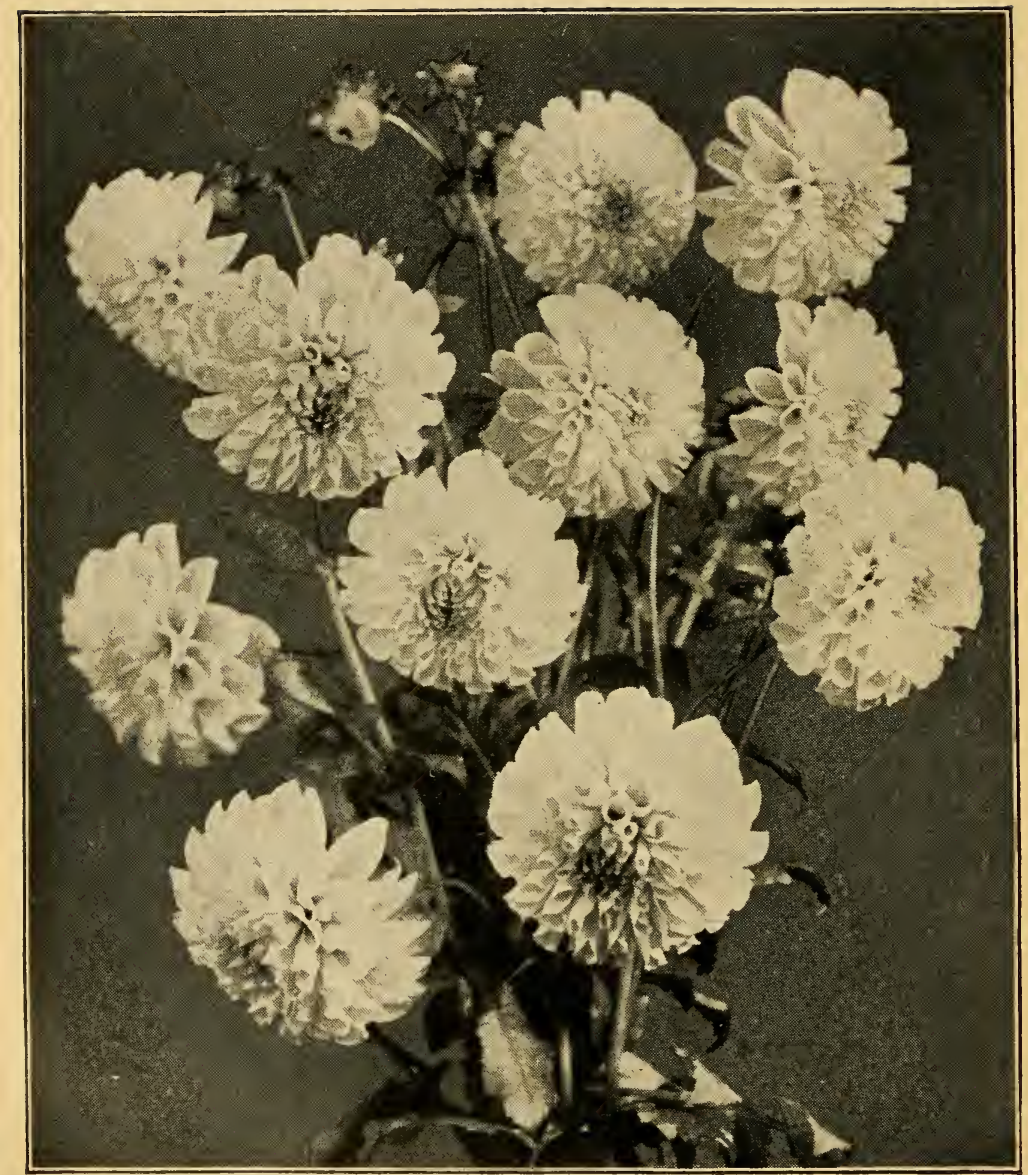

Decorative Dahlias. 
could be erowded into a ball of loveliness. About 75 kinds are given with their varying shades. We can give only a few of them. On our own grounds these have been the most satisfaetory of all; though some kinds have been sent out too insignificant in size and so dull in color as to have no real merit and they might as well be discarded.

Aleta is fine, light pink in color, flowers in balls, moulded in perfect form. It is one of the first to bloom and after the 20th of October I have seen it loaded with a profusion of flowers. It scems very conscientious, as if it had to be done.

Beauty is snow white and of perfect form.

Golden Canary is clear yellow of very fine shape, a perfect flower and profuse bloomer.

Honest John is brilliant maroon, richly shaded and often mottled with black.

Queen Victoria is one of our best golden ones.

Storm King is new, a symmetrical white flower. It is in great demand as a cut flower.

\section{FANCY DAHLIAS.}

This group is set aside as another class, something like the last mentioned only on a larger scale. Many of them are almost indescribable in their beauty. Some have marvelous edgings, tintings and touches of remarkable shadings. Some are variegated with exquisite blendings of colors.

American Flag has ground color of pure white, with 
a border of deep red and sometimes bars of red striping with the white.

Elegans is rosy red, banded white.

Olympia is one of the finest of this attractive group. It is six inches in diameter. The color is rose pink, striped and edged with crimson.

About 40 kinds are given in this group.

\section{POMPON DAIILIAS.}

These are of dwarfish habits, profuse bloomers and have a rich variety of colors.

Then we have

THE DWARF CLASS.

These are used for borders.

Then there comes the Pigmy or Tom Thumb family.

Then there is a very large family of Single Dahlias. Another class are called Orchid Flowers.

STILL ANOTHER CLASS.

are called collarette, because the flowers all wear collars.

KEEPING CUT FLOWERS.

Nearly the same rules must be followed as in the preparation of paeony blooms for market.

Remove all the neighboring buds and side shoots. Leave the foliage on the stem to which the flower belongs, then put the stem in water and allow it to ab- 


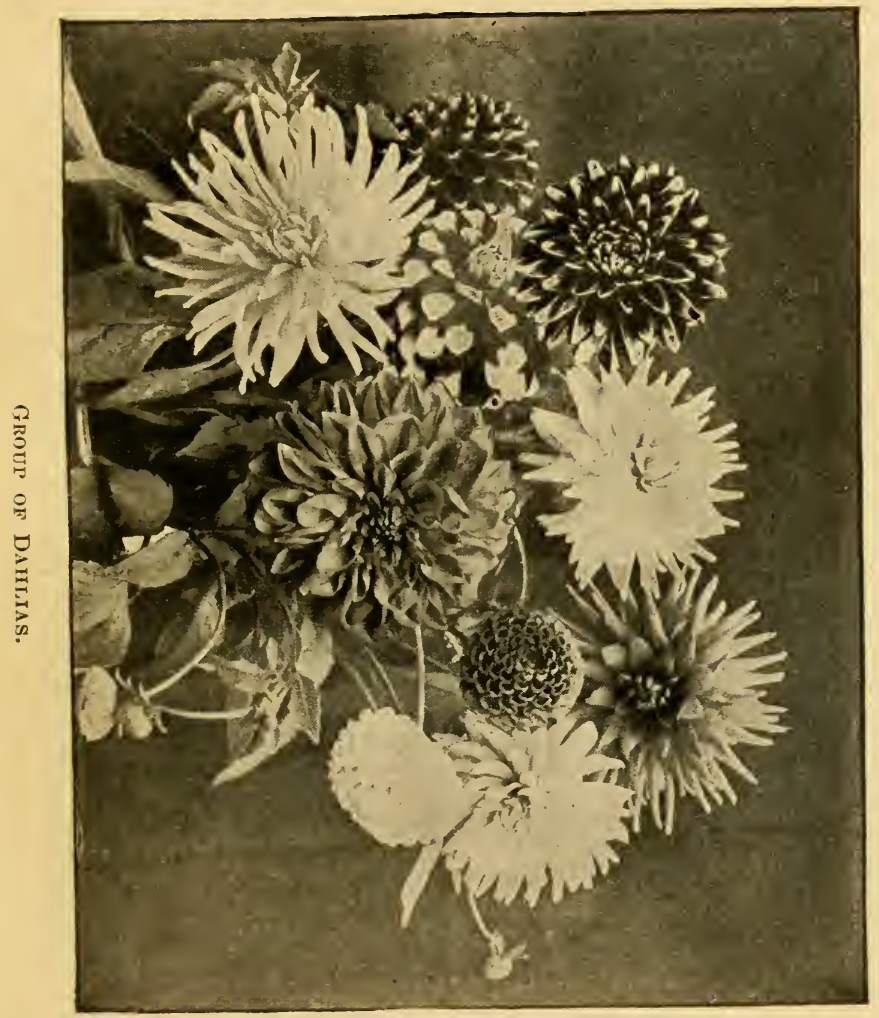




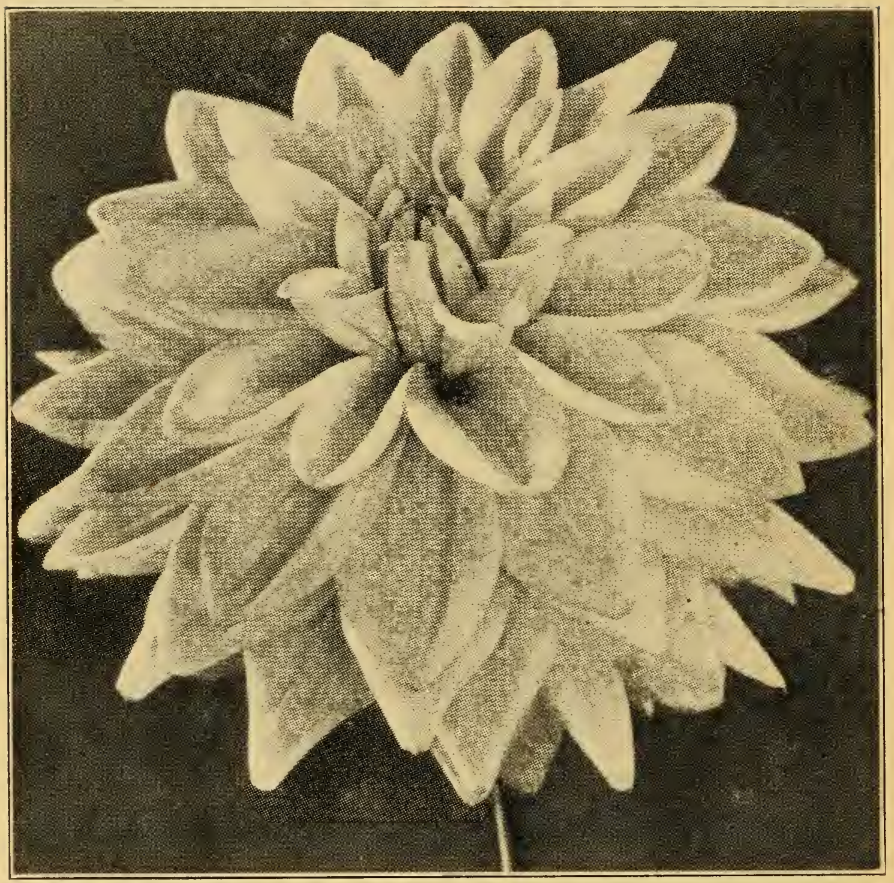

Decorative Dahlia. 
sorb its fill. You can then pack and ship or put them on exhibition.

There is a great future for these flowers. The amateur has a wide field in sowing seeds, and watching new developments. In fact it is hard to keep up with the pace this flower has set for us.

We prefer perennials if possible. We plant them and they stay planted, but the ease with which these are propagated, the immense returns they give for good cultivation, and the little care required in carrying the roots over will make them favorites. They are rank feeders and require plenty of room.

In planting, put the largest and strongest in the baekground. Then those of less growth. Then put the Tom Thumbs at the front, so you can take in the whole at a glanee.

A PARTING WORD TO TIIE PIONEERS.

Brothers, we have worked hard in carving out a new empire. We are of the West and a part of it. We have seen it grow from childhood to stalwart manhood and have done what we could to make it grow. We are now on the down hill way, and we cannot climb back again. We have earned the right to be rich and to enjoy ourselves. But there are treasures outside of gold and stocks and bonds. $\mathrm{He}$ is the rich man who is contented with a pleasant home and is out of debt. I note that often the farmer leaves his home and moves into town where he is often restless and dissatisfied. If he stayed by his farm to the last and beautified and 
adorned it, he would keep himself young among his flowers and life would have an enjoyment he cannot find on a narrow town lot. For myself I have been a hardworking man. I began life in Minnesota in $185 \%$. I was there when the state was born. I am 72 years of age, but I cannot feel that I am growing old. I seem standing on the borders of eternal youth. True, my feet move more slowly and I cannot match the full vigor of my prime, but the soul is young. I am going towards the sunset, towards the "golden gate"; but it is not a dreary or wintry way.

Often have you watched the glowing splendors of the evening, when the stately clouds like heaven's own sentinels escort the retiring day to his chambers in the west. What brush can portray those inspiring displays; what pen can describe the robing of the clouds. It is as if the choicest gems of earth were melted together and then piled up in mountain vastness. There are great masses of opal, amethyst and gold, and beyond the fields of sapphire the scene is glory. set on fire, and the vast procession trailing its splendors seems as if escorting a conquering soul into the eternal joy.

$\mathrm{No}$, this is not old age; it is but the promise of another morning.

"We all do fade as a leaf." But how do the leaves fade? Go into some of our mountains after the touch of the frost and the whole landscape is a splendid garden robed in indescribable loveliness. What a rich blending of color. The gold of the maples, the purple 
of the oak and cherry and all the shades and tints of the other trees of the forest give us such a picture as only gifted nature herself can paint.

And yet this resplendent golden summer of the year is called the symbol of death.

We have much to do in adding to the pleasure and happiness of our declining years. As the day is closed by the resplendent curtains of the clouds, so we can make the hither shore a promise and a prophecy of what lies beyond. You can gloomily wait by the river in a barren land or you can wait in fields Elysian amid the fragrance and beauty of the choicest tributes which earth can cast at your feet. You are already heir of all things, and have had your coronation here of "riches and honor." Hovering over and around you are the choice tributes of the infinite love. Why not reach out and take them? You are sons of a king; better be princes than beggars. Time is the porch of eternity. Earth is preparatory to heaven. We strive to have our souls in accord with the peace and the purity, the harmony and sweetness of the heavenly state. Why not educate also for the beauty of heaven?

Stand on the threshold of the future. Tisten to the salutations of the universe, "All things are yours." Think of a home whose foundations are gems, whose dome is sapphire, whose walls are jasper, with gates of pearl, with opal sea flashing in the supernal brightness, with streets gold paved, with a mansion built by the hand which hung those mantles on the suns, which touched so deftly the petals of the flower, which put those tints on the clouds. 
Then look out on the vastness, on the boundless abysses of glory, where the stars are the bouquets of God, where the infinite fields are gardens of flowers sprinkled with stars of various hwes, and is there nothing to be learned here of the beauty of our Lord?

So fill the closing days with cheer. Let beauty leap from your brain and fall from your hands. Use your creative powers. Show your birthright by making the earth smile with gladness. Be yourself a creator of the beautiful. Call forms of loveliness from the sunbeam, from the rainbow, which is ready to melt and dissolve in beautiful bloom for your enjoyment. It is wrong to let God's great unseen processions of beauty pass by without a recognition.

It is wrong to take a piece of God's fair earth and let it go to weeds or simply raise from it something to fced the stomach, and raise nothing for the soul.

There is that patient wife, mother of your children. What a woman she has been; how heroic she was when you were starting in life; how meager the fare; how she suffered with the cold. More than once tears came to your eyes as vou thought of her privations. Now the battle is won, and to her soul has come a great longing for the beautiful. No queen more worthy than she. You can plant trees which will nod her welcome, you can have a soft carpet of green for her weary feet, you can plant flowers which will rise up and call her blessed, which all summer will put themselves on dress parade for her and worship her with their incense. Why not have a little pleasure in your old age? 
Again let the farmer keep his soul and his speceh clean. When I was a boy and men used to change work in threshing time it was awful. They seemed to vie with each other in using the foulest language and before the boys at that, and as the result many of the sons grew up vile and debased and lived in the basement rather than in the upper story of farming.

The farmer works with God. The one furnishing the capital, the other the labor, and thus the world is fed. He of all men lives the nearest to God. And when he receives his warranty deed from Him and from the United States government he is under the highest obligation to make the most of himself, of his family and of his farm. He should see that his children are brought up elean and not weakened by debasing habits. Surroundings have much to do in the development of character. I would much rather children would be brought up in beautiful grounds where beauty and purity would greet them everywhere than in a yard which was the home of pigs and a hospital for sick machinery.

There is no farm in the great Northwest which cannot be greatly improved and made homelike. A man should have an ambition to make the most possible of his home. It should not be an eyesore and a plague spot. It should match the greenness of the fields, the beauty of the prairie and forest and the repose of the waters and all the loveliness of nature, and so, my brother, you will fix up, won't you? 


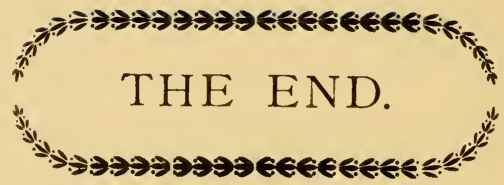





1 H.

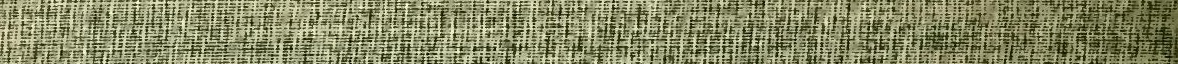
H(2) (15

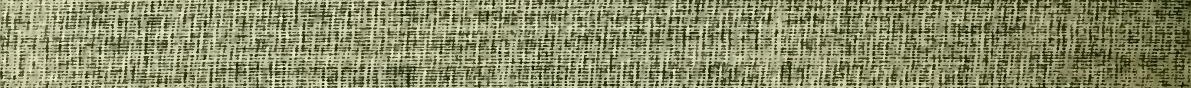

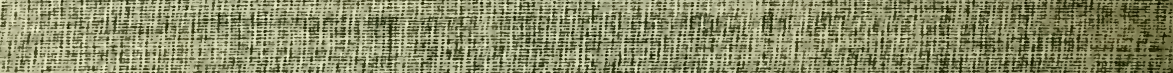
Hat

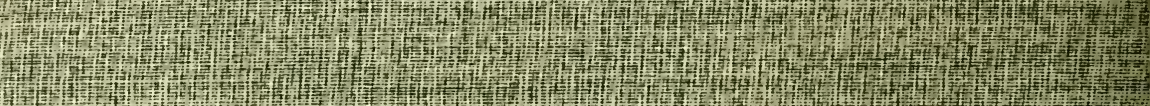

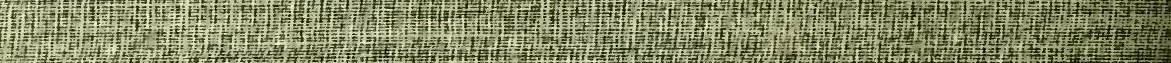

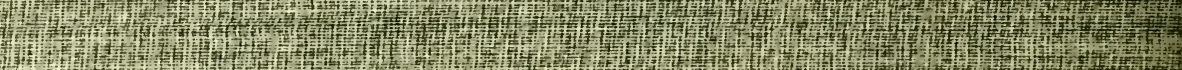
(2)

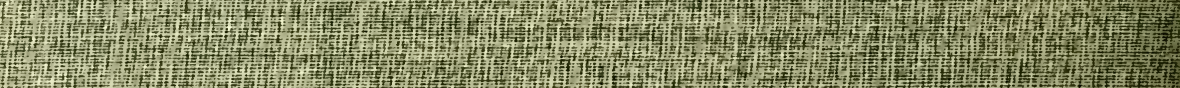
(1) (1)

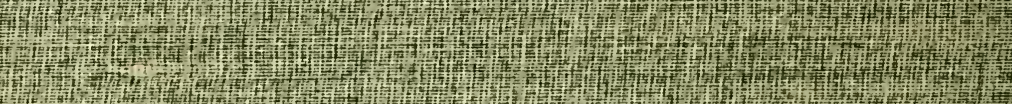

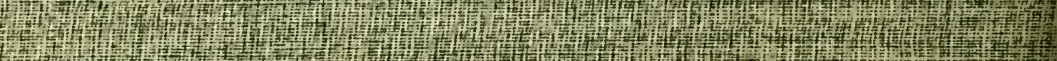

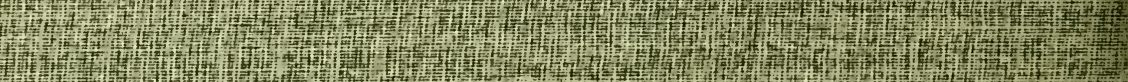
Th:

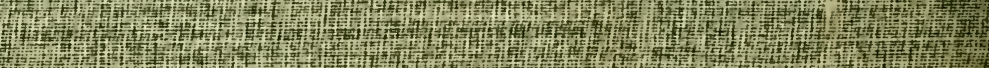
[1:

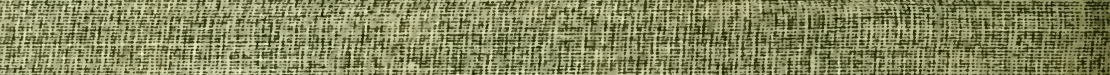
4:

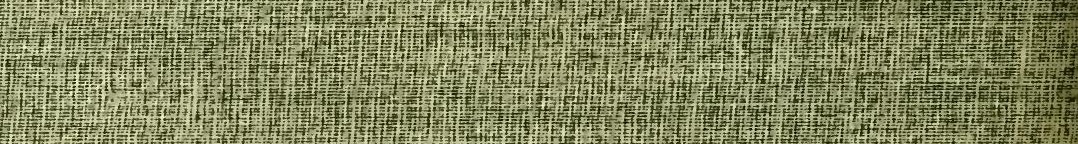
(2)

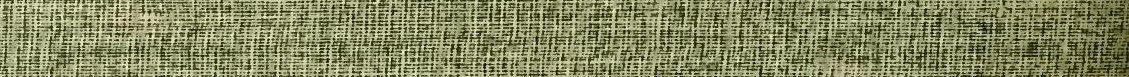
H(1) 1)

\section{Hol:} (1) (1)

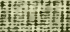
4+174) H.

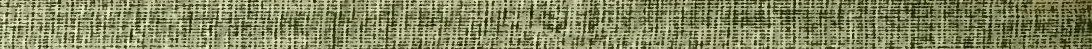

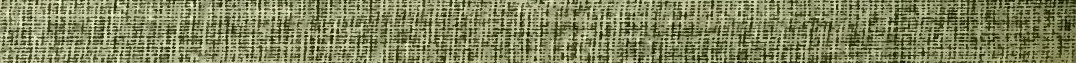

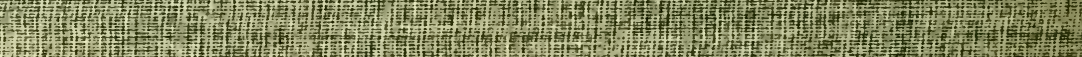

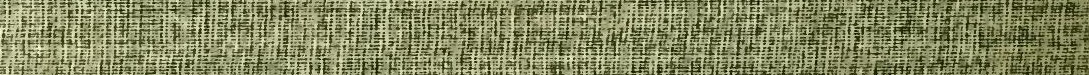
H 